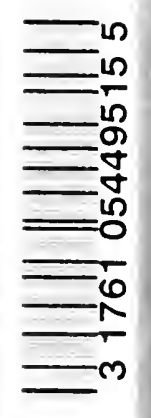

GN 440

. 2

$\mathrm{H}_{34}$ 



\section{THE OUTRIGGERS OF INDONESIAN CANOES.}

A. C. HADDON.

PUBLISHED BY THE

Bropaf entbropofogical Instifute of Breat doritain and Jrefond, 50, GREAT RUSSELL STREET, LONDON, W.C. 1. 


\title{
THE OUTRIGGERS OF INDONESIAN CANOES.
}

\author{
By A. C. Haddon.
}

\section{CONTEN'TS.}

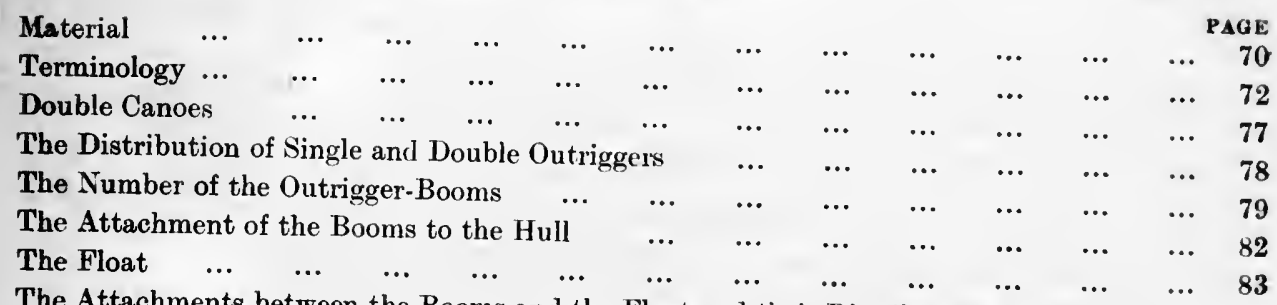

The Attachments between the Booms and the Float and their Distribution :A.-Direct :-

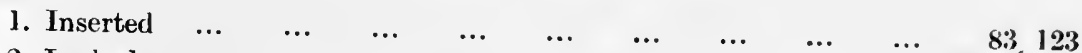

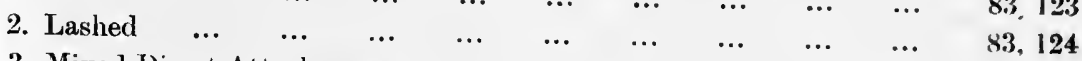

B.-Indirect :-

$\begin{array}{lllllllll}\text { 3. Mixed Direct Attachment } & \ldots & \ldots & \ldots & \ldots & \ldots & \ldots & \ldots & 84\end{array}$

(a) Attachment inserted into the Float :-
1. Stick
2. Rod
... $\cdots$
$\begin{array}{llll}\cdots & \cdots & \ldots & \ldots\end{array}$
84,125
3. Spike
4. Y-shaped Stick
5. Board
6. Balinese

(b) Attachment tied to the Float :-

$\begin{array}{lllllllll}\text { 1. Moluccan } & \ldots & \ldots & \ldots & \ldots & \ldots & \ldots & \ldots & \mathbf{8 9}, 129 \\ \text { 2. Halmalieran } & \ldots & \ldots & \ldots & \ldots & \ldots & \ldots & \ldots & 90,129\end{array}$

C.-Mixed Attachments :-

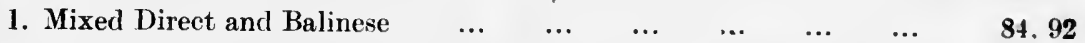

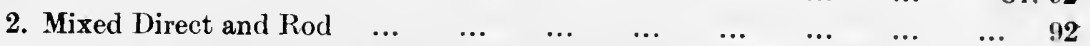

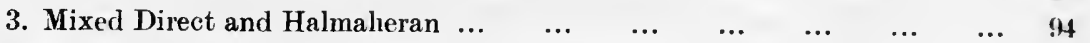

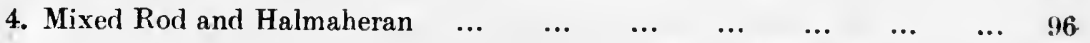

Notes on the Characteristic Outrigger Canoes of the Main Districts of Indonesia $\quad \ldots \quad \ldots \quad \ldots$

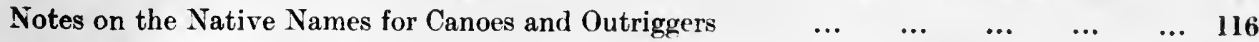

$\begin{array}{llllllllllllll}\text { General Conclusions } \ldots & \ldots & \ldots & \ldots & \ldots & \ldots & \ldots & \ldots & \ldots & \ldots & \ldots & 119\end{array}$

$\begin{array}{lllllllllllllll}\text { Bibliography } & \ldots & \ldots & \ldots & \ldots & \ldots & \ldots & \ldots & \ldots & \ldots & \ldots & \ldots & \ldots & 131\end{array}$

For several years I have been accumulating material dealing with the outrigger canoes of Indonesia, of which I now present a brief and general account, though I am fully aware of the imperfection of my data. Much more remains to be done by observations in the field, by a more exhaustive treatment of the literature on the subject, and by a study of photographs in the libraries of certain learned societies 
and museums, as well as of specimens preserved in numerous museums in various parts of the world. I hope, however, that this essay will help towards a more systematic consideration of the details of construction and of the problems of cultural distribution.

\section{MATERIAL.}

A word of caution is necessary with regard to the available data. A photograph, or an illustration made from a photograph, is good evidence that a certain form was then present in a given spot, but it is not conclusive that it is the usual or common form there, as any canoe may be a chance visitor. It is only when a photograph shows numerous examples of the same type that it becomes authoritative, or when different photographs agree in this respect. Of far greater value is the explicit statement of a traveller, and $I$ have endeavoured in all cases to record such statements. In drawings or sketches made by travellers a great deal depends on the skill of the draughtsman, his keenness of eyesight, and his knowledge of the details of construction. The unsatisfactory character of illustrations holds good for models, except that the common type is far more likely to be represented. But a further source of error awaits one. The model may be carelessly made and certain details may be slurred over or even wrongly constructed to save trouble. On the other hand, the models as a rule seem to be made by those thoroughly conversant with the vessels, and probably, in many cases, are made by those who actually build boats. The technical skill in model-making which is characteristic of these peoples, and the pride of the artificer, however, give one confidence in accepting models as trustworthy, even though the various parts may not be made exact as regards their relative proportions. Bearing in mind these limitations, I have not shrunk from accepting models as good evidence. In a considerable number of cases the written descriptions by travellers are far from satisfactory, as they often do not appreciate those details which are of interest to a specialist ; frequently no description at all is vouchsafed, and we have then to rely solely on any illustration that may be supplied.

Several of the following museums are referred to by the names of the towns in which they are situated :-

Amsterdam, Koninklijk Zoologisch Genootschap. Ethnographical Museum of the Natura Artis Magistra.

British Museum, London.

Cambridge, Museum of Archæology and Ethnology.

Edinburgh, Museum of Science and Art.

Halifax, Bankfield Museum.

Horniman Museum, Forest Hill, London, S.E.

Leiden, Rijks Ethnographisch Museum.

Oxford, Pitt-Rivers Museum.

Rotterdam, Ethnologisch en Maritiem Museum.

Salem (Mass., U.S.A.), Peabody Museum. 


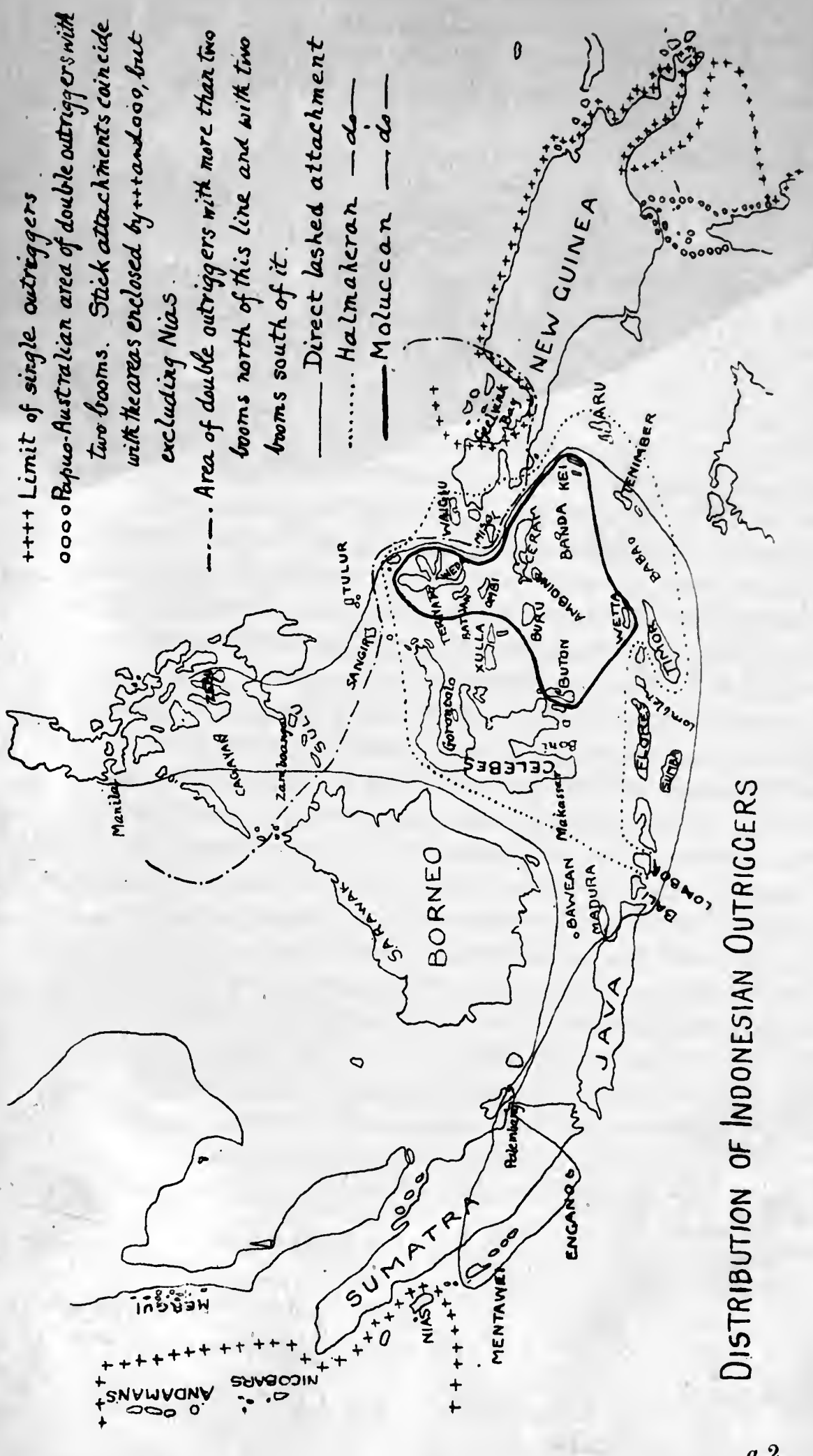


I take this opportunity of thanking various friends and colleagues who have helped me with information, and would more particularly like to mention Henry Balfour, Ivor H. Evans, Dr. G. Friederici, Dr. F. H. H. Guillemard, Lawrence W. Jenkins, Dr. H. H. Juynboll, H. Ling Roth.

For convenience of reference I shall, as a general rule, mention the several islands and places in the following order:-

Andamans. Nicobars. Nias, Mentawei Islands, and Engano (islands to the west of Sumatra). Sumatra: Palembang (in the south-east of Sumatra). Java. Madura. Bawean Islands (north of Madura). The Lesser Sunda Islands (Bali to Tenimber): Bali ; Lombok; Sumbawa ; Sumba (Sandalwood Island); Savu ; Flores ; Solor ; Lomblen ; Ombai (Allor) ; Timor ; Rotti ; Wetta (Wettér or Eetar) ; Serwatti ; Baba (Babber) ; Tenimber (Tanimbar) or Timor Laut (Timorlao) Islands. Kei (Ke) Islands. Aru Islands. The Moluccas (Banda to Halmahera): Banda ; Buru; Amblau; Amboina (Ambon); The Uliasser Islands: Haruku, Saparua and Nusa Laut; Ceram (Seran); Ceram Laut; Goram; Misol ; Obi (Ombi) ; Batjan; Tidor ; Ternate ; Halmähera (Gilolo): Weda Bay (the southern Gulf of Halmahera), Ake Selaka, Tobelo, and Galela (in the north of Halmahera). Xulla (Sulla) Islands. Butong (Butung). Salaier. Celebes: Makassar and Gowa (Goa), Gulf of Boni (the southern Gulf of Celebes), Tontoli (Toli-Toli, north-west Celebes), Minahassa (the north-east point of Celebes) with the towns of Kema and Menado, and the island of Limbe. Banka. Talisse. Talaut Islands (including the large island of Sangir). Tulur (Tulaur or Salibabu) Islands. Nanusa Islands. Sulu Archipelago. Philippines: Mindanao (Zamboanga at its south-west point), the Gagayanes (Cagayan) group, Zebu (Cebu), and Manila. Borneo : Sarawak, a raj on the north coast. North-west area of New Guinea: Skroë on the south and Sëkar on the north side of the Onin Peninsula; Waigiu (Waigeu); Saonek (an islet off the south shore of Waigiu); Sorong (a village just south of the extreme north-west point of New Guinea). Geelvink Bay. (See Map, p. 71.)

\section{Terminology.}

To avoid ambiguity I propose to adopt the following terms as here defined :-

The outrigger is a balancing apparatus that extends transversely across the hull of the canoe; the transverse poles of an outrigger are outrigger-booms (or simply booms), their free extremities may be attached directly to the float, ${ }^{1}$ or indirectly by various methods ; in all cases this is spoken of as the attachment. Various methods of indirect attachment will be sufficiently described in the course of this paper. They consist in the main of bent ratan in the Moluccan attachment, or of a stick or sticks, a rod, or of a variously shaped piece of wood, the outrigger-spar or attachment-spar

1 Frequently authors speak of the float as an " outrigger." 
(or simply spar). A thin spar, bracing spar, may pass from the attachment-spar (Fig. 2 D) or sticks (p. 126) to the boom.

There are outriggers in which one or more of the booms may have one kind of attachment and the other or others another kind; these may be termed mixed attachments. Cases are known to me, but not in Indonesia, where two kinds of attachment are employed on the same boom; this may be called a complex attachment.

In many outriggers there are one or more poles connecting the booms and usually lashed above them, but sometimes beneath them. These may be termed longitudinal spars, as they are longitudinal to, that is, parallel with, the length of the canoe, though transverse as regards the length of the booms themselves. They might therefore with justice be termed " transverse spars," but as the booms themselves are transverse as regard to the canoe and they are at right angles to the lie of the booms, it seems preferable to adhere to my former term. Sometimes there is a spar running more or less midway between the hull and the attachments - this may be termed the central longitudinal spar; the outer and inner longitudinal spars run respectively immediately on the outer and inner aspects of the attachment (Figs. 16 B, 17). In Micronesia a spar may pass diagonally from the hull to the end of the outrigger apparatus-this I term a stay spar.

Boom-prolongation.- This somewhat cumbersome term may be applied to a type of boom that appears to be confined to the East Java-Lombok area. The boom proper is short and thick, but a thinner spar is attached to it, the free end of which is either inserted into or lashed to the float or connected with it by means of a rodattachment. In small models of canoes from this area the prolongation is inserted into the boom, but the exact method of the junction in actual vessels has been described only in the case of the sedek, and the published illustrations known to me are not clear on this point. It may be suggested that the boom was made thick in order to strengthen the hull, but in that case it would obviously be too heavy to form an efficient outrigger ; to remedy this the projecting portions might be thinned down (which possibly may occur) or a more slender spar of wood or bamboo might be fixed on to it. The sedek of the Balinese attachment (p. 88) is thus merely one form of a boom-prolongation.

Occasionally there is a central outrigger-boom which is lashed to the various longitudinal spars but is not connected with the float by means of a regular attachment, though it may be tied to it by means of a long lashing - this may be termed a false-boom. Occasionally, outside our area, more than one false-boom may occur.

There may be above a boom another spar which varies greatly in length, sometimes being as long as the boom itself, in which case it might be regarded as a boom, thus giving rise to an accessory or double boom parallel to the boom proper; but in order to make the term applicable to all its variations, I prefer to describe it as a boom-spar. A boom-spar, one end of which rests on the roof of a shelter of a Mentawei 
war-vessel, knabat bogolu (Fig. 1), is figured by Rosenberg (1888, Pl. XVIII, Fig. 9). Baessler (Pl. VIII, Fig. 4) gives a drawing of a model of a sailing canoe from Wetta

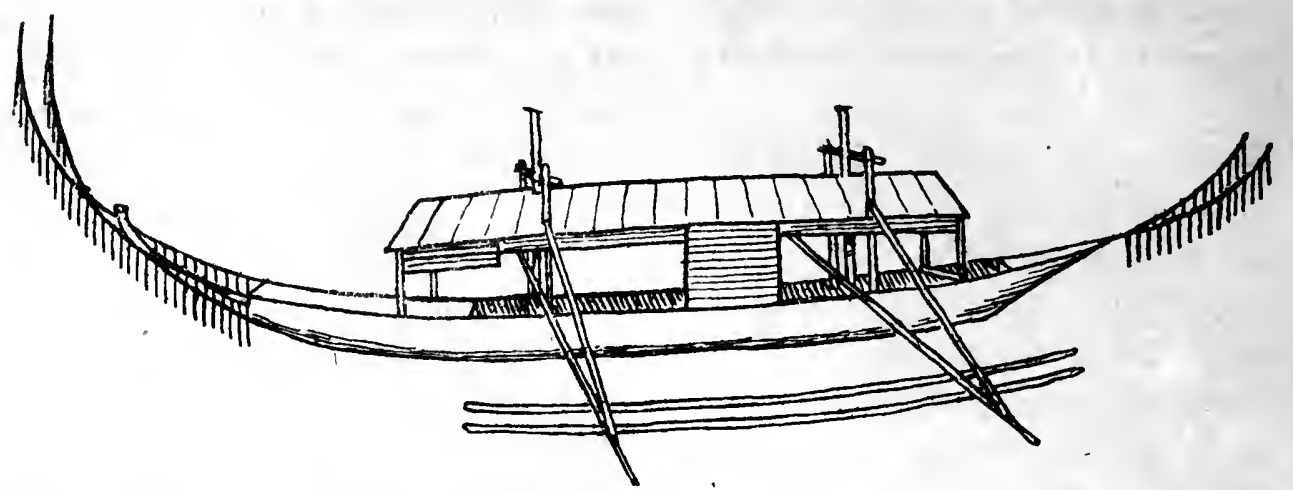

FIG. 1.-MODEL OF A WAR VESSEL, knabat bogolu, MENTAWEI ISLANDS (AFTER ROSENBERG, 1888). THE RIGGING OF THE VESSEL IS OMITTED.

A

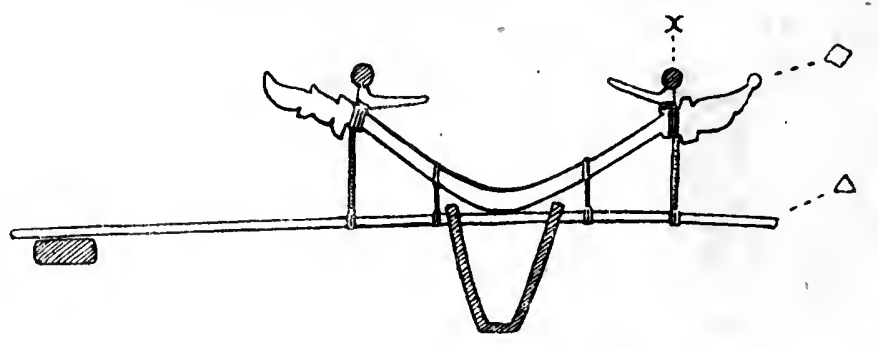

B
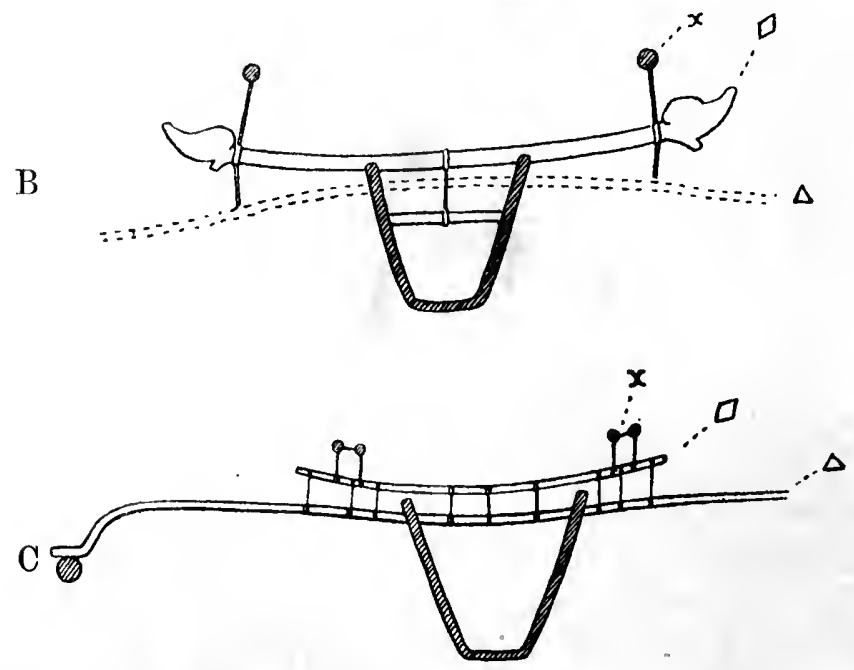

D)

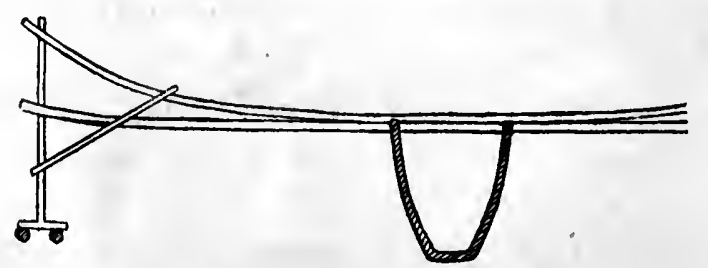

FiG. 2.-SECTIONS OF MODELS OF CANOES: A, SULU; B, MORO CANOE, ZAMBOANGa; C, MORO GANOE, ZEBU ; D, SANGIR (FROM MÜLLER, 1912, figs. 55, 56, 57, 58). 
(Wetter) Islands with a double outrigger of two straight booms, above which are equally long straight boom-spars, these evidently correspond with those just mentioned; but in this case there is a $U$-Moluccan attachment, the upper limbs of which are-lashed to its boom and boom-spar (Fig. 3). In a model canoe from Tenin ber in

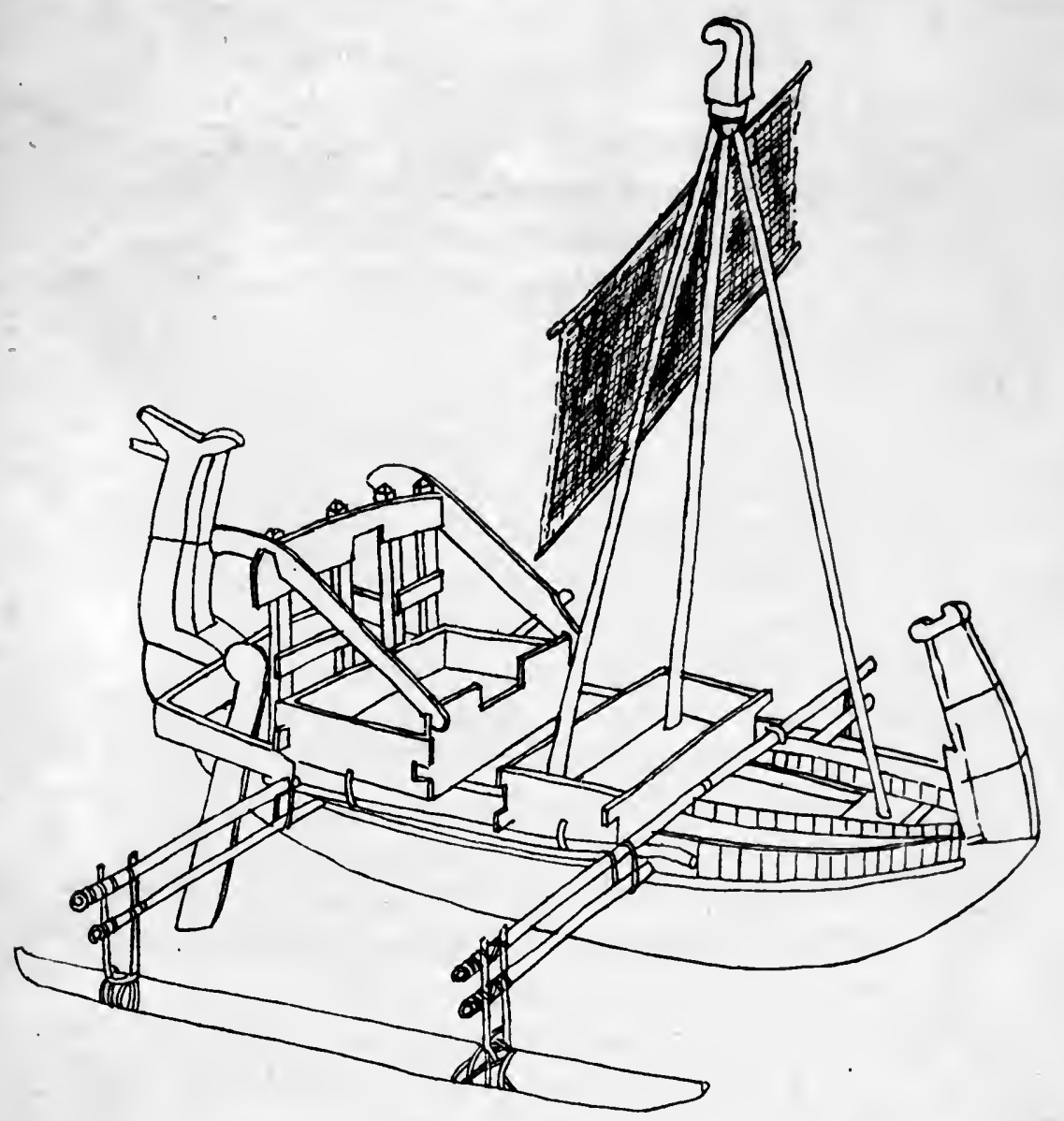

FIG. 3. - MODEL OF A SAILING SIIIP, WITI TRIPOD MAST, STRAI(IIT BOUMS AND bOOM SPARS AND A U-MOLUCCAN ATTACHMENT, WETTA (FHOM BAESSLER).

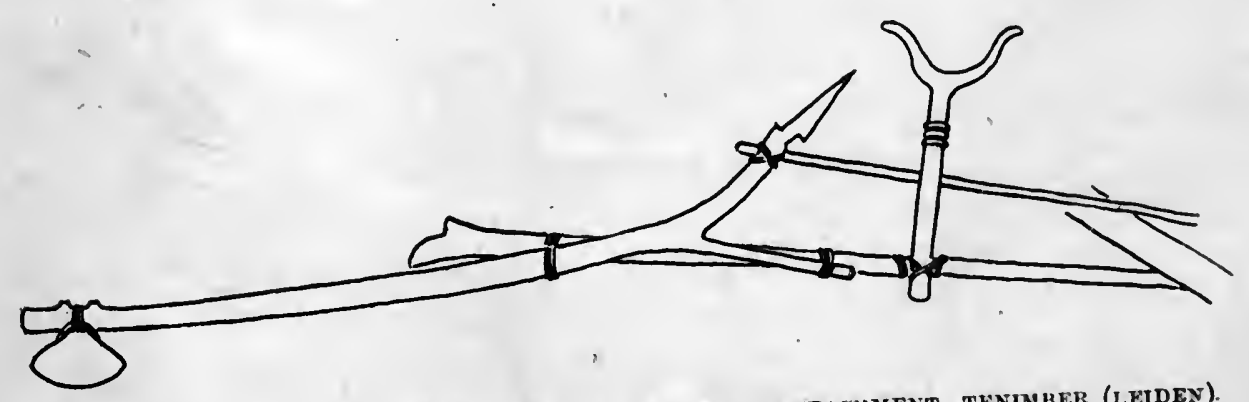

ETG. 4.- MODEL WTTH A BOOM SPAR AND haLMAHERAN ATTACHMENT, TENimber (LEIDEN). 
the Leiden Museum is a thin boom-spar above each true boom; it lies over a longitudinal spar which rests on the two booms and its end is lashed to the upper fork of a Halmaheran attachment (Fig. 4). Müller (1912, p. 244) describes a model of a canoe from Sangir in which the two outer (fore and aft) booms and their boom-spars are attached directly to the float, presumably by a lashing; the inner booms have the arrangement shown in Fig. 2, D, above each of these booms is an equally long and slender boom-spar which turns up at its ends; attached to the ends of the boom and boom-spar is the long stem of a $\perp$-shaped attachment-spar, beneath which the double float is fastened ; the boom-spar, boom, and attachment-spar are strengthened by a bracing spar; obviously all these elements are lashed together. At Kema, North Celebes (G., No. 232), the Sulu Islands (Guillemard, 1889, p. 192 ; G., Nos. 4, 115 ; Müller, Fig. 55; Savage Landor, II, pp. 2, 12), Zamboanga and Zebu in the Philippines (Müller, 1912, Figs. 56, 57), the upwardly curved boom-spar is greatly reduced in length and may become bowed and have carved ends. It does not support the float, but is attached by lashings to the unusually thin and fragile outriggerboom which is thus strengthened by the elasticity of the bowed boom-spar. As previously mentioned, the outrigger-booms, which usually are more than two in number, are attached directly lashed to the float. Müller (p. 245) describes the transformation of supernumerary boom-spars into curved crescentic ornaments in the Sangir and Sulu Islands; but these can no longer be termed boom-spars, as they are not necessarily connected with outrigger-booms.

Outlayers.-In describing the "Flying Praws" of Borneo, D. Beeckman says : "To prevent their oversetting, they fix two long Poles or Outlayers one across the Fore-part and another at the After-part of the Boat; each end being run into a large Bamboe . . . and when it blows hard, the People run out and in on the Outlayers, according as the Gale is fresher or abates, to keep the Boat upright" (1718, p. 91). Evidently this is what is referred to by R. Munday (1848, I, p. 52), quoting from [Raja] J. Brooke's Journal of January, 1840: "The small sailing boats [at Palette, Gulf of Boni, Celebes] had outriggers of wood, which weighted with men, enabled them to carry a sail of enormous size." Folkard says that the canoes at Manila have no outriggers, " but merely an outlager, or pole, laid across the vessel amidships, and extending several feet beyond the sides" (f.n., p. 482). Lane Fox (Pitt-Rivers) points out $(1875$, p. 430$)$ the practical utility of a single outlayer for canoes which have but a single outrigger ; he terms it a weather platform; when a flooring has been laid across the booms. He adds: "We have, in the Asiatic Archipelago, a contrivance which may be said to be derived partly from the double outrigger, and partly from the weather platform. . . . A weather platform had been found sufficient to balance the vessel on one side, and the next step was to knock off the outrigger $\log$ [float] on the other side, thereby converting the outrigger platform into a weather platform, the two platforms projecting one on each side of the vessel, on the level of the gunwales, without touching the water. . . . These double weather-platform boats 
were also found more eonvenient in inland waters, in the canals in Manila, and elsewhere." He also quotes the accounts of outlayers in the Philippines by De Guines (1796) and at Manila by Dampier (1686). "Balance poles" are referred to in the Census of the Philippine Islands, I, P. 326, Washington, 1905. The outlayer may very well be evolved from an outrigger, but as in the Philippines and Indonesia generally, the canoes have a double outrigger (when they have any at all), there does not seem to be any necessity for the intermediate stage of a single outrigger
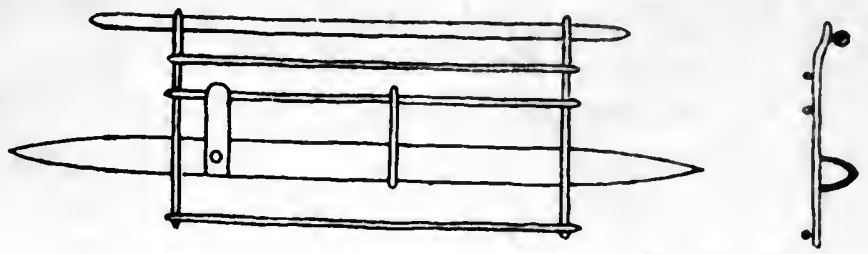

FIG. 5.-MODEL, OF CANOE WITH A DIRECT LASHED ATTACHMENT AND AN OUTIAYFR, SANOR, TALAUT ISLANDS (AMSTERDAM).

postulated by Pitt-Rivers for this area. In a carelessly-made model or sketch an outlayer might very well be mistaken for an outrigger. An outlayer may therefore be defined as a pole or a simple framework balancing apparatus, and may be single (Fig. 5) or double. When a platforn of boards or clnsely-laid bamboos or poles is formed, the outlayer may be termed a weather platform, which similarly may be single or double.

\section{Double Canoes.}

The only instance known to me of an Indonesian double canoe is that illustrated by Hickson (1889, Fig. 10, p. 164) : this is a small model used for ceremonial purposes in the Nanusa Islands to the north-east of Celebes beyond the Salibabu Islands. This sakit canoe is composed of two canoes close together; both have equally elongated upturned ends and are crossed by three booms, the ends of which are pegged on to the floats. Müller suggests that this idea of a double canoe may be due to Micronesian influence, and queries whether the outrigger may not universally be traceable to a double canoe (1912, p. 239).

Double canoes, janjar, are employed on the rivers of the Malabar coast, Southwest India, for conveying cattle and bulky goods across the rivers ; from the account by Edye these appear to be temporary arrangements (Edye, p. 6, Pl. III). In the Oxford Museum are three models of double canoes ; one is from "India," another from Mirzapore, on the Ganges, and the third from Ceylon. The importance of the double canoe in the early navigation of the Pacific is well known.

That double canoes once occurred in Indonesia is extremely probable, and we may assume that the double canoes of Oceania had their origin in Indonesia. 


\section{The Distribution of Single and Double Outriggers.}

Wherever outriggers occur in Indonesia they are double, with the exceptions noted below (see Map, p. 71) :-

Single outriggers alone are found in the Andamans (Fig. 11, A) and in the Nicobars (Fig. 10, B), but there are other canoes in these islands which are without an outrigger. The Sumatran sailing craft known as jellore has sometimes only one outrigger, which is then alternately to windward and leeward (Folkard, p. 481). H. von Rosenberg (1888, Pl. XVIII, Fig. 19) figures a model of a warship, knabat bogolu, from the Mentawei Islands (west of Sumatra) which appears to have but a single outrigger on the starboard side; it has two main booms which slope down.to the float and each has an accessory boom, which as it slopes down from the roof of the cabin, can hardly be termed a proper boom-spar; there is a double float and apparently a direct attachment (Fig. 1). Folkard states (p. 485) that on the north coast of Java, at Madura, they have sailing boats with single outriggers on the leeward side, while on a kind of rack on the windward side they sometimes place a canoe and everything on board that is movable. An aberrant type from the north coast of middle Java has been noted by Hornell. Pitt-Rivers (Lane Fox) mentions a single outrigger in Borneo, but does not give any reference $(1875$, p. 429) ; for toy canoes with a single outrigger from the Sarawak coast see Fig. 32. There is a model in the Amsterdam Museum of a canoe from Sangir with a single outrigger (Fig. 5), the two booms of which project on the other side of the hull to form an "outlayer": the downwardly curved ends of the booms are lashed to the float by a direct attachment. Numerous canoes with single outriggers from various parts of Indonesia are figured by Nicolas, De Bry and by Valentijn, but as the illustrations given by the old authors do not appear to be always accurate, this evidence cannot be fully relied on; as nearly all the boats are drawn in side-view, only one outrigger could be depicted. De Bry gives only one illustration of a double outrigger, a coracora ( $\mathrm{V}$, Pl. $c \mathrm{~A}$ ), which is also figured by Nicolas (II, Pl. 9), who calls it coracora or carcolle of Banda, but Nicolas figures (Pl. 14) a small war-vessel, carcolle, with one, and describes (p. 19) the carcolle of the King of Ternate as having a double outrigger. We are probably justified in assuming that the outrigger was double in all the Moluccan craft in which one was present.

To the west of Indonesia canoes with a single outrigger and two booms are found in Ceylon and parts of Southern India : as early as 1599 Lintscotus figured the type occurring at Goa and Cochin (II, Tab. XIV). They also extended to the Maldives.

Canoes with double outriggers and two booms occur on the coast of Eastern Africa, the Comoro Islands, and North-western Madagascar. In Madagascar the larger canoes appear to have but one float, though the booms project beyond the other side of the hull to form an outlayer (Haddon, 1918, No. 29). I regret that in this paper I omitted the record by Müller in Madagascar of small, double-outrigger coasting 
canves, and of a large Sakalava sailing boat, lakka fiara, with a single outrigger, the float of which has superfluous, overloaded terminal enlargements that resemble the ends of the Hawaiian double canoe, and, Müller adds, perhaps is evidence that Malays voyaged to Madagascar in double canoes $(1912, f . n .$, p. 239). I have recently come across a book by L. (1598) who gives a plate, on p. 6 (drawn in 1595), of two dugouts with a double outrigger of two booms and a vertical stick attachment; the float appears to be a long thin log. This is the earliest record known to me of this kind of craft in Madagascar, and it adds to the interest to find that it occurred in St. Augustin Bay on the south-west part of the island.

To the east of Indonesia canoes with a single outrigger are the common type in Oceania, and in New Guinea they begin to appear in Geelvink Bay and continue down the coast (p. 122, and Haddon, 1913). The double outrigger is found throughout Geelvink Bay and ceases at Cape D'Urville, at its eastern entrance, but within this area the single outrigger predominates and, like the double-outrigger type, has three or four to a dozen booins. Both kinds of canoes have a new type of attachment which consists of a nail-like wooden spike or stick which passes from above through the end of the boom and is driven vertically into the float. Spikes are usually selected which have a natural thin branch projecting at right angles; this is laid over the boom and tied firmly to it (Fr., II, pp. 249, 252-254). Both kinds of spikes (i.e., with or without the branch) appear to be used indiscriminately and separately, at all events at Ansus (Guillemard, pp. 401, 402, 404; G., Nos. 271, 296, 302, 439, 442). This may be termed a "spike attachment." An inner longitudinal spar is frequently present (p. 127).

\section{The Number of the Outrigger Booms.}

South of a line which passes north of Borneo, Celebes, Halmahera, and Ceram the outriggers almost invariably have but two booms, whereas to the north and east of it they have usually four, rarely more, sometimes three and occasionally only two booms (Map, p. 7.).

In the Andamans the smaller canoes are fitted with a single outrigger consisting of three to seven booms (A. R. Brown MS.). Mouat figures four (p. 315), as does Folkard (p. 460). Man (XII, Pl. VII) gives a photograph of a small " dug-out called châ-rigma" (p. 116), which has three. Models in the British, Cambridge, Edinburgh, Halifax, Horniman, and Oxford Museums have three. As the early writers did not inention an outrigger, Mouat thought that it was a recent introduction, but Man (XI, p. 272) denies this. Mouat also supposed that it was adopted from the Ceylonese craft, but the type of attachment entirely negatives this wild suggestion. As we shall see, the stick attachment is, however, very close to that of the Nicobarese canoes.

There are only two booms in the Nicobarese canoes.

Jurging from photographs (G., No. 267) four booms may occur at Misol and Weda 
Bay (G., No. 292, Fig. 6), but usually in Weda Bay, Patani, and Bali, all in Halmahera, the outrigger has two booms with a Halmaheran attachment, but frequently there is a central "false boom," the end of which is connected only by a lashing to the centre

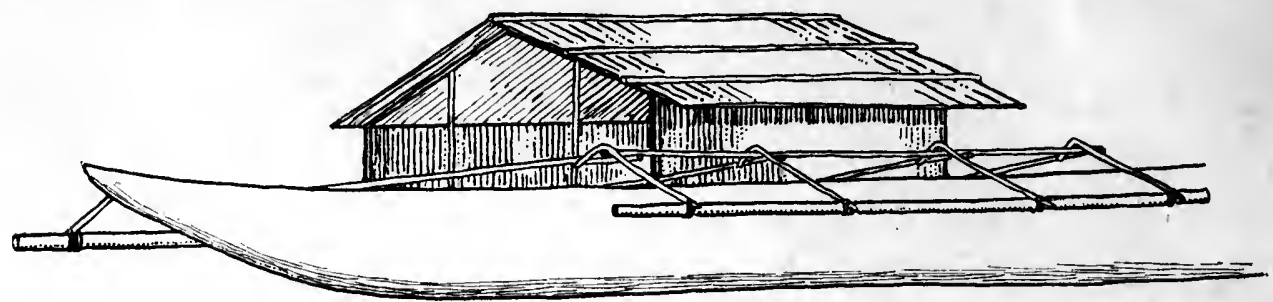

Fig. 6. CANOE WITH DOUBle OUTRIGger, FOUR BOOMS, AND HALMAHERAN ATTACHMENT, Weda bay, halmahera (Photo G., No. 292).

of the float (Friederici, II, p. 242). Forrest figures a "Molucca Corocoro" (pl. 4, p. 82) with three booms off Batjan ( $f f$. p. 110), and a similar vessel at the Kanari Islands, north-west of Misol (pl. 15, p. 172).

There is a model of a large plank boat from Gowa, South Celebes, in the Leiden Museum, with a double outrigger, five booms with a direct attachment to each float ; of these the fore and aft booms are inserted into the float, while the three middle ones are lashed to the underside of the float. It would not be surprising if this were a model of a craft coming from the Sulu area (p. 114). There are usually three booms. at Buton, an island off the south-east point of Celebes (Friederici, II, p. 235). Professor S. J. Hickson has presented to the Cambridge Museum several small models of ceremonial sakit canoes from Nanusa Island, north-east of Celebes; they have either two or three booms which are pegged ${ }^{1}$ on to the floats, or the outrigger may be absent (1893, Fig., p. 290). This island is just on the above-mentioned border line. In spite of these exceptions the canoes of Celebes appear predominantly to have but. two booms.

More than two booms usually occur in the Sangir Islands (Müller, p. 244).

In the Sulu Islands small canoes may have but two booms (Guillemard, 1889, p. 206 ; G., Nos. 180, 217), but usually there are three (Fig. 7) (Wilkes, V, p. 333 ; Burbidge, p. 225 ; G., No. 4) or four (Guillemard, 1889, p. 192 ; G., Nos. 115, 142,

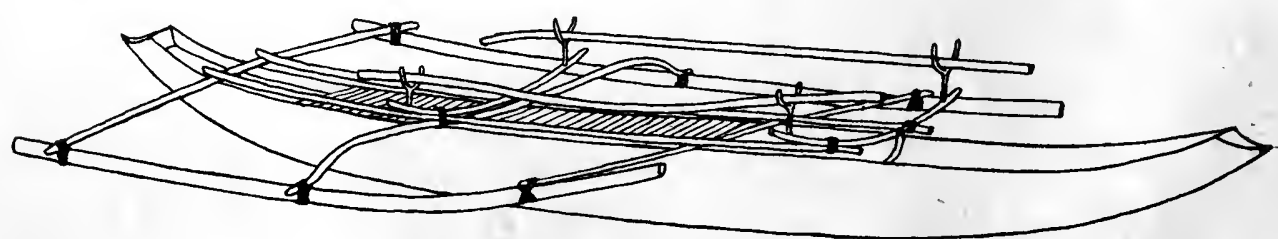

FIG. 7.-CANOE WITH DOUBLE OUTRIGGER, THREE BOOMS, AND DIRECT LASHHD ATTACHMEN'; SULU (Photo G., No. 4).

1 I do not regard the pegs as being significant ; they are probably merely a labour-saving device. 
180, 192, 211 ; model of a "piratical prahu," dapang, Edinburgh Museum). In these canoes the fore and aft booms are always straight, whereas the central booms are downwardly curved at their ends (Fig. 7). Pritchett (p. 183) illustrates a "Pirate craft off north point of Borneo" with a double outrigger consisting of three downwardly curved booms (Fig. 8); it was probably a Sulu vessel.

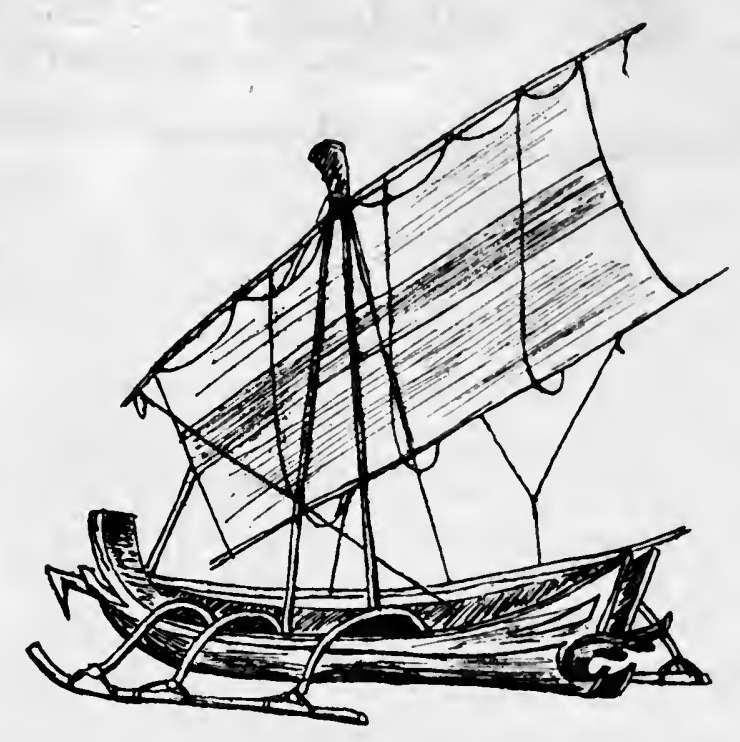

FIG. 8. - PIRATE CRAFT OFF NORTH POINT OF BORNEO (AFTER PRITCHETT, p. 183).

In the Philippines three booms may occur at Manila and on Lake Lanao in Mindanao (Vojnich, pp. 378, 383).

In numerous pictures of the East Indian seas given by old Dutch voyagers there are depicted large sailing war-vessels with massive outriggers possessing several (usually three) booms, on or under which are fastened a variable number of longitudinal planks (i.e., parallel to the hull) which are used as seats by the paddlers. I shall refer later to these craft and to the ancient Indo-Javanese vessels which had at least three booms to their outriggers. Weule figures (Pl. 112, Fig. 7) a double outrigger "Boot von den Molukken," but gives no further particulars; it has three booms and what may be a Moluccan attachment, a board is lashed to the underside of the booms midway between the hull and each float, on which three men sit and paddle.

Throughout Polynesia, with but few exceptions, the canoes have two outriggerbooms. Two straight booms are found in the Pelew, Marianne, and typically in the Caroline Groups ; characteristic of the Marshall Group are two straight booms, the end of each of which is supported by a straight stick which is inserted into the float and apparently also into the boom, on each side of the booms are three curved 
booms, the ends of which are lashed to the float (Model, Salem Museum ; Alexander, pl. 36, pp. 805, 806), a variant from Nonuti, Gilbert Islands, is shown in Fig. 29 see also p. 124. Equally characteristic is the presence of three (or four) out-riggerbooms in Melanesia, but in New Guinea there is considerable diversity. In all of these areas there is a single outrigger, with the exceptions noted on pp. 79, 122 ; in those cases where the outrigger is double there are but two booms.

The only instances known to me in Indonesia of but one outrigger-boom are those associated with a single outrigger in a toy boat from Borneo (Fig. 32), and in the case recorded by Hornell from North Java (1919, Fig. 1), and the model from Manila (p. 114, Figs. 30, 31) in which the outrigger is double.

Professor J. Stanley Gardiner has given to the Cambridge Museum a toy canoe, $a b b u o d i$, from the Maldive Islands. It has a single outrigger and only one boom, the end of which is morticed into the float. He informs me that boys frequently use canoes with one, two, or three booms. The men's canoes have no outrigger, but the old people say that outrigger canoes were formerly used extensively; one man called them " rafts."

There is a model in the Peabody Museum, Salem, Mass., of a canoe from Ruk, Caroline Group, with a long single boom on one side only which is strengthened by two horizontal convergent sticks from the fore and aft quarters of the hull; there are two central parallel short ridges on the canoe-shaped float, the boom rests in a notch in the inner one and is inserted into a hole in the outer one. Müller (1917, I, Fig. 295 , p. 199) gives an illustration of a toy sailing canoe, tatărĕg, from Yap in the same group ; it is something similar to the preceding one, but there is an obscure indirect attachment. The play-boat figured by Krämer (1906, p. 291) from the Gilbert Islands appears to be very similar.

\section{The Attachment of the Booms to the Hull.}

In the majority of cases the booms rest on the gunwales, especially when the hull consists solely of a dug-out. In the Andamans, however, the booms pass through holes in both sides of the dug-out (Fig. 11, A, D).

It not infrequently happens that a length of sapling or bamboo is lasbed to the upper border of the dug-out and the booms rest on this gunwale spar, as it may be termed. The object of this spar is obviously to protect the edges of the hull; it is widely distributed in Oceania.

In the Nicobars, according to A. R. Brown MS., the booms rest on the gunwales and a gunwale spar is fastened over them along the length of the canoe (Fig. 10, B), but Svoboda (VI, Pl. 1) figures the ordinary arrangement.

Sometimes the booms lodge in notches in the gunwale, or the gunwale may be locally raised at the spots which support the booms; the upper edges of these protuberances may be notched. 


\section{The Float.}

The float usually consists of a single log of wood or piece of bamboo. When not otherwise stated it may be assumed that the float is single, but occasionally two or more bamboos (or pieces of wood) are employed, in which case it may be termed a double, treble, or multiple float.

The float, when made of bamboo, has its ends cut square, but when made of wood it is usually trimmed; the fore end only or both ends may be pointed, or the fore end and occasionally both ends may have an upward curve.

\section{The Attachments between the Booms and the Float and their Distribution. ${ }^{1}$}

There are various methods in the attachment between the booms and the float. The main groups are :-

\section{A.-Direct.}

1. Inserted.-The ends of both booms are inserted into the float. This appears to be very rare, if it actually does occur in practice, in Indonesia. According to Folkard's drawing (p. 480) the Sumatran jellore and ballellang have booms with downwardly curved ends which appear to be inserted into the floats; unfortunately the drawings in his book are on too small a scale for the details of attachment to be reliable. The toy boats of Sarawak (Fig. 32) have this method. The Balinese attachment (p. 88) really belongs here.

2. Lashed.-The ends of all the booms are lashed to the float (Figs. 1, 2, 5, 7). This type is widely spread throughout Indonesia. It has been noted at Mentawei (Rosenberg, Pl. XVIII, Fig. 9) ; Engano (model, Leiden); Palembang in Sumatra model, Amsterdam); Madura (model, Amsterdam ; model, Leiden, in this case each float consists of two bamboos between which is a small peg which projects on the under and upper surfaces of the boom, evidently to render the lashing more secure); Java (L., I, p. 35b) ; Bali (Fr., II, p. 235, Fig. 1, on a dyukun canoe); Sumba or Sandalwood Island (model, Amsterdam); Lomblen, between Flores and Timor (model, Leiden); Baba, west of Tenimber (Pflüger, p. 145, no description ); freshwater creek of Totoat, Kei Islands (Langen, p. 52, poor figure, no description); Lintschotus illustrates a sailing vessel apparently of this type with the inscription "Navium quibus Bantani utunter" (Tertia pars, DCI, XXIIX $h$ ), but the booms may have been inserted into the float; Lake Wakollo or Wakoholo, Buru (Forbes, Pl. p. 405, no description; K. Martin, 1894, p. 329, Pl. XLV, with three slightly curved booms) ; Batjan (G., No. 336) ; Ternate (L., II, Pls. 14, 15 ; Kükenthal, Pl. 7, Fig. 13, obscure, no description); Lake Galela in North Halmahera (Kükenthal, p. 172); Makassar (Valentijn, No. 23, p. 136); Gowa in South Celebes (model Leiden); Paloppo and Libukang in the Gulf of Boni, Celebes (P. and F. Sarasin,

1 Map, p. 71. The distribution outside of Indonesia is given later, p. 124. 
1905, I, Fig. 53 ; II, Figs. 62, 63) ; Ussu on the Malili River and Lake Matanna, at the north-east end of the Gulf of Boni and Paloppo (Grubauer, Figs. 15, 38, 39, 108); Kema, North Celebes (G., No. 62) ; Sangir (model, Amsterdam, single outrigger with two booms and an outlayer, Fig. 5) ; Talaut Islands ("Geisterkahn" or sakit canoe, Dresden, Meyer and Richter, Pl. I, Fig. 10) ; Sulu Islands (Wilkes, Vol. V., p. 333 ; Burbidge, p. 225 ; Savage Landor, II, pp. 2, 12 ; Müller, p. 244, Fig. 55 ; Guillemard, 1889, pp. 192, 206 ; G., Nos. 4, 142, 180, 211, 217) ; Cagayanes Group (Savage Landor, I, p. 228) ; Manila and district of Lake Lanao, Mindanao (Vojnich, pp. 378, 383) ; Pasig River, Manila (p. 114, Fig. 30) ; Zamboanga and Zebu (Müller, p. 244, Fig. 57); the "Pirate craft off north point of Borneo" (Fig. 8) (Pritchett, p. 183) appears to belong here.

In a large canoe at Amboina figured by Valentijn (No. XXX, p. 124) the booms seem to be lashed directly to the float, they have a zigzag appearance and support planks for paddlers, but the illustration is not convincing.

3. Mixed Direct Attachment.-A model of a fishing boat, sampan, from Panarukan, Madura Strait, in the Rotterdam Museum, has two booms, one of which is straight and tied to the float, while the other is downwardly curved and inserted into the float. Practically the same arrangement is shown in a model from "Java" in the Amsterdam Museum (Fig. 9). In the Leiden Museum are two models from Madura, in which the fore boom is straight with its ends lashed to the floats, while the aft boom is short and straight and has inserted into each end a straight spar with a downwardly

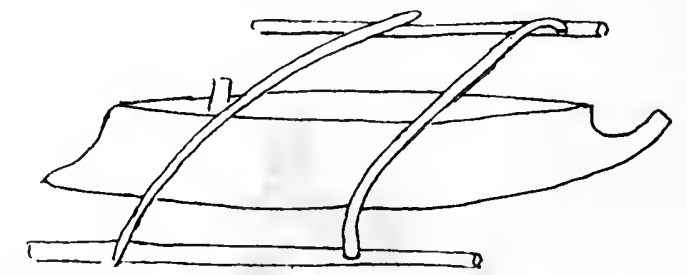

FIG. 9.-MODEL WITH DOUBLE OUTRIGGER AND MIXED DIRECT ATTACHMENT, JAVA (AMSTERDAM).

curved end which is inserted into the float; these booms are probably intended to represent a sedek (p. 89), and if so this is an example of a mixed direct and Balinese attachment. I think in all these cases it is the fore boom which is lashed to and the aft boom which is inserted into the float.

A model of a large plank boat in the Leiden Museum from Gowa, South Celebes, has five booms of which the fore and aft booms are inserted into the float, while the three middle ones are lashed to the underside of the float (pp. 80, 106, 113, 114).

\section{B.-Indirect.}

(a) Attachment inserted into the Float.

Stick Attachment.-Attachments which consist of one, two, or more sticks, one end of each stick is lashed to the boom while the other is inserted into the float. 
The sticks may be vertical, in which case there may be only a single stick, or there may be two or more sticks, either on one or on both sides of the boom; the sticks may be irregularly oblique, in oblique parallel pairs or a pair of oblique sticks may converge over the boom; a pair of sticks may cross under the boom, undercrossed, in which case the boom typically rests on the crossing, or the crossing may take place over the boom, overcrossed.

In the outrigger canoe, $d u \bar{e}_{s}$ of the Nicobars the attachment consists typically of a double set of three sticks, heneme, which are inserted into the float, hentaha, and lashed to the boom, deia due, in such a way that two sticks generally cross each other below the boom, while the third may be vertical or oblique, and may be fore or aft of the boom (Fig. 10, C, D); occasionally a pair of sticks converge over the boom, the third being more oblique (Fig. 10, F).' The two sets of three sticks diverge from the median line of the float (Fig. 10, A). Sometimes there is also a central pair of undercrossed sticks, which is inserted vertically between these two, as in
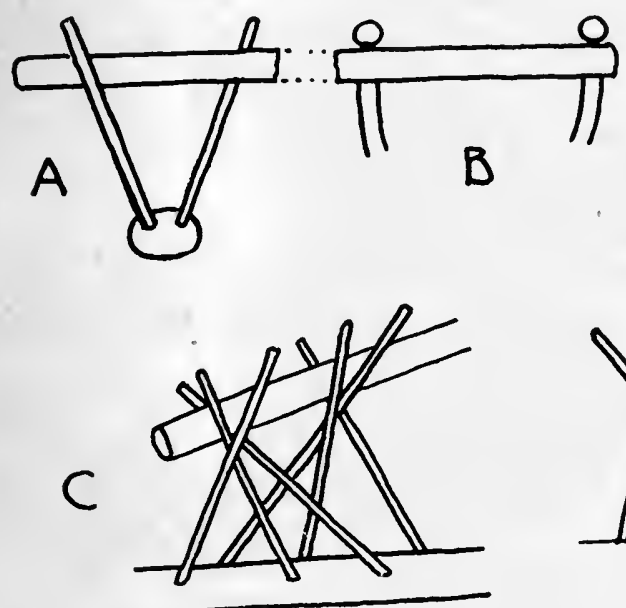

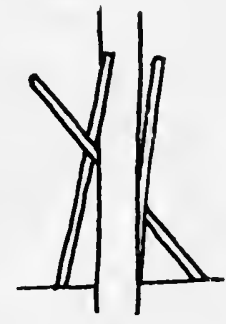

F
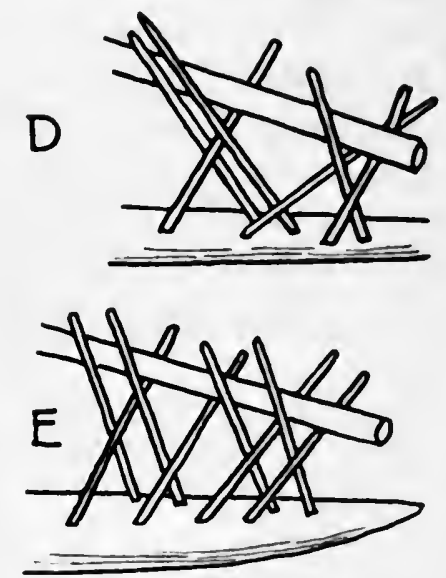

FIG. 10.-STICK ATTACHMENTS, NICOBARS : A-C (A. R. BROWN MS.) C, REPRESENTS THE ARRANGEMENT OF THE STICKS ; IN A, ONLY TWO OF THE SIX STICKS ARE SHOWN ; D, E, MODELS (OXFORD); F, MODEL (EDINBURGH).

models in the Oxford Museum (Fig. 10, E). In a model in the Edinburgh Museum one set consists of two sticks which are almost parallel and converge slightly over the boom and a third oblique stick (Fig. 10, F).

The native names are taken from Svoboda, who does not describe the arrange. ment of the sticks, nor are his figures at all clear (VI, Pl. I, Figs. 11, 17); he also gives an illustration (V, p. 193) of a toy canoe in which both booms pass through the hull and rest on the float and are tied to an adjacent short peg which is inserted into the float. A good illustration of a model of a sailing canoe, which shows the details of the sticks, is given by Man (XI., Pl. XXIV), later (XV, pp. 436, 449) he alludes to Nicobarese canoes without saying anything about outriggers. Kloss (pp. $53,79)$ gives short accounts of the canoes, $a p$, and two excellent plates (pp. 80, 154); 
the latter shows the attachments very well, as does the plate, p. 345, Journ. Anthrop. Inst., VI, 1877, cf. p. 209.

The Andamanese attachment consists most frequently of one set of two undercrossed sticks and one vertical stick, which may be on either side of the boom (Fig. 11, B). This arrangement occurs in one attachment in a model in the Cambridge Museum, while in the other two attachments two sticks cross over the boom and a third vertical stick is present (Fig. 11, D). In a model in the Horniman Museum the three booms each have an attachment of only two sticks which converge over the boom. Models in the British Museum, Oxford, and Edinburgh Museums, have three booms with a single pair of oblique sticks which cross under the boom (Fig. 11, E).

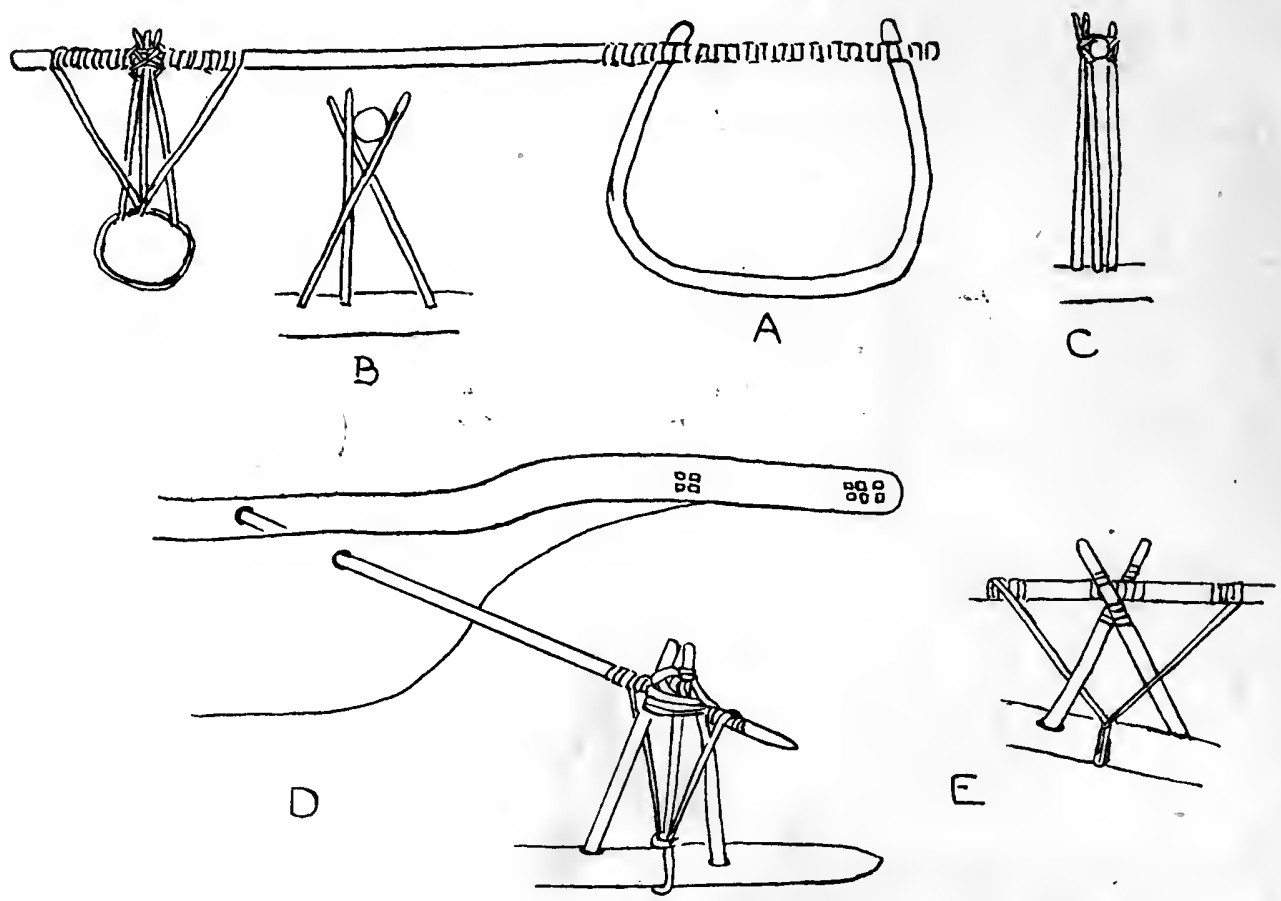

FiG. 11.-STICK atTACHMENTS, ANDAMANS : A, B, GREAT ANDAMAN, C, LITTLE ANDAMaN (A. R. BROWN MS.); D, MODEL (CAMBRIDGE); E, MODEL (BRITISH MUSEUM).

In the Little Andaman (A. R. Brown MS.) there are three vertical sticks, two on one side of the boom and one on the other. There is, however, some variation in the arrangement in the various models, even in the attachments of the several booms in the same model ; for example, in the Halifax Museum, a model of a large canoe, roko, has three booms-the attachment of two is typical, while in the third the boom passes between a pair of crossed sticks and the vertical stick, but this is probably due to careless workmanship. There is frequently in addition a couple of lashings (Fig. 11, A, D, E) or a single one, of ratan from the boom to the float to render the attachment more secure. A good photograph of an outrigger canoe, châ-rigma, and of the larger kind without outriggers, gi lyanga, is given by Man (XII, p. 116, Pl. VII). 
With these exceptions, a stick attachment of this kind has not been recorded for Indonesia, though, as we shall see (p. 125), it is very common in Oceania.

Rod Attachment.-This attachment, which consists of a more or less vertical rod or stick inserted into the float at its lower end, has not hitherto been recorded from Indonesia as an attachment for all of the booms of a canoe. That it may have occurred there is possible, as it is found in some mixed types (pp. 92, 96). To avoid confusion with the above-mentioned stick attachment this may conveniently be termed a "rod attachment."

Spike Attachment (pp. 79, 127). Y-shaped Stick Attachment (p. 127).

Board Attachment.- Hornell has recently described a form of attachment to which the term "board" may be applied (1919, No. 55). It consists of a short, broad and relatively thin piece of wood; its lower end is inserted into the float while the boom passes through its upper end ; in these two respects it resembles the more stick-like attachment of the East African canoes (pp. 79, 128; Haddon, 1918, No. 29). This attachment has been recorded only from the north coast of Middle Java, where it is associated with a single outrigger and a single boom. It seems to be related, however, to an attachment figured by Nicolas (1601, II, Pls. 14, 15, 17) on trading- and war-vessels at Ternate (p. 110) and by De Bry (1601, V, Pls. XII, XVI) on similar craft from the Moluceas. At that time the larger boats of the Moluccas had a double outrigger of three stout straight booms, each of which was supported in a deep notch in a short board which was apparently inserted into the float (Fig. 12 B). I propose to refer to this type as a $Y$-board attachment. Valentijn

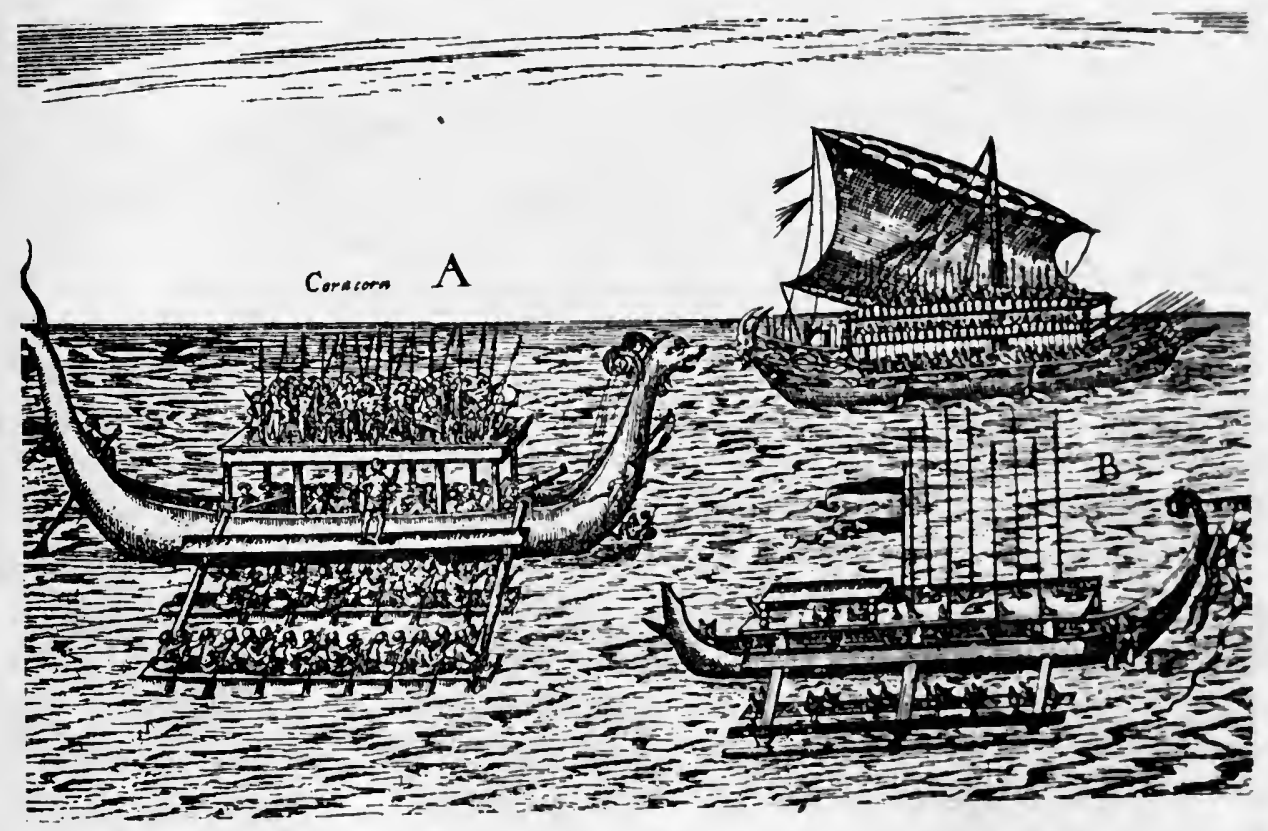

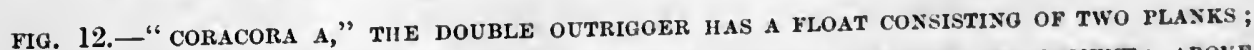

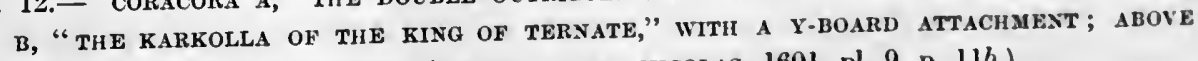
THIS IS A MAdURA WAR SHIP. (DE BRY; AND NicOlas, 1601, pl. 9, p. 11b.) 
(p. 363) shows these boards as also lashed to the floats on Moluccan vessels. A thick longitudinal spar or board ran across the ends of the booms, presumably to keep them in place, this was frequently utilized as a seat for paddlers. In one coracora there was apparently a straight Halmaheran attachment near each end of the longitudinal spar. Generally one or two planks are fastened transversely to the booms upon which men sit to paddle. In an illustration entitled "De Cora-cora van Titaway" (Fig. 13) there are six outrigger booms which are supported by as

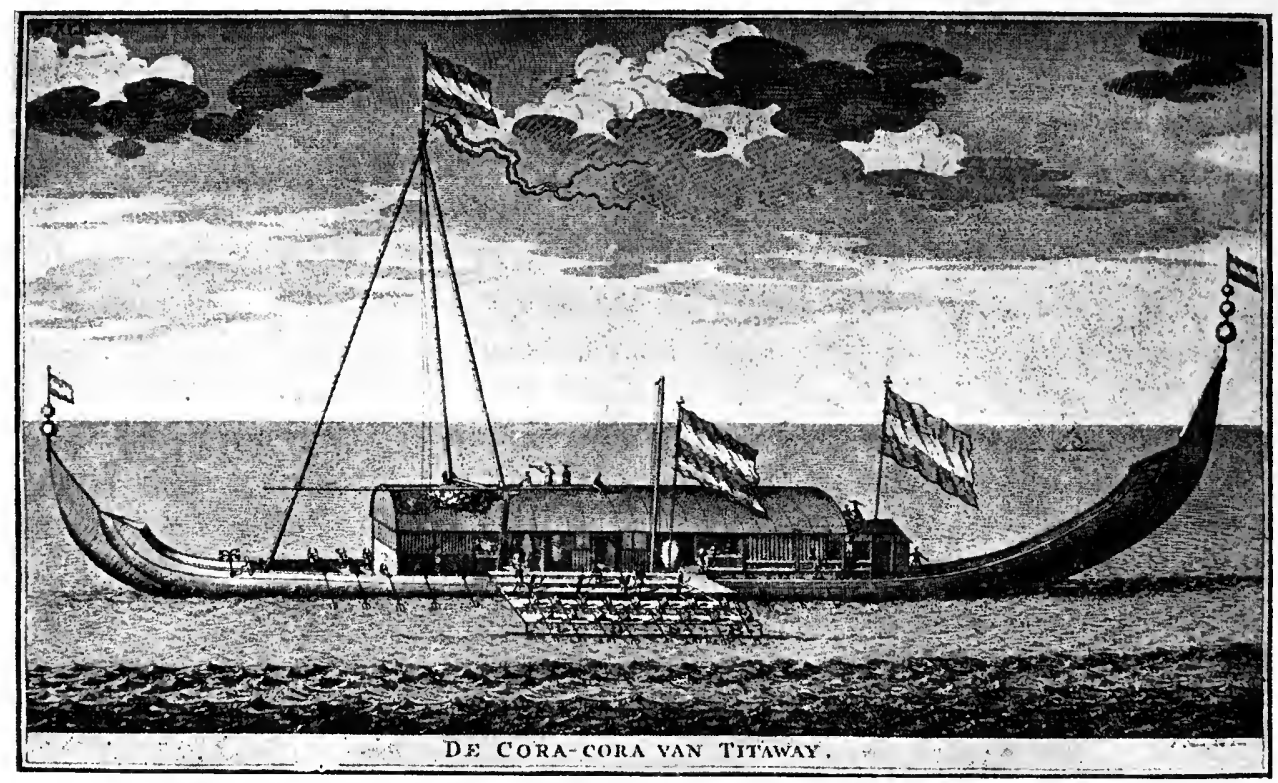

Fig. 13.- "de cora-Cora van titaway" (VAlentiJn, No. xli, p. 184).

many short, thick, squared bars of wood which appear to be inserted into the float, a plank on which eight men sit to paddle replaces the longitudinal spar, there are four other similar planks on the lowermost of which are also paddlers.

Balinese Attachment.-We may adopt Hornell's term for the type of attachment which consists of a straight or slightly curved spar one end of which is spliced, pegged and lashed to each end of both of the short straight booms, the other being inserted into the float and reinforced by lashing (1919, No. 55). This type was first described and figured by Friederici (II, p. 235, Fig. 2) (Fig. 14 A), who gives the Bali names for

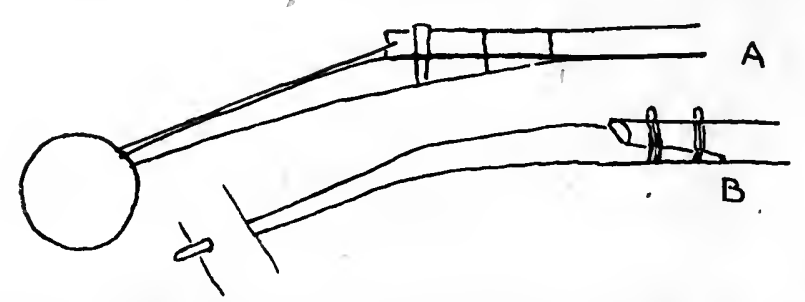

FiG. 14.-BALINese ATtaChMent : A, BALI (FRIEDERICI, II, fig. 2); B, Model From BaNJUWANGJ, E. JaVA (EDINBURGH). 
boom, brayunan, "intermediate piece," sedek, and float, kater. Hornell gives a good photograph (1919, Pl. G., A) of a Lombok canoe, and figures details of the sedek from Boleleng, Bali. There is a model of a sailing boat, dukong, from Banjuwangi, Java, on the Bali Strait, in the Edinburgh Museum with this attachment (Fig. 14 B).

Hornell suggests that this is a device for extending the boom downwards so as to save the necessity for searching for a naturally-bent piece of wood with which to construct an outrigger-boom of the required form. As I have stated (p. 73), the sedek may be regarded as one form of the "boom-prolongation." If the sedek were a form of Halmaheran attachment one would expect it to be only lashed to the float, whereas it is inserted into it, as it appropriately would be if it were derived from a direct inserted attachment; the upper end is virtually an integral part of the boom and not a spar lashed on to it. As the sedek is an added piece, this form of attachment is strictly speaking "indirect," but if it be regarded merely as a prolongation of the boom it should be described as a " direct inserted attachment."

\section{(b) Attachment tied to the Float.}

Moluccan.-The typical Moluccan attachment is formed by a $U$-shaped piece of ratan, the horns of which are lashed to one side of the free end of each of the booms, and the base is lashed to the float (Figs. 3, 15).

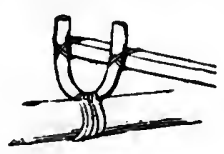

A

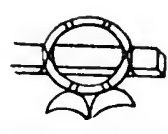

$\mathbf{B}$

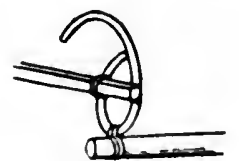

$\mathbf{C}$

FiG. 15.-MOLUCCAN ATTACHMENTS: A, BATJAN; B, AMBoINA; C, BANDA (A, C, FRoM PHOTOGRAPHS, G., 334, 161 ; B, AFTER FRIEDERICI, Il, fig. $7 a$ ).

It has been noted from models at Wetta (Riedel, Pls. XLI, Fig. 12 ; XLIII, Fig. 8, Baessler, p. 78, Pl. VII, Fig. 4) ; Batu mera in the south-east islands of the Kei Group (model, Amsterdam) ; Buru (Riedel, from model, Pl. I ; Fr., "here and there," III, p. 161); Amboina (K. Martin, 1894, p. 232 ; Fr., II, Fig. Ta, p. 237 ; model, Leiden, on aft side of all the booms); Uliassers (Fr., III, p. 161); Ceram (Fr., III, p. 161, " with the exception of a few places on the north coast"; South Ceram, K. Martin, 1894, p. 232, Pls. XII, XXVIII, Fig. 15) ; Ombi, north of Ceram (Fr., II, p. 239) ; Batjan (Fr., II, p. 239, "predominates" ; G., Nos. 328, 331, 334, 336); Ternate (Kükenthal, Pl. 5, Fig. 8; Fr., II, Fig. 11, p. 240, "greatlylpredominates"; G., No. 327) ; northern Halmahera ("occasionally" at Ake-Selaka, Tobelo and Galela, Fr., II, pp. 240, 242, Figs. 11, $27 a$; III, p. 161) ; Buton (Fr., II, Fig. 3, usually with three booms and three bamboos to form the float, p. 235).

Other varieties of this type are the $O$-shaped attachment which predominates at Amboina (Fr., II, p. 237 ; Pflüger, p. 131 ; models, Leiden), and the 6-shaped attachment which is the common form at Banda (Fr., II, p. 237 ; G., No. 161). 
The Moluccan attachments of boats between Selang and Batjan figured by Forrest (pl. 4, p. 82, pl. 5, p. 86) are not very clear; the former is a "Molucca Corocoro," and has three booms, a tripod mast and a lyre tanjong sail.

Halmaheran.-This attachment consists of a variously shaped spar which is lashed above to a boom and below to the float (Figs. 4, 6, 16, 17).

In order to prevent confusion with the "stick" attachment, which is inserted into the float, I propose to refer to this element as a "spar," even when it is a simple rod or stick. This is the "oblique" or "elbow-stanchion type" of Hornell. The term "Halmaheira-Verbindung," like that of "Molukken-Verbindung," was introduced by Friederici (II, p. 239).

The simplest condition consists of a straight spar which may be vertical, as in a Batjan canoe (Fig. 16 F; G., 336) and in a sailing vessel, bero, at the Tenimber Islands (Riedel, Pl. XXVII, Fig. 9, I assume that the spar is tied to and not inserted into

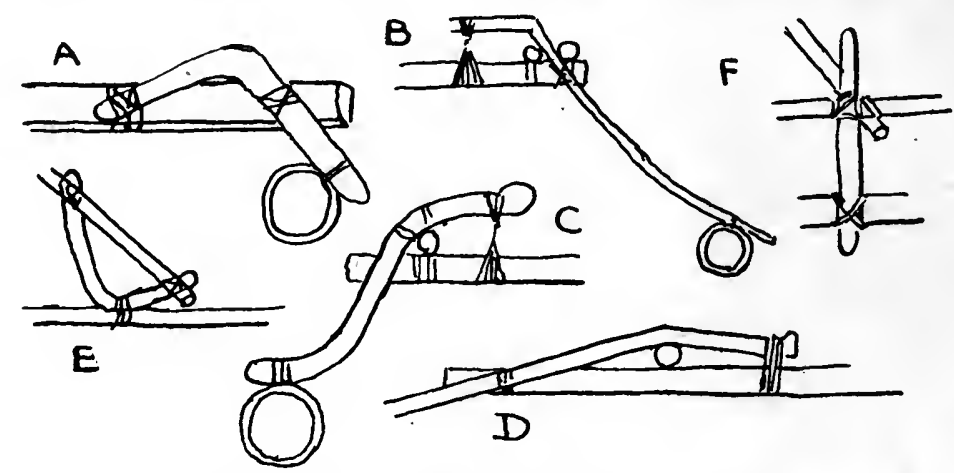

Fig. 16.-HALMAHERAN ATtAChMENTS: A, BUTON ; B, C, AKKE SELAKa, AND D, WEDA BaY, HALMAHERA (FRIEDERICI II, pp. 235 ff., figs. 4, 22, 17, 27); E, MODEL FROM TALAUT (AMSTERDAM) ; F, BATCHAN (РНOTO G., 336).

the float in this case); or oblique, as in a canoe on the Bay of Bara, north coast of Buru (K. Martin, 1903, Pl. XIV) and Banda (G., 346). The attachment of the central booms of the Sangir canoe (Fig. 2, D) may be a variant.

The spar may be forked and practically horizontal (model from Tenimber, Leiden), p. 76 and Fig. 4 ; usually it is more or less vertical, Batjan (G., Nos. 328, 331), Misol (G., No. 267) or oblique, North Ceram (K. Martin, 1894, Pl. XXVIII, Fig. 16).

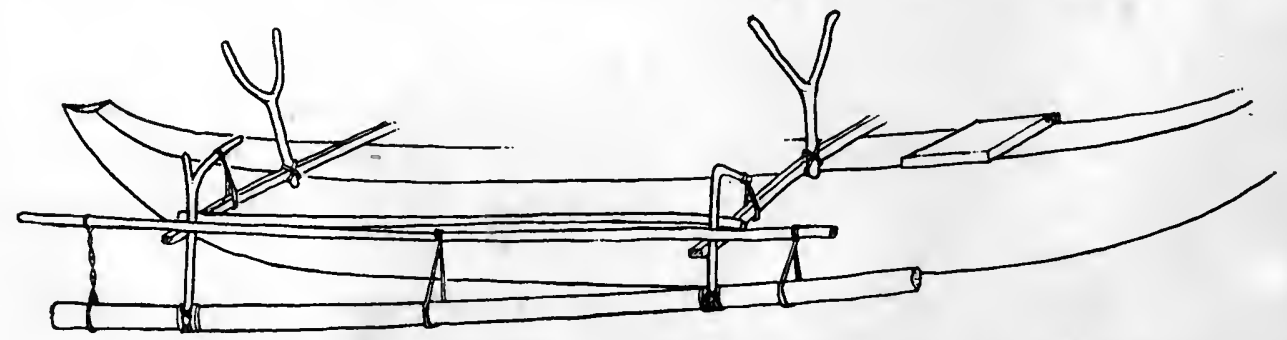

FIG. 17.-CANOE WITH DOUBLE OUTRIGGER, HALMAHERAN ATTACHMENT, AND AN INNER AND AN OUTER LONGITUDINAL SPAR, BATJAN (FROM PHOTO ส., 331). 
Most frequently the spars are angled, elbowed, or bent in various ways (Fig. 16). If the main stem of a forked spar were cut off immediately above the fork an angled spar would result. The stem may be straight and the upper part bowed (Fig. 6) ; the spar may have a slight sigmoid flexure, which may be so slight as to be almost straight. Occasionally the spar is sharply bent, with the ends pointing downwards, as in a Buton canoe (Fr., II, p. 235, Fig. 4), or with the ends pointing upwards as in a model from Talaut in the Amsterdam Museum (Figs. $16 \mathrm{~A}$ and $\mathrm{E}$ ).

These variations, so far as my data go, do not appear to be significant as regards form or distribution, since nearly every variety occurs on the coasts of or on the islands immediately adjacent to Celebes, and elsewhere several varieties are found in the same spot; sometimes two varieties may be found on a single canoe.

It occurs at Lombok ("common," Hornell, p. 99) ; Timor (photo.) ; ? Baba (Pflüger, p. 147) ; Tenimber (Riedel, model, Pl. XXVII, Fig. 9 ; model, Leiden) ; Dobbo, Aru Islands (0. Warburg photo. in Krieger, Pl. 29) ; Buru (K. Martin, 1894, Pl. XLVI, 1903, Pl. XIV ; Hornell, p. 99) ; Banda and Ambon ("occasionally," Fr., II, p. 239) ; Ceram, north coast (K. Martin, 1894, p. 232, Pl. XXVIII, Fig. 16 ; Fr., II, p. 239 ; Hornell, p. 99) ; Misol (G., No. 267) ; Ombi (Obi) (Fr., II, p. 239, "common type" ; Hornell, p. 99) ; Batjan (" a few," Fr., p. 239 ; G., Nos. 328, 331, 336) ; Tidor (K. Martin, 1894, p. 233) ; Ternate (model, Leiden) ; Halmahera : Weda Bay (Fr., II, p. 242, Fig. 27), Ake Selaka (Fr., pp. 240, 243, Figs. 17, 22, 23), Patani and Buli (two booms, often with a central false-boom, Fr., p. 242), Tobelo and Galela ("greatly predominates," Fr., pp. 240, 242); Xulla, or Sula (K. Martin, 1894, p. 233 ; Fr., III, p. 161 ; Hornell, p. 99) ; Buton (Fr., pp. 235, 239, Fig. 4) ; Celebes : Makassar (R. Martin, 1894, p. 233); Gowa (model, Leiden); Konawéha River, South-east Celebes (Sarasin, I, p. 376, photo, but no description); Malili River, at the north-east corner of the head of the Gulf of Boni (Grubauer, Figs. 8, 10) ; Gulf of Gorontalo or Tomini : Pogoyama (G., No. 242), Todjo, Gulf of Tomini (Adriani and Kruyt, No. 9, Chap. 5); Minahassa (Dumont d'Urville L'Astrolabe, Atlas; Pls. 192, 204), Kema (G., No. 232), Limbé Island (Guillemard, Pl. p. 325) ; Menado (Hornell, Pl. G, B, and Fig. 3 ; models, Leiden); Tontoli (Toli-Toli), North-west Celebes (Pflüger, p. 85).

Although they are nominally beyond the scope of this paper, the outrigger canoes of North-west New Guinea must be alluded to as they differ from those of other parts of New Guinea and undoubtedly are of direct Indonesian origin, and can be perfectly matched by a type from Weda Bay in Halmahera (Fig. 6). So far as I can gather, but one type of outrigger extends from Skroë to Waigiu and possibly to Manukwari (Dorei) at the westerly opening of Geelvink Bay, where and further east it is replaced by other attachments.

At Skroë (a port founded by the Dutch in 1899 on the north shore of Telok Kampauer, i.e., on the south side of Onin Peninsula), judging from Pflüger's small and indistinct photograph (p. 171), the double outrigger has four booms, the two fore 
and the two aft of which are nearer together than are the two central ones; there is a Halmaheran attachment of the Waigiu type. Apparently, according to Pfluger's photographs (pp. 174, 175) a similar type occurs at Sĕkar (Segaar) on the south shore of Telok Berow (Berou) or McClure Inlet, i.e., on the nortb side of Onin Peninsula; Kreiger says they have very high boats with outriggers (p. 385). Dr. Guillemard's photographs (G., Nos. 305, 427, and 1889, p. 373) of canoes in Chabrol Bay, Waigiu (Waigéŭ), shows the same type of canoe as that recorded by Friederici (II, p. 248, Figs. 29, 30 ; Hornell, p. 99) at Saonek, an islet near the south coast of Waigiu and among the Sorong (Sorŏn) people on the island of Dom, who removed there in 1865 from Sorong, a village near Cape Spencer, or Kaap Noi, on the mainland of New Guinea (Fr., II, p. 248, Fig. 28 ; Hornell, p. 99). The dug-out or plank-built canoes have double outriggers. In the interior of the hull are transverse struts and lateral longitudinal spars as at Manukwari and Japen (Jobi) in Geelvink Bay to the east and at Halmahera to the west. The sides of the larger canoes are heightened by superimposed wash-strakes, and not by gabbagabba as in further east. The four booms of the outrigger stretch across the wash-strakes, to which they are lashed by means of ledges ("Leisten" or patnati), but in small canoes they rest directly on the edges of the dug-out. The two floats may be shorter than the hull, or, as in Sorong, like sledge-runners, and, as in Tahiti, run far forward, the last attachment spar being near its aft end. There is a Halmaheran attacbment of a long fairly straight spar with a bent end, sometimes it is an elbowed spar; an inner longitudinal spar passes over the four booms and underneath the angle of the spars. Friederici figures an attachment at Saonek with an additional outer longitudinal spar, the float in this instance is composed of two bamboos instead of the usual single one. The larger craft have a platform with side rails and an atap roof. On the booms, on both sides of the canoe, there are usually forked supports for gear, which have a crescentic or other form ; on one side lies the unshipped triangle-mast and on the other the rolled-up sail (Fr., II, p. 248).

\section{C.-Mixed Attachments.}

In the foregoing accounts the attachments are similar on all the booms of a canoe. I now proceed to give examples of mixed attachments.

The mixed direct attachment and mixed direct and Balinese attachment have already been described (p. 84).

Mixed Direct and Rod Attachment.-Prichett (p. 175) gives a drawing (Fig. 18) of a sailing canoe, sukung, from Probolingo, Madura Strait, in which the fore boom appears to be a boom-prolongation which is lashed to the float, or it may be that the boom is in one piece, but its diameter markedly varies in parts. The same applies to the aft boom except that the boom-prolongation is thicker and is upwardly curved with a swollen end, this is connected with the float by means of a rod which may be lashed to the boom or may pass through it; the lower end appears to be inserted 
into the float, but the drawing is not decisive as regards these two points. In referring to the " outrigger supports" he says, "The one forward being low down and

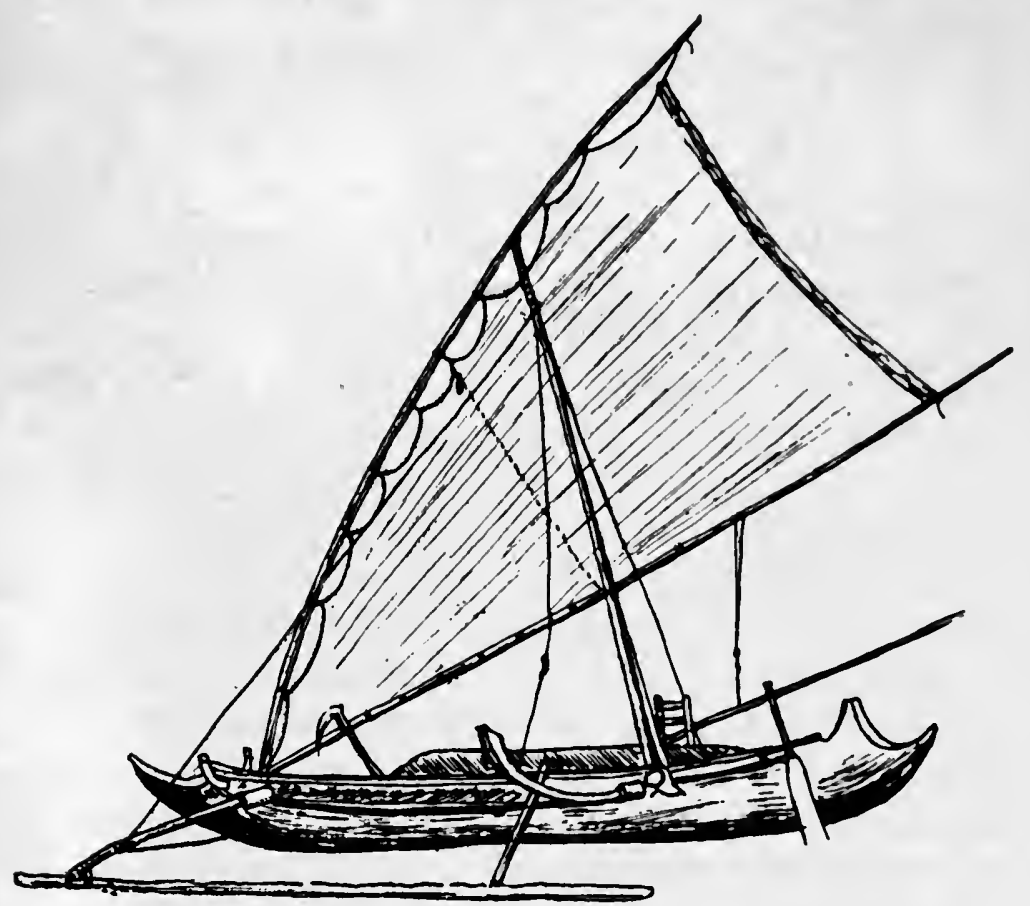

FIG. 18.-FISHING BOAT, sukung, WITH MIXED DIRECT AND ROD ATTACHMENT, PROBOLINGO, MADURA STRAIT (PRITCHETT, p. 175).

that aft curving up pronouncedly, to allow the wash to pass under freely when the vessel is at her high speed" (p. 174).

A model (Fig. 19) of a sekong in the Rotterdam Museum from Pasuruan, in Madura Strait, seems to clear up the points that are doubtful in Pritchett's drawing. Both of the short booms have a boom-prolongation, the fore one is lashed to the float, the

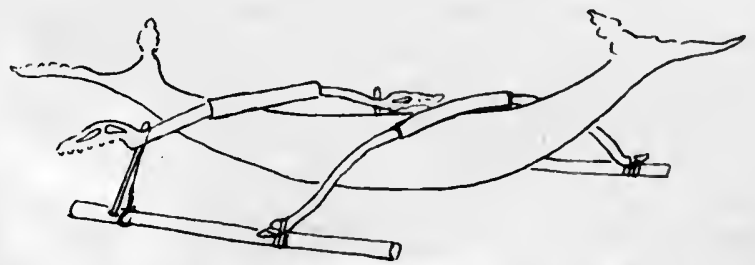

FIG. 19.-MODEL OF A sekong WITH MIXED DIRECT AND ROD ATTACHMENT, PASURAN, E. JAVA (ROTTERDAM).

free end of the aft one is expanded and decorated with fret carving, a rod passes through this boom-prolongation and is inserted into the float, a lashing also connects the boom and the float at this spot. 
In a sketch by Müller (1912, p. 244, Fig. 22) of a canoe from Madura (Fig. 20), the fore boom is a doubly bent yoke-shaped bar, the ends of which are lashed to the floats; the aft boom, or boom-prolongation, is strongly curved upwardly, being almost $U$-shaped, each divergent limb being connected by means of a vertical $T$.
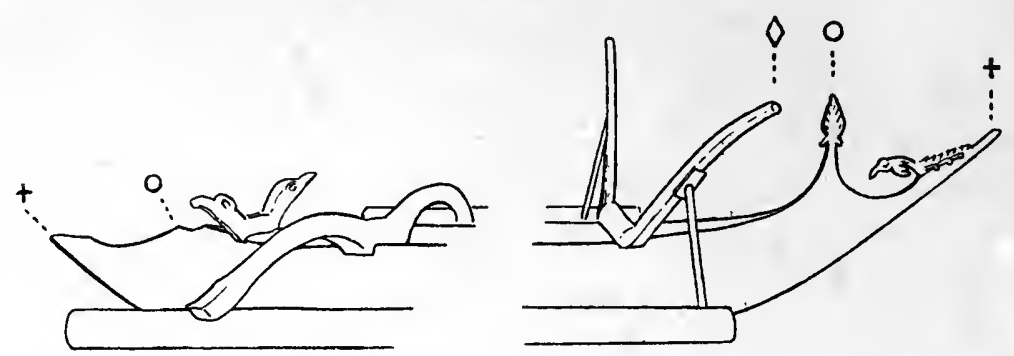

FIQ. 20.-SKETCH OF A MIXED DIRECT AND ROD ATTAOHMENT, MADURA (FROM MÜLLER, 1912, fig. 22).

shaped rod with the float; the transverse upper end of the rod is presumably lashed to the boom and probably its lower end is inserted into the float. Thus in all the main points the outrigger agrees with that of the Probolingo boat.

The same author gives a sketch (Fig. 21) of a canoe from the Bawean Islands ; the fore boom is straight, how it is attached to the float is not evident, but it is a direct attachment. The author states that at the stern the bamboo floats are suspended without spars (Auslegerstange) from an elastic bent rod which is concave above (p. 244). If, as his sketch indicates, this rod is all in one piece, it must be made of bent ratan, as it is inconceivable that the whole apparatus could be made out of

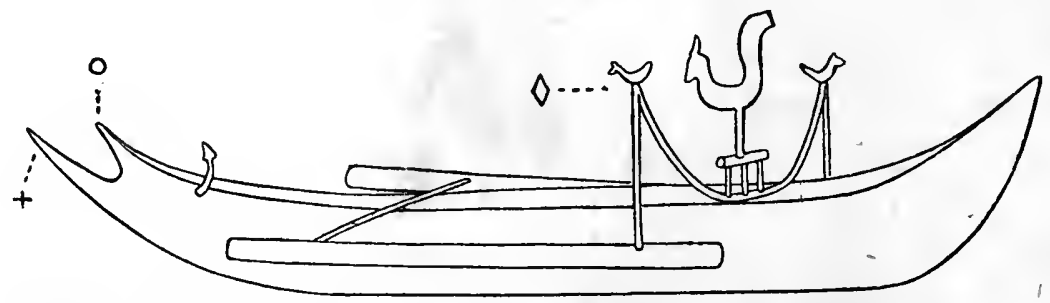

FIG. 21.- SKETCH OF A MIXED DIRECT AND ROD ATTACHMENT, BAWEAN ISLANDS (FROM MÜLLER, 1912, fig. 23).

a single piece of wood. In either case the form requires explanation; we may therefore suppose that it consists of the characteristically upwardly curved boom or boom-prolongation to each end of which a vertical rod is fastened, the lower end of which is apparently inserted into the boom; if this be so, it falls in with the previous examples. Müller states that he made these sketches whilst on board a steamer.

Mixed Direct and Halmaheran Attachment.-In the region embracing North Celebes, Banka, the Talaut (including Sangir) and Tulur Groups canoes have two outriggers and many of them have but two booms. 
Friederici says: "In Minahassa there are outrigger boats whose fore boom is curved and-exactly as in Bali, Bugi, Makassar, at the Mariannes, in Tahiti and at the Marquesas-is fastened directly to the float, while the aft straight boom is connected by means of an S-shaped spar with the float, sema. According to the description of Graafland (Minahassa, II, pp. 404, 405) this might be considered as a Moluccan attachment, but it is really, as Dumont d'Urville's drawings (Atlas, Pl. 234, Figs. 1, 2) prove, the Halmaheran attachment" (III, p. 161).

Hickson gives a figure of a model of a sailing dug-out, londi, from Talisse in the Banka Strait (Fig. 1, p. 22). The fore boom is strongly curved and its ends are lashed to the floats which are generally made of two or three pieces of thick bamboo firmly lashed together. The aft boom is straight and its ends are connected with the floats

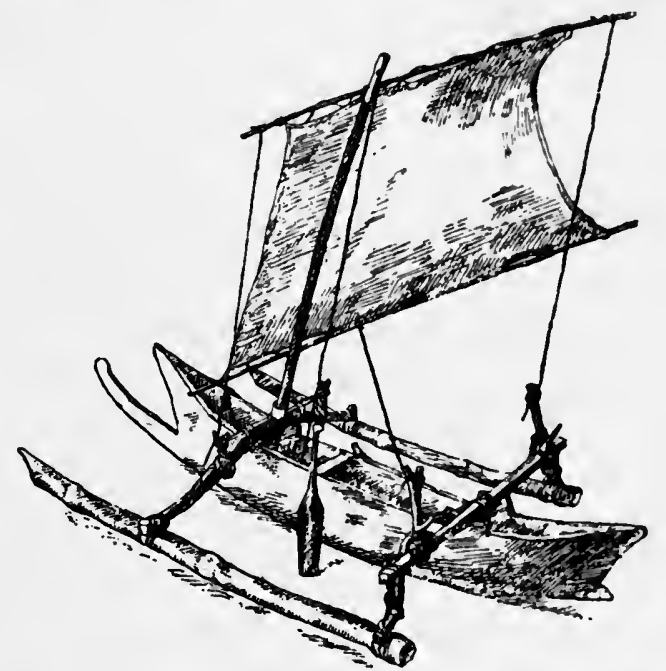

FIG. 22.-SAILING CANoE, londi, WITH MIXED DIRECT AND HALMAHERAN ATTACHMENT TALISSE ISLAND, N.E. CELEBES (HICKSON).

by means of an S-shaped Halmaheran attachment (Fig. 22). In some dug-outs at Kema, slightly to the south of Banka Strait, the fore-boom is downwardly curved with a direct lashed attachment, and the shorter straight aft boom is attached to the float by a bent Halmaheran spar (G., No. 67).

A model canoe from the Talaut Islands in the Amsterdam Museum has two straight booms, of which the fore one has a direct tied attachment and the aft one has a bent or bowed spar attachment, but in this case the free ends of the spar are lashed to the boom and the bend to the float, it thus bears some resemblance to the $U$. Moluccan attachment (Fig. $16 \mathrm{E}$ ). It may be a spar of this kind to which Graafland refers.

In Sangir, according to Müller (1912, f.n., p. 244), the two outer (fore and aft) booms of the double outrigger and their boom-spars bend downwards and are 
connected directly with the floats, whereas the central booms have the structure shown in Fig. 2, D, and have a $\perp$-shaped attachment spar, the lower end of which is lashed to the double floats.

There is a very remarkable model in the Oxford Museum, which was collected by Capt. J. P. Maclear of the "Challenger." The dug-out has notched ends, the upper part being prolonged into a short upwardly slanting beak, the lower part of the bow is produced into a long spur which rises in a gentle curve. There are two floats on each side, each of which has the ordinary pair of booms; the two fore booms lie very close together, as do the two aft booms. The fore booms have a direct lashed attachment. The outer float is attached to its aft boom with a bowed Halmaheran attachment, while the inner is attached to its aft boom by a ${ }^{- \text {-shaped Halmaheran }}$ attachment. The forks on the booms have three branches, one long and low down (like the brow tine of a deer's antler), the other two short and terminal. The fore forks are lashed to the stouter and hinder of the two fore booms, i.e., the one attached to the inner float; a spar rests on the lowest branch of the fork and is lashed in its middle to the socket of the mast. The inner boom is secured by two lashings within the hull of the canoe to a cross-bar, the ends of which are kept in place by passing below projections left in the inner sides of the hull. The mast is stepped in a socket consisting of a section of bamboo, the upper end of which is lashed to the hinder fore boom, while the lower end is steadied by a cross-bar passing through it, the ends of which abut against the inner sides of the hull. I do not know of any other example of two floats on each side each with its own attachments, the double, treble or multiple floats previously noted (p. 83 , figs. 1, 2 D, 15 B), are treated as if they were simple floats. There can be no doubt that the specimen came from the North Celebes area, possibly from the Talaut Group, or possibly from the Nanusa Islands as the ends of the canoe resemble those of the sakit canoes described by Hickson ( $c f$. pp. 77,113$)$.

Mixed Rod and Halmaheran Attachment.-A photograph (G., No. 232) at Kema, Minahassa, North-east Celebes, shows a canoe with attachments which are distinct from any other known to me. At both ends of the canoe there is a framework consisting of a short straight boom, on which is an equally short upwardly curved spar, or boom-spar, these are braced by two vertical sticks. At what is presumably the fore end of the canoe there is a vertical rod which is fastened to the ends of its boom

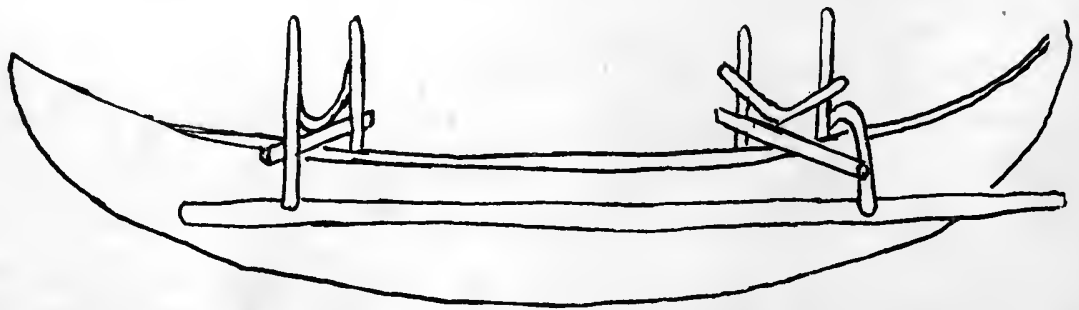

FIG. 23.-MIXED ROD AND HALMAHERAN ATTACHMENT KEMA, N.E. CELEBES (Рното G., 232). 
and curved boom-spar and appears to be inserted into the float. At the other end the rod is replaced by a bent spar, which appears to be a true Halmaheran attachment, as it is lashed to the float. The first of these attachments somewhat resembles the aft attachment of the Bawean canoe (Fig. 21). This Kema type can easily be resolved into the Sangir type (Fig. 2, D) if the booms and upwardly curved boom-spars of the latter were greatly shortened and the oblique sticks or stays were placed vertically. The straight rod also corresponds fairly elosely with the $\perp$-shaped spar of the Sangir type, except perhaps for its attachment to the float.

\section{Notes on the Characteristic Outrigger Canoes of the Main Districts of} INDONESIA.

The outrigger canoes of the Andamans and Nicobars have been sufficiently dealt with on pp. $79,80,85,86$. The main point to remember is that in both groups there is an inserted stick attachment, but in the Andamans the single outrigger bas several booms, while in the Nicobars it has but two.

There is a marked absence of outriggers from the greater part of Sumatra and Java and from the whole of Borneo, which is evidently due to a knowledge of the art of building sea-going plank boats and ships, which have supplanted the older types, as has occurred in the Kei Islands. The general absence of outriggers from the small craft of the harbours and rivers of Borneo is not so easy of explanation. I feel considerable hesitation, however, in making definite statements concerning the distribution of outrigger canoes in certain areas, as I have been able to find very little positive evidence one way or the other, and negative evidence is full of pitfalls.

According to Modigliani, canoes are very rare in Nias, and he does not mention an outrigger $(1890$, p. 418$)$; other authors do not appear to mention them either.

Rosenberg (1878, I, p. 176) figures a canoe, $a b a k$, from Mentawei, with a single outrigger, two booms and a direct lashed attachment. The Mentawei war-ship, knabat bogolu, figured by Rosenberg (1888, Pl. VIII, Fig. 9), is referred to on pp. $74,78,83$; it has apparently a single outrigger which is on the starboard side and a direct lashed attachment.

Modigliani describes the simple but seaworthy canoes, eloha, of Engano; they are dug-outs with a double outrigger which rests in four deep notches in the gunwale (1894, p. 206). A model in the Leiden Museum shows two booms and floats far away from the hull with a direct tied attachment. Giglioli, in describing the specimens collected by Modigliani, says: "These are long narrow dug-outs [cobara-eloha], made from a single tree-trunk, with two outriggers ; the cross-pieces or seats are often beautifully carved, the usual figure being that of a man with arms and legs extended as if to keep apart the sides of the canoe; grotesque figures in-coitu or that of a frog being swallowed by a snake are amongst the specimens of these quaint Engano 
boat seats. No sails are used, and the paddles are plain and of the usual type" (1893, p. 131).

At the present day, outriggers appear to be scarce in Sumatra. Friederici (II, p. 235) states that outriggers have almost disappeared in the Singapore, Banka and Biliton areas. Dampier narrates in his Voyages that the Nicobar canoe in which he sailed to Achin had "good outlayers lashed very fast and firm on each side the vessel, being made of strong poles. So that while these continued firm, the vessel could not overset . . . we were therefore much beholden to our Achinese companions for this contrivance" (quoted from Kloss, pp. 267, 268). This was in 1688; that the " outlayers" were true outriggers and not outlayers (p. 76) seems probable, as in his description of his visit to the Nicobars, Dampier speáks of the "small slight outlayers on one side" of the local canoes (loc. cit., p. 260), and, as we have seen (p. 78), the Nicobarese canoes have single outriggers or none at all. Folkard (p. 480) refers to the long narrow jellore and ballelang of Sumatra which " are fitted with double outriggers, which stand out a considerable distance from the sides." He figures a jellore with the sail partly furled, the ends of the two booms curve downwardly and apparently are inserted into the floats. Folkard does not say where he saw these craft, probably it was on the coast of the Palembang district; he adds, "jellores have sometimes only one outrigger." Other sailing vessels without outriggers are the panchallang and the bantang. In the Amsterdam Museum there is a model of a canoe from Palembang with a double outrigger, two booms and a direct tied attachment. Giglioli (1893, p. 116 and Fig. 8) describes the Batak solu dug-outs with a wash-strake but no outrigger; the bow and stern decorations are noteworthy, they consist of sticks with tufts of hair and a central phallus; the bow in addition has a wooden carved and painted buffalo head. Brenner (1894, p. 284) refers to two kinds of keel-less dug-outs among the Batak of Lake Toba, the solu ratsaran or fishing canoe, and the solu bolon for trade and war; some of the latter, he says, are provided with an outrigger, but he gives neither an illustration nor a description. Fischer (p. 114) refers to a model in the Leiden Museum of a sail boat, djongkang, from Padang, with a double outrigger of two feeble bowed booms; Dr. Juynboll informs me that these are half inserted and attached by a nail to the float.

Hornell's observation that North-Central Java is a locality where the outrigger pattern of canoe has long been discarded in favour of properly built boats (1919, p. 98) supports Friederici's remark that outriggers have almost disappeared from the Javan coasts (II, p. 235). References have been made (pp. 82, 87) to a degenerate canoe from North Java described by Hornell.

There is a distinct type of attachment in the Eastern Javan area (Madura Strait, Madura, and the Bawean Islands) which has already been described (pp. 92-94, Figs. 18-21). Müller remarks (p. 244) that the Bawean and Madura boats are quite isolated in the western archipelago, and only find affinities in the extreme east in the 
South Philippine local group. In both areas the fore boom has a direct attachment, while the aft boom has an indirect attachment. Müller takes the Sangir model (Fig. 2, D) as a parent type from which the Eastern Javan and South Philippine types have diverged, and appears to regard the upwardly curved aft booms of the Javan boats as the equivalent of the upwardly curved "Bügel" (boom-spars, p. 73) of the South Philippine area (Figs. 2, A, and 7). It seems to me much more reasonable to regard them as true booms, or boom-prolongations, which are recurved, and not as reduced boom-spars of the Sangir model, of which the outrigger-boom and oblique stays have disappeared. In my opinion a much closer analogy is to be met with in the Northern Celeban types illustrated by Figs. 22 and 23, the main difference being that in the latter the attachment spar is tied to the float as in the ordinary Halmaheran attachment, whereas in the Eastern Javan type the attachment rod appears to be always inserted into the float. The rod-attachment of the Kema (North Celebes) canoe is associated, as we have seen (p. 96), with a Halmaheran attachment. The Eastern Javan area is contiguous to and partly overlapped by that of the Balinese attachment (p. 88). Juynboll describes (p. 37) a model in the Leiden Museum of a trading vessel (Madura, paduwang from East Java) with a double outrigger of two booms which are tied to the float.

In Madura and Bali the attachment may be direct and lashed (p. 83). In Madura Strait the straight fore-boom may be lashed to and the curved aft boom inserted into the float-i.e., a mixed direct attachment (p. 84). Typical of Bali is the Balinese attachment, which consists of a spar rigidly fastened by one end to the boom, the other end being inserted into the float; it also occurs at Lombok (p. 88). A mixed direct lashed and Balinese attachment occurs at Madura (p. 84). A mixed direct lashed and rod-attachment occurs in Madura Strait and at the Bawean Islands, the rod being lashed to or inserted through the boom and inserted into the float (p. 92).

We may thus define an Eastern Javanese area which includes the extreme eastern end of that island, Madura, Bawean, and Bali, and is characterized by the occurrence of attachments which form a gradation of types : (1) In Bali both booms have the sedek. (2) The fore boom is lashed directly to the float; the aft boom is (a) inserted into the float, (b) a prolongation of it, the sedek, is inserted into the float, (c) a rod is inserted into the float and inserted into or lashed to the boom, or $(d)$ the aft boom is lashed directly to the float. It is always risky to suggest an evolutionary series, but it looks as if an inserted direct attachment, here usually under the modified form of the sedek, might have been the earliest form for both booms. The greatest strain in an outrigger is at its fore end, and a lashed attachment might have been adopted to counteract this, while the assumed primitive form would be retained for the aft boom; it will be noted that a lashing is provided for the sedek for greater security. The rod attachment is probably a modification of the sedek. It would only require that the rod should be lashed to both the boom and the float to convert 
it into a simple form of Halmaheran attachment. The lashing would give at the same time greater strength and elasticity and probably less liability to fracture.

The colonization of Java from India, according to Havell, was probably a sequence of the final collapse of the Sâka power in India at the beginning of the fifth century, when the kingdom of Sarāshtra or Kathiāwār, which had been ruled for centuries by the Sâka dynasty, of foreign origin, was conquered by Chandra-gupta II (Vikramāditya) between A.D. 388 and 401. This great monarch, although tolerant of Buddhism and Jainism, was himself an orthodox Hindu (V. A. Smith, p. 292). "After that Brahmanism supplanted Buddhism as the principal State religion of India, the Buddhist art traditions went with the Sâka immigrants to Java, where they reached their highest expression in the magnificent sculptures of Borobudur" (Havell, p. 113).

" 'It having been foretold,' say the [Javanese] chronicles, 'to a king of Kúj'rat, or Gujerat, that his kingdom would decay and go to ruin altogether, the Prince resolved to send his son to Java . . . and embarked him with about five thousand followers for that island. Among these followers were people skilled in agriculture, artificers, men learned in medicine, able writers, and military men. They sailed in six large ships and upwards of a hundred small.' [This was in A.D. 603. Later on a reinforcement was sent of two thousand people.] 'From this period,' continue the chronicles, 'Java was known and celebrated as a kingdom; an extensive commerce was carried on with Gujerat and other countries. . . . During the sovereignty of the Prince and his two immediate successors, the country advanced in fame and prosperity . . . artists especially in stone and metals arrived from distant countries' and temples were constructed . . . ' and at Borobudur in Kedu during these periods by artists from India.' . . . The building of the splendid shrine of Borobudur, the most magnificent monument of Buddhist art in the whole of Asia, is ascribed to circa A.D. 750 to 800 , but the decoration of it must have spread over several centuries. It was not in fact entirely completed before the Buddhist faith in Java was superseded by orthodox Brahmanism as the State religion, about the tenth century" (Havell, pp. 111, 112). C. Leemans, however, states that, according to the annals of Java, Brawidjaja of Kalinga founded the Empire of Mendang Kamoulan in Java. This prince arrived in the year 525 of Sâka (A.D. 603). What transferred the religion of Hindustan to Java was not war, these were not conquests, it was commerce and navigation (p. 541). The fall of the Empire of Borobudur took place towards the end of the tenth century (p. 537).

Assuming that there was a large organized expedition from India to Java in A.D. 603, it presupposes a knowledge of the island and of its suitability for colonization, and for an undetermined time previously there must have been voyages to and fro. At all events, we can date the sculptures of the ships at latest within the eighth and tenth centuries and the types of the ships may have been common much earlier. These carvings are of especial value in the present connection as they are the earliest 
records of outriggers, of which several varieties were fitted to these ocean-faring plank-built ships.

Representations of seven ships are given in Leemans' atlas of "Bôrô-Boedoer" (some of which have been copied by Radhakumud Mookerji), two of which are without outriggers, one having a simple mast and the other a tripod one. The other five ships have outriggers which we may suppose were double, as four show a port outrigger, and one a starboard outrigger. Four have two masts, the other (26) has a single one ; one (24) clearly has a double or bipedal mast, and in others it is possible that there may be bipedal or tripod masts, but the details are obscure. In two a single series of rungs project from the single or both masts, and also in the aft mast of another (27), but in this ship the foremast has two rungs. In one ship (28) the rungs appear to abut against rope, it is possible they may have been connected with it.

Three ships have three straight outrigger-booms, another (27) bas four booms, while the three booms of the fifth (28) do not appear to be straight. All these booms pass below or over a gunwale board. In two ships $(26,27)$ the straight booms pass

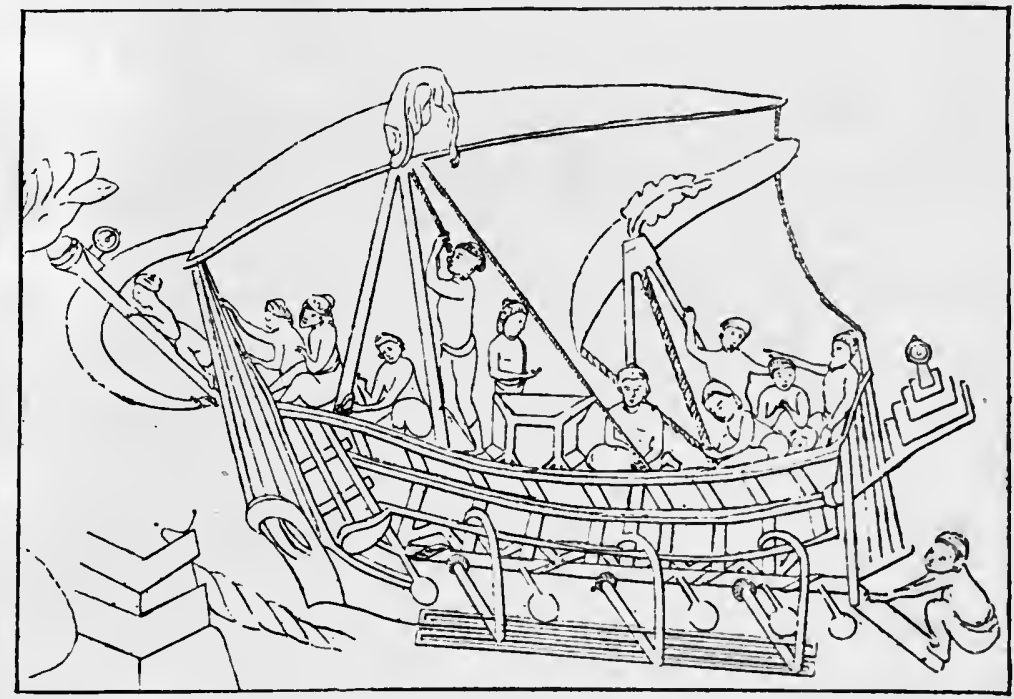

FTG. 24.-INDO-JAVANESE SHIP: TWO BIPED MASTS, THREE STRAIGHT BOOMS WHICH PASS BETWEEN THE TWO LONGTTUDINAL SPARS AND OVER THE DOUBLE FLOAT, THREE CURVED BOOMS WHICH PASS OVER THE TWO LONGTTUDINAL SPARS AND OVER THE DOUBLE FLOAT (LEEMANS, pl. ciii, 176).

below the single longitudinal spar, in two $(24,25)$ they pass between the two longitudinal spars. In two ships $(25,27)$ the euds of these booms lie well above the float, in one (26) they appear to pass behind the inner element of the double float, and in a fourth (24) they appear to pass in front of botb elements.

In four ships, in association with the straight booms are an equal number of downwardly curved booms, which usually pass over the gunwale board and under 


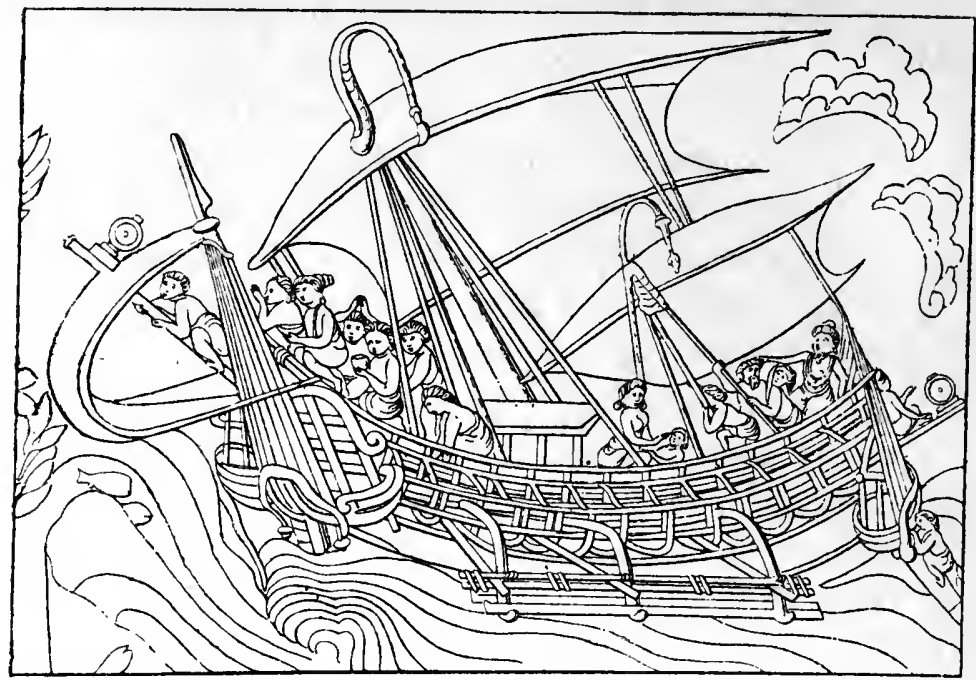

FIG. 25.-INDO-JAVANESE SHIP : TWO MASTS, THREE STRAIGHT BOOMS WHICH PASS BETWEEN THE TWO LONGITUDINAL SPARS, THREE CURVED BOOMS WHICH APPEAR TO PASS BETWEEN THE LONGITUDINAL SPARS, THEY PASS BETWEEN THE TWO ELEMENTS OF THE DOUBLE FLOAT AND CURL UP TOWARDS THE UPPER ASPECT OF THE OUTER ELEMENT OF THE FloAT (LEEMANS, pl. ci, 172).

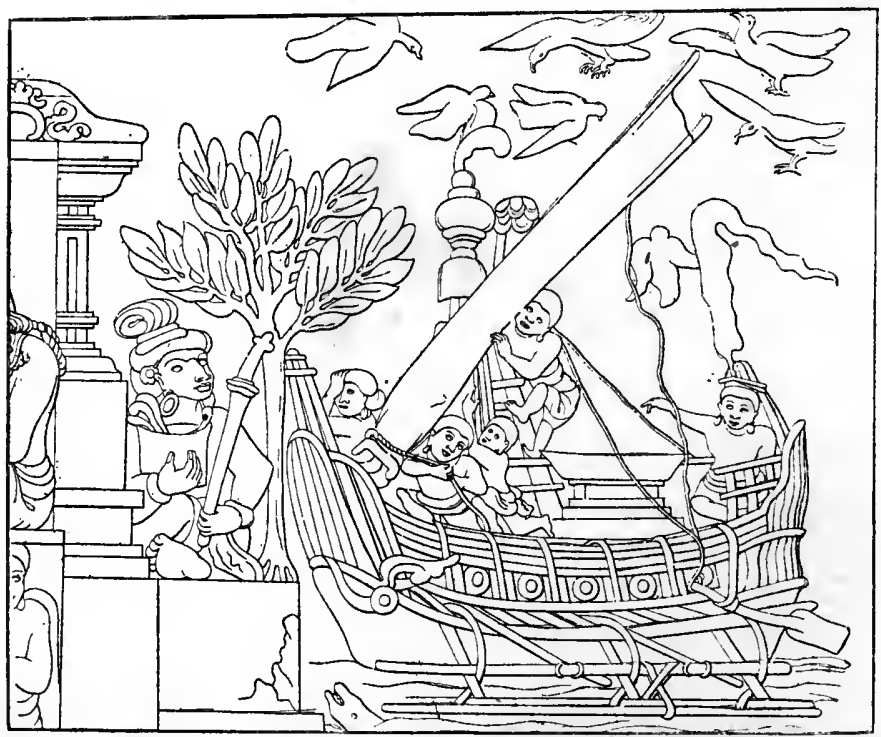

FIG. 26.-INDO-JAVANESE SHIP : ONE MAST WITH RUNGS, THREE STRAIGHT BOOMS WHICH PASS BELOW THE LONGITUDINAL SPAR AND APPARENTLY BELOW THE DOUBLE FLOAT, TWO FALSE BOOMS, THREE CURVED BOOMS WHIOH PASS OVER THE LONGITUDINAL SPAR AND BETWEEN THE TWO ELEMENTS OF THE FLOAT (LEEMANS, pl. ccli, 41). 


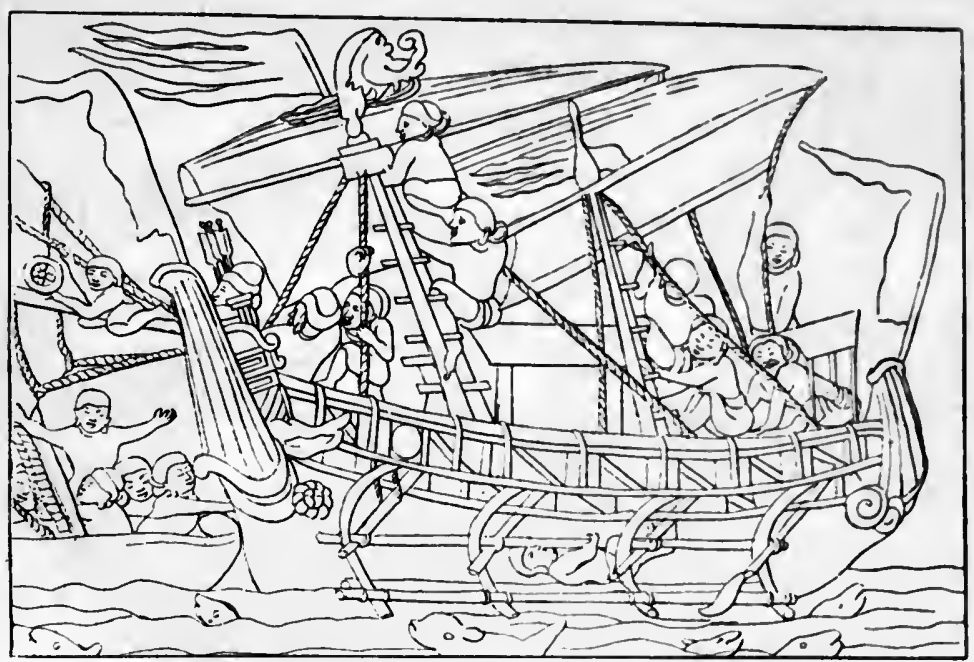

FIG. 27.-INDO-JAVANESE SHIP : TWO MASTS WITH RUNGS, FOUR STRAIGHT BOOMS WHICH PASS BELOW THE LONGITUDINAL SPAR, FOUR CURVED BOOMS WHICH PASS OVER THE LONGITCDINAL SPAR AND BETWEEN THE TWO ELEMENTS OF THE DOUBLE FLOAT AND PROJECT BEYOND THE oUter of these (Leemans, pl. cxxiii, 216).

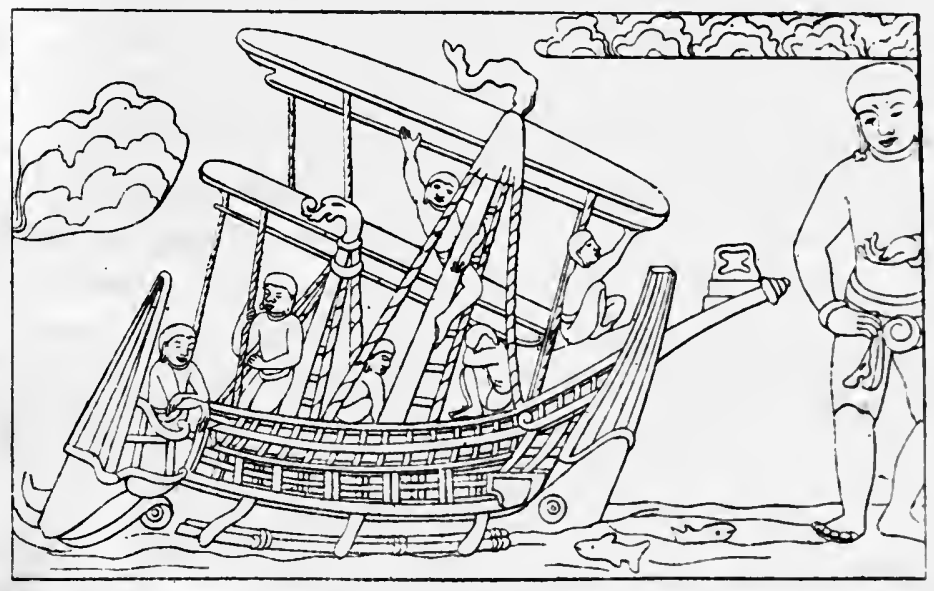

FIG. 28.-INDO-JAVANESE SHIP : TWO MASTS WITH RUNGS, THREE BOOMS WHICH ARE PROBABLY SHGHTLY CORVED, THEIR ENDS ARE PRESUMABLY LASHED TO THE DOUBLE FLOAT (LEEMANS, pl. Ixviii, 106).

another board or rail. When one longitudinal spar is present $(26,27)$ they curve over (in front of) it, or if there are two longitudinal spars they curve over both in one and doubtfully over the inner and behind the outer (i.e., they pass between them) in the other. In two cases $(25,27)$ the curved booms pass between the two elements of the double float and curl under and more or less to the front of the outer element ; 
in anotber (26) they simply pass between the two elements of the float; in the fourth (24) they pass in front of both elements.

In the fifth ship (28) the longitudinal spar is absent and the ends of the slightly curved three booms pass to the outer side of the double float, the two elements of which are shown as being tied together-I regard these three booms as the equivalents of the curved booms, the straight booms being absent.

In one (26) of the two ships with a single internal longitudinal spar, this spar is further supported by two false booms to which it is tied, and a central lashing passes between this spar and the float, embracing both elements of the latter. These contrivances frequently persist in Indonesian canoes.

It is very difficult to arrive at a satisfactory conclusion as to the construction of these vessels and to the real nature and structure of the outrigger. One gets the impression that the sculptors did not really understand the details of the working drawings, which evidently were supplied to them. Probably they were artists who had no practical knowledge of sea-craft ; further, there were technical difficulties to be overcome in representing so complex an object as a two-masted sailing ship with its gear in relatively low relief, and it is amazing they did it so well.

It is evident that the straight booms, curved booms, and longitudinal spars must have been lashed together, and the ends of the curved booms to the float, but these usually are not indicated.

The straight booms in two ships resemble the booms of existing boats with a Halmaheran attachment, in two others they appear to reach the double float, but whether they were actually lashed to it is uncertain. The most problematical of these is Fig. 24, here the curved booms apparently meet the straight booms on the float ; it bears a superficial resemblance to Rosenberg's model of a sailing canoe from the Mentawei Islands (Fig. 1), the double float of which is apparently lashed to one boom coming out horizontally from the gunwale of the canoe and to another slanting down from the roof of the cabin ; it is possible that this slanting boom or "boom spar" may correspond with the curved boom of the carving; the model lacks the longitudinal spars which I regard as being present in the Indo-Javan vessel.

What is the nature of the curved booms? At first sight they appear to be fairly typical Halmaheran attachments, but, on the other hand, in three cases they seem to come out of the side of the vessel, but this is not so markedly the case in the fourth case (Fig. 24). If they come out of the vessel they may be regarded as true outriggerbooms, somewhat analogous to the central booms of the Sulu canoes, or as the curved booms of Pritchett's "pirate craft" (Fig. 8), but if this be so the straight booms have to be accounted for. If the curved booms are the essential booms, then the straight ones may have been intended simply to strengthen the outrigger. We must remember that these craft were ocean-going sailing vessels, and consequently the outrigger had to be very strong.

Owing to the kindness of L. W. Jenkins, of the Peabody Museum, Salem, Mass., 
I am able to illustrate (Fig. 29) a canoe model from Nonuti (Nanouti) Island, Gilbert Group, which has a single outrigger of three curved booms, which are attached to the float in the same manner as that of the Funafuti canoe (Fig. 33). There are in addition two straight booms which are lashed on to the short longitudinal spar.

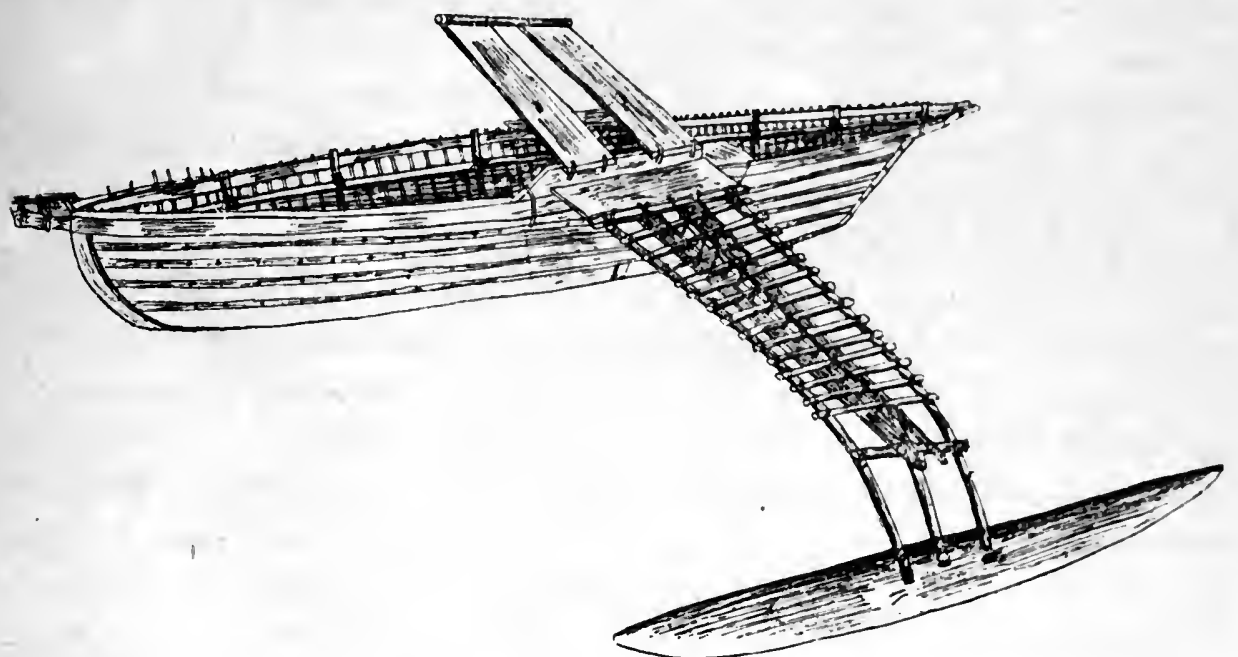

FIG. 29.- SKETCH FROM A PHOTOQRAPH OF A MODEL OF A CANOE WITH THREE CURVED BOOMS WITH A DIRECT LASHED ATTACHMENT AND TWO STRAIGHT BOOMS, NONCTI (NANOCTI) GILBERT GROUP (SALEM).

The other spars on the curved booms form a platform. There is also a "weather platform." This model supports the suggestion that the straight booms of the Indo-Javanese craft merely supported the curved booms, which appear to have been the essential ones. In the Marshall Group (pp. 81, 126) the two straight booms are supported by inserted sticks.

I have already suggested how a Halmaheran attachment might arise from an inserted rod-attachment (p. 99). Granting a pre-existing Halmaheran attachment, when the size of the vessel was increased, its upper part of the attachment may have been prolonged so as to enable it to be secured firmly to the hull of the vessel, as appears to be the case in some of these carvings. One other alternative presents itself : it is possible that the Halmaheran attachment may be derived from a curved outrigger-boom. With the increase in the size of the vessel and the assumed addition of a straight boom to strengthen the outrigger we get the apparently typical IndoJavanese arrangement. If lighter vessels were built the straight boom might persist and only the curved terminal portion of the curved boom be retained; it would then become the means of connecting the straight boom with the float.

Whence did these sea-faring vessels which bore Indian immigrants to Java obtain their outriggers? At the present time the South Indian outrigger is composed solely of two booms with a direct tied attachment. The earliest evidence on this 
point I have been able to discover is the drawing given by Lintscotus (II Pars, XCIX, Pl. XIV, D 3) of a boat from Goa and Cochin with a single outrigger of two booms which rest on the gunwales and on the flat upper surface of the large float. The method of fastening is not clear ; it may be by. means of staples, but more probably by sinnet lashings, in which case those of the float would pass through undercut holes. This negative evidence is by no means conclusive. If the bent booms of the Javan ships be true booms then they might be compared with the modern South Indian outriggers, except for their number and the curled lower ends supporting the float. The number presents no difficulty as the larger size of the Javan vessels would necessitate this. So far as I am aware, the arrangement by which the float is supported by the ends of the curved booms is unique, though the three central booms of a model from Gowa, South Celebes, are lashed to the underside of the float (p. 84).

If the curved booms be an enlarged Halmaheran attachment, it follows either (1) that this method was invented in India, or (2) that it originated in Indonesia and was adopted by Hindus for vessels sailing in this region. As previously noted, the great expedition of A.D. 603 surely indicates that the country to which they voyaged was well known to the leaders, probably through centuries of trading intercourse, and if the outrigger was already established in Indonesia it would not be surprising that the local Hindus adopted so practical a device to render their large craft more seaworthy. An additional argument for Indonesian origin is supplied by the presence of the longitudinal spar, wbich was sometimes connected with the float by a lashing.

In 1596, according to $\mathrm{L}$. ( $\mathrm{I}, \mathrm{p} .35$ ), the Javan craft consisted of two-masted merchant ships, Ionco ; war vessels : small, with or without a sail, parao, and large sailing cathar ; and small fishing canoes with a double outrigger and direct, probably tied, attachment, while they carried a large sail which gave them marvellous speed.

\section{The Lesser Sunda Islands.}

I have been able to gather but very little information as regards these islands. Bali has already been dealt with. Hornell states (p. 99) that a Halmaheran attachment is common in Lombok, the only instance I know of recorded from the whole group, but Professor S. J. Hickson has given me a photograph of Coupang, Timor, in which it occurs. A direct lashed attachment occurs in Sumba and Lomblen, and the Moluccan at Wetta. At Baba (Babber) there are the direct lashed, Halmaheran? and, judging from an indistinct photograph by Pflüger (p. 146), something that looks like an inserted stick attachment; I cannot make out the details, but if it be so, it is, so far as I know, a unique record for this part of Indonesia, unless the vertical spar of Riedel's model from Tenimber is inserted into as well as lashed to the float: but a true Halmaheran attachment does occur there (Fig. 4).

\section{The Ker and Aru Islands.}

A direct lashed attachment has been seen in a fresh water creek at Totoat, Kei Islands, and a Moluccan at Batu merah, in the south-east. A typical Halmaheran 
attachment occurs at Dobbo (Pulo Wamar), Aru Islands. Doubtless the great development of plank-built boats in this region has had an inhibiting effect on outrigger craft, as has occurred in North-west Indonesia.

From an ethnological point of view the Kei Islands were originally Papuan, as they still are racially to some extent, but they have been so influenced by cultures coming in from the Archipelago that they may now appropriately be considered as essentially Indonesian. The Kei Islanders are noted throughout the Archipelago for their skill in shipbuilding.

Wallace gives a description of the construction of boats by the Kei Islanders and states that they are the best boat-builders in Indonesia (II, pp. 183-186, see also pp. 92, 159). Langen also gives an account of their boat-building and says that they supply boats to the natives of the Aru and Banda Islands (p. 43).

Van Hoëvell thinks that the dialects of the Aru Islands appear to be closely akin to bahasa tanah. Friederici does not find it so, as they, and the dialects of the Kei Islands, have little to do with those dialects, like bahasa tanah, which have a direct culture-historical connection with Melanesia. But, on the other hand, language, ethnography, and mythology show that the natives of the Aru and Kei Islands have a great common substratum with the Alfurs of the Moluccas and Minahassa. An important element in the Kei Islands was formed by fugitives from Banda, as to a certain extent is proved by the characteristics and language of the folk at Eli, Ellat and Fehr in Great Kei (Fr., III, p. 9). The little western island of Dobbo has an annual market which is frequented by traders from all parts; it forms an economic link between New Guinea and Indonesia. The natives are undoubtedly Papuans, but settlements from Indonesia have modified some of the coastal groups.

\section{The Moluccas. ${ }^{1}$}

There are, in the main, three types of craft in Banda and Amboina : (1) the plank boats, (2) the outrigger canoe, and (3) the dug-out.

(1) The beautiful large plank boats, örěmbầ, bave a stem-post, which, as seen from the side, is broader and lower than the stern-post. The orembai of Amboina and Banda have been modified by European influence, but in general reveal the Indonesian original type, this latter persists among the fisbing population and in form and construction resembles the mon of Buka in the Solomon Islands. Friederici gives further details of their construction which do not concern us here.

(2) Outrigger-canoes consist of a dug-out with moderately pointed, almost similar stem- and stern-posts, sometimes with additions. In Banda the sides are often heightened by planks, but in Amboina with a bamboo gunwale. Some Banda canoes have the high beak of the orembai. All have two floats at the end of two booms athwart the hull, the float and boom are attached by pieces of ratan of the thickness of the thumb and lashed with spliced liana or thin ratan. The Moluccan attachment

1 The following account is largely taken from Friederici, II, pp. 235-243, and III, pp. 159-162. 
is described on p. 89. The floats at Banda consist of bamboo, at Amboina of one or two lengths of gabbagabba (the mid-rib of the leaf of the sago palm), side by side. Both kinds are bent up in front like sledge-runners. The aft boom is usually quite near to the aft end of the float, the fore boom is further from its fore end. The booms, which are of light wood, are laid over the edge of the hull, sometimes for strength they are lashed with arenga-string to a pole placed beneath them and between the sides of the canoe. These poles and the booms are tied with lashing of ratan or arenga to ledges projecting from the keel and side planks through the eyes in which the lashing is passed; there is no special name in the Moluccas for these holed ledges, so Friederici adopts the Melanesian term of patnati for them. Sometimes $Y$-shaped wooden forks are lashed to the booms to carry fish-spears, paddles, and other gear. Originally, and still among the primitive fishers of Banda and Ambon, all the parts are sewn and tied together. The commonest names for outrigger-canoe in Banda, Amboina and the neighbourhood are pra $\widehat{u}$ (prahŭ) and hăkă, but in the country-speech of Amboina and the Uliassers are also found tala, talalo, talo, alal, sapu and sapou.

(3) In Banda and Amboina there are also very rude, in part trough-like, dugouts called kŏlěkŏle, which are also called prâu when a clumsy double outrigger is added. Kŏlěkŏle is the same word as kŏrc̆k ră (p. 117).

The Moluccan korra-korra is a vessel of the same construction as a large orembai, but with a double outrigger. The first and best description and illustrations of these was given by Forrest (pp. 23, 67, 83, pls. 4, 5, 10, 12, 15). These craft are especially known in the history of the Moluccas and of Western New Guinea as the constituent part of the notorious Hongi fleets.

In Banda and Amboina a tripod-mast, with a quadrangular sail set obliquely, is in general use. The baler is the concave portion of a large sea-shell, or made of the sheath of a palm-leaf which has the form of the common Polynesian baler. Friederici (II, p. 238) states that the technical nautical terms collected by him at Banda are nearly all Malay or Malayized. Corresponding terms in the language of the old inhabitants of Banda perhaps survive in a single village in the Kei Islands inhabited by descendants of the Banda folk. The Amboina terms are also much Malayized. The old true Alfuran terms occur only in the remote and slightly affected villages of Amboina and the neighbouring islands.

Martin describes an orembai seen by him in Piru Bay, West Ceram (1894, p. 86), and refers to three kinds of craft at Buru : the sarua is used in Kajeli Bay in the east (p. 258); the fakatora is the boat of the Galelaese who live with the Sulanese in different kampongs on the south coast west of Tifu (p. 356), he describes the rig and method of sailing (p. 358); the prau as seen on Lake Wakollo, Buru, is unusual, the double outrigger consists of three slightly curved booms, instead of the customary two, with a direct tied attachment (p. 329).

A direct lashed attachment occurs on Lake Wakollo in Buru. 
The U-Moluccan attachment occurs here and there on Buru ; as the predominant or exclusive form of attachment on Banda, Amboina and the Uliassers; on Ceram, with the exceptions of most places on the north coast; Obi. Friederici speaks of it as sporadically diffused throughout the Northern Moluccas and as being found wherever the bahasa tanah is spoken (III, p. 161). On Amboina the attachment is almost always the O-type, while at Banda the 6-type predominates. At Amboina the float usually consists of one or usually two lengths of gabbagabba (midrib of sago palm-leaf).

The simple Moluccan attachment is confined to Indonesia, but a crossed double variety occurs sporadically in the West Pacific (p. 129), which Friederici believes was carried thither by his Alfuren migration.

Some form of Halmaheran attachment is known from Banda, Buru, on Amboina, the north coast of Ceram, Misol, and at Obi it is more in evidence than the Moluccan attachment. Four booms may occur at Misol (G., No. 267); I do not know whether this is generally the case, but the type of outrigger is precisely like that characteristic of the north-west area of New Guinea. Guillemard (1894, p. 427) states that the fauna is Papuan and that the inhabitants of the interior are true Papuans, but on the coast are a mixed Malayo-Papuan race.

Following Friederici, we may adopt the term Alfur as the historical name for the aborigines, or at all events for early inhabitants of the Moluccas. He enters into a lengthy discussion (III, pp. 1-4) of the modern abuses of that word, a term which merely indicates the ruder inland hill-people as contrasted with the more advanced coast-dwellers, a distinction met with all over Eastern Indonesia, New Guinea, and the larger islands of the South Seas. He also points out that, "these Alfurs of the Moluccas and North-east Celebes are not somatically uniform and their languages belong rather to a linguistic family. Ethnologically they form a fairly uniform layer of an older evolutionary or colonization period than the layer of the coast people ; and also historically they form a positive unity, as in a large measure they appear to have contributed to the Melanesian population of New Guinea and the islands further east" (III, p. 3). He adds : “The Alfurs of Ceram, Ambon, the Uliassers, and Buru, only persisting now in the interior of Ceram and Buru, are physically distinct from the Malay and Malayized population of Mongoloid affinity now occupying the greatest part of the East Indian Archipelago and the Philippines. They are darker than the latter, taller, more powerful, with fine yet strong limbs and joints, and without the flat noses of the Malays, Tagals and others" (III, p. 150). Martin says, "I have no doubt that the highlanders of Buru and Seran [Ceram] are closer to Melanesians than to Malaysians" (1894, cf. pp. $79,119,288)$. Some still live on the coasts in various places as von Rosenberg has found in Ceram (1878, II, p. 26), though the majority as their name implies are "bushmen."

In Buru and Amblau the population has undergone a considerable mixture since the arrival of the Europeans. The coast population of Buru, especially at the Kajeli end, is strongly mixed. Amblau has received immigrants from Nusa Laut and 
Western Ceram. Everywhere here the trade language is Molucca-Malay, or at least it is understood, but the Alfurs of the interior have largely preserved their speech (Fr., III, p. 9).

Friederici (III, p. 7) states that the so-called Ambonese language, bahasa tanah, is split into very numerous dialects on different islands. The Alfurs of Ceram comprise the Patasiwa in the west and the Patalima in the east. This condition formerly obtained in the Uliassers and in Amboina. ${ }^{1}$ Language and tradition show that the Alfurs of Western Ceram and the original inhabitants of Amboina and the Uliassers were one tribe, and till the arrival of the Portuguese formed an ethnological and somatological whole, with only dialectic differences. The dialect of Eastern Ceram reaches also to Goram, thus the bahasa tanah of Amboina, the Uliassers, and of Western Ceram, is manifestly somewhat more remote. Of the dialects of Western Ceram that of the old Huamual (Little Ceram) appears to have been the mothertongue of several others, including that of Amboina; it was the classical, a kind of sacred language (as is the kawi, or Ancient Javanese, among the Javanese). At the time when the Dutch first arrived, Huamual was one great garden, " a Paradise on earth," with 11,000 inhabitants and 2,000 warriors, now it is an awful wilderness in which no human beings live (Riedel, pp. 92, 93 ; Fr., III, p. 8). Fugitives from Banda have mixed with the inhabitants of Eastern Ceram, Ceram Laut, and Goram.

No trace remains of the original inhabitants of the Obi (Ombi) Islands (Fr., III, p. 9).

\section{Halmahera and Neighbouring Islands.}

A direct lashed attachment occurs at Batjan, Ternate. and on Lake Galela in North Halmahera.

The U-Moluccan attachment predominates at Batjan, with a few cases of the Halmaheran attachment; the float is almost always of bamboo as in Banda, sometimes a second is tied beside the first. At Ternate the U-Moluccan attachment greatly predominates (Fr., II, p. 239).

The Halmaheran attachment occurs at Tidor.

In 1599 (Nicolas, II., Pls. 14, 15, 17) there were at Ternate two-masted merchant ships with an outrigger of three booms and a $Y$-board attachment; war-vessels, carcolle, a double outrigger, the largest had a fighting-platform, three booms with the usual $Y$-board attachment and longitudinal planks for paddlers, though others had two booms usually with $Y$-boards, over which was a longitudinal plank for paddlers, or a direct (? tied) attachment, in which case the paddlers sat on the float ; a "gondola," cymbe, with outrigger, two booms and direct attachment; fishing canoes with outrigger, two booms and direct attachment. As I have previously stated, too much reliance should not be placed on these early engravings, but I think it is safe to assume that the outrigger was double in all vessels; we know it was in some,

1 For further information on this dual division and for a suggestion as to its origin, see W. J. Perry, p. 46. 
and probably in all, of the carcolle type. Presumably the direct attachment was tied. None of the old books I have consulted indicate a Moluccan attachment. but it would not be safe to base any definite argument on this negative evidence ; Weule (Pl. 112. Fig. 7) figures a "Boot von den Molukken" with a double outrigger of three booms, beneath the middle of which is a longitudinal board for paddlers; there is a Moluccan attachment, but he does not give his authority, nor the date of the craft.

Friederici noted that the Halmaheran attachment greatly predominated in the north of Halmahera at Tobelo and Galela, though occasionally the U-Moluccan attachment occurs. In Halmahera the small ledges on the inner side of the hull of the canoe are not eyed, but cross-bars are placed beneath them atbwart the hull, and the booms are lashed to the cross-bars by arenga or by coconut-fibre string. The two lateral feet of the triangle-mast have their bases perforated, through these holes is passed a transverse rod which itself passes through and is supported by two short stanchions which are lashed to a cross-bar; but in Tobelo and Galela the stems of spikes bent at a right angle are fastened to cross-bars, and the inwardly projecting spike is inserted into the hole in the feet of the two masts. Forrest (pp. 9, 18) was the first to draw attention to the merits of the very practical tripod mast. The upper ends of three bamboo poles of this very light mast are fastened close together hinge-wise in such a way that only one pole projects beyond the others, and to this is attached the mast rope. Below, the middle foot is the longest and it can be tilted at any angle as occasion demands (Fr., II, p. 240). A short central wash-strake is added to some outrigger canoes, with two notches on its free border in which the booms rest. The floats at Tobelo, Galela, and Kau are fashioned out of bamboo poles slightly bent up in front, or of thin wooden rods shaped like the runners of a sledge. The forks on which the mast, sail, and other gear are laid may be made of a natural branch, a carved piece of wood, or of a branched stick inserted into the hollow of a piece of bamboo; these are strongly lashed to the booms. Paddles, as everywhere else in the Moluccas, have a crutch grip. Balers at Halmahera and Ternate consist of a bucket-shaped little basket made out of a licuala leaf or are cut out of a piece of bamboo. Wooden anchors weighted with stones are used universally in Tobelo and Galela, as iron has not come into use there (loc. cit., p. 241). As a matter of fact, similar anchors are widely employed in Indonesia.

In Weda Bay, Patani, and Buli, canoes have two booms with a Halmaheran attachment, but in some a false-boom is added; in this case the inner longitudinal spar (which lies beneath the knee-bend of the attachments) merely extends from one outrigger boom to the other, whereas the outer longitudinal spar projects much further beyond the booms, and its ends are bound tightly with arenga or ratan lashing to the ends of the float, while a third lashing passes from the crossing of the falseboom and outer longitudinal spar to the middle of the float. In Weda Bay and Patani the floats are usually of bamboo, bent upwards rather high, in Buli the sledgerunner type is prevalent. Friederici did not notice the forked mast and gear holders 
in Weda Bay and Patani, which, however, occur at Buli. Neither did he see a plank (or wash-strake) added to the hull, as in the north of Halmahera, but, sporadically, the edges of the dug-outs were heightened amidships by the addition of strips of gabbagabba. The attap cabin in the middle of the craft had closed sides, these are left open further east. The tripod-mast is present. The triton-shell trumpet is used. A simple, often rough, dug-out without outriggers occurs (loc. cit., p. 242).

A shorter, more obtuse form of Halmaheran attachment is found at Ake-Sĕlăkă (Fig. $16 \mathrm{C}$ ), and here and there the U-Moluccan attachment. The floats are mostly of the sledge-runner type, but the bamboo form with a slightly upward curve in front also occurs. When mast and gear forks occur, they are mostly crescentic. The rectangular sail, as usual, is set obliquely. Everything else is as in other places in Halmahera (loc. cit., p. 243).

Friederici points out that the peoples of Halmahera and neighbouring islands form a separate linguistic group, remote from the Malayo-Polynesian languages and apparently unconnected with any hitherto known Papuan languages. Ethnologically the Alfurs of Halmahera form a great group with the Alfurs of the Moluccas and those of North-east Celebes, and in the main probably anthropologically as well. He could not see that the natives of Tidor, Ternate, and Halmahera differed appreciably in appearance from other Indonesians, and in none of the places that he visited did he note features or skin-colour approaching those of the so-called "Aryan race" (III, pp. 9, 10).

"There are at least five dialects among the Alfurs of Minahassa. The more westerly and southern languages of Celebes (those of Gorontalo, Baree, and the Togian Islands) are further removed from Melanesian languages. The dialects of the Alfurs of Minahassa and of the Sangir and Talaut Islands belong to the great group of Philippine languages, which, according to Kern, reach to Formosa. But the bahasa tanah and the dialects of Minahassa have a common linguistic substratum, so that originally the Alfurs of Ceram and its neighbourhood were akin to those of Minahassa" (Fr., III, pp. 10, 11).

\section{Celebes and Neighbouring Islands.}

The aboriginal inhabitants of the Sulla Islands belong ethnologically to Middle Celebes ; the coastal folk are a very mixed crowd (Fr., III, p. 9). There is a Halmaheran attachment.

Friederici saw three kinds of craft in Buton: (1) a boat without outrigger, (2) boats with a double outrigger with two kinds of attachment $(a)$ with usually three booms, the U-Moluccan attachment and three bamboos bound together to form the float, (b) an attachment which recalls the Halmaheran (Fig. 16, A). In Makassar he saw no outrigger boats, lepălep̌̆, but according to models in the museum at Weltevreden double outriggers occur. In Bugi also the lepălepă is found (Matthes, Boegi, p. 544, quoted by Fr., II, p. 235). 
In Celebes a direct lashed attachment has been recorded at Makassar and Gowa, a model from the latter place with five booms and a mixed direct attachment is referred to on pp. 80, 84, 106, 114 ; it is found on the Malili River (at the north-east of the Gulf of Boni, on Matanna Lake, further inland, at Paloppo (on the west side of the head of the Gulf of Boni and at Libukang in the same gulf, where the Sarasins illustrate one canoe with a float composed of four bamboos; it also recurs at Kema in the extreme north-east of the island. The Halmaheran attachment, however, in various forms, predominates throughout Celebes. According to the illustrations of D'Urville (II, pl. XXV, 3) and Pflüger (pp. 100, 103) the canoes on Lake Tondano, Minahassa, are simple dug-outs with square boarded ends. The " praus in roadstead of Makassar" figured by Pflüger (p. 71) have a triangle mast, the yard may be lowered to the boom or the boom raised to the yard. The Celeban canoes almost invariably have two outrigger booms, the model from Gowa just mentioned being very exceptional and probably represents a Sulu craft and not a local one. The outlayers of sailing boats in the Gulf of Boni are referred to on p. 76.

The region embracing Minahassa, Banka, the Talaut (including Sangir), and Tulur groups is characterised by the occurrence of a mixed direct lashed and Halmaheran attachment : this may, for short, be termed the "north-eastern Celeban area." The examples known to me are described on pp. 95, 96. Müller, as we have seen (p. 98), draws attention to the affinities of the mixed attachment in this area with that of the " eastern Javanese area" ; in both the fore boom is lashed directly to the float, but in the Javan area the indirect attachment of the aft boom is inserted into the float, whereas in the Celeban area it is lashed to it, being a typical Halnaheran attachment. There is, however, at Kema in Minahassa a mixed rod and Halmaheran attachment in which the fore boom has a rod attachment which apparently is inserted into the float, while the aft boom has a typical Halmaheran attachment (Fig. 23). There was much going to and fro in Indonesia in former times, so no surprise need be felt if these two regions, separated by the whole length of the large island of Celebes, show some resemblances, but these are not close in detail.

A direct lashed attachment occurs at Sangir and a mixed lashed direct and straight vertical Halmaheran attachment. More than two booms are present. Miniature sakit canoes from Nanusa Island (to the north-east of Celebes) have two or three booms which are simply pegged on to the float ; the mode of attachment has no significance, as these are merely ceremonial models ; some sakit canoes are without outriggers, they are employed in the exorcism of the sakit or spirit of sickness (pp. 77, 96, and Hickson, 1893, Fig., p. 290).

\section{Sulu Archipelago.}

In the Sulu archipelago small canoes may have but two booms and the outrigger may be placed at the aft end of the canoe (Guillemard, 1889, p. 206 ; G., Nos. 180, 217). Usually there are three or four booms (p. 80). In these canoes the fore and aft booms are always straight, whereas the central booms are downwardly curved at 
their ends (Fig. 7), but in Wilkes' figure (V, p. 333) all three booms are downwardly curved-this is probably incorrect. In all cases there is a direct lashed attachment. Two or more upwardly curved bars are generally fastened transversely across the canoe, usually they are attached to the booms (when they may be called "boomspars," they are the "Bügel " of Müller) and frequently they bear, near each end of the boom, a crutch or forked stick to support gear; in the canoe figured by Wilkes each of the three booms supports a semicircular spar with forked ends, the arms of which in the sectional view (V, p. 332) are shown as connected with the boom by a lashing.

An analogous combination of straight and partially curved booms is found in the Madura district, where the straight booms are tied to, and the curved ones inserted into, the float (p. 84). In a model from South Celebes, the fore and aft straight booms are inserted into the float, while the middle three are lashed to it (p. 113). It is possible that the latter may throw some light on the somewhat perplexing difference in form of the Sulu booms, and one is tempted to suggest that the outer straight Sulu booms were originally inserted into the float, but this would be the exact opposite to the arrangement at Madura:

Probably belonging to this region is the "pirate craft" of Pritchett, which has three strongly curved outrigger-booms on each side, the forked ends of which are lashed to the floats (pp. 81, 84). Guillemard states that the southern part of Sulu Island " is inhabited chiefly by the Bajaus or sea-gipsies, a people quite distinct from the Sulus, and of a much lower type" (1894, II, p. 90).

\section{Philippines.}

Müller (p. 244) says that the canoes of Sulu, Zamboanga, and Cebu are in the main similar. The floats are not attached to the "Bügel" (Fig. 2, A-C) but are attached directly to the booms [by a lashed attachment], which are not more than two in number and are unusually thin and fragile, and need strengthening by the elasticity of the concave "Bügel "[" boom-spars "] which are half the length of the booms. Vojnich figures three booms at Manila and on Lake Lanao in Mindanao (pp. 378, 383).

Mr. Henry Balfour has very kindly made drawings for me (Figs. 30,31) of one of two similar models of canoes used on the Pasig River, Manila; the specimens were collected by the late Admiral Maclear and presented by Mrs. Maclear to the PittRivers Museum, Oxford. They are fitted with a double outrigger which, however, is provided with but one boom which is lashed to the float, the other end of the float is lashed to a thwart which projects slightly beyond the sides of the hull, an arrangement which, so far as I am aware, is unique. The models are furnished with an awning.

The outlayers of Philippine boats have been noted on p. 76, and the remark made by Folkard raises the question as to whether the structures of the Oxford models may not really be outlayers.

Judging from an illustration given by A. H. Savage Landor, a canoe with a double outrigger, two booms, and a direct lashed attachment occurs in the Cagayan Group, Mindoro Sea (I, p. 228). 
The most widely spread, important, and hest known languages of the southern Philippines is that of the so-called "pirate tribes" of Mindanao and Sulu. It is a dialect or form of Bisaya with a strong infiltration of Malayan elements, and is spoken by the Moros of Mindanao, Basilan, in the Sulu and Tawi-Tawi Archipelagoes, Palawan, Balabec, and in North Borneo (Fr., III, p. 11).

\section{Borneo.}

As outrigger canoes are such a feature in Indonesia, their almost total absence from Borneo is rather surprising, but this absence, as in the western and northern

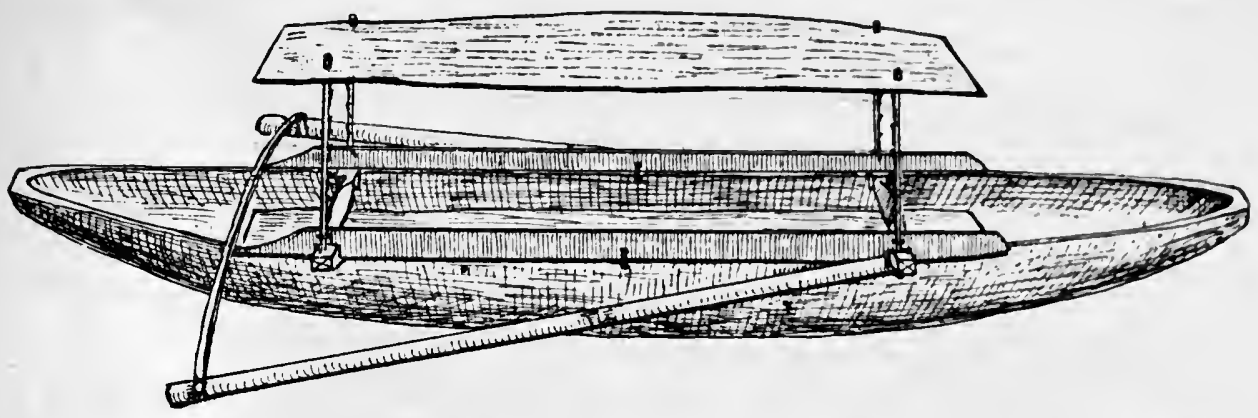

HiG. 30.-MODEL OF A CANOE WITH A DOUBLE OUTRIgGer AND ONE BOOM, PASIG RIVER, MANila (SKETCH BY H. BALFOUR, OXFORD).

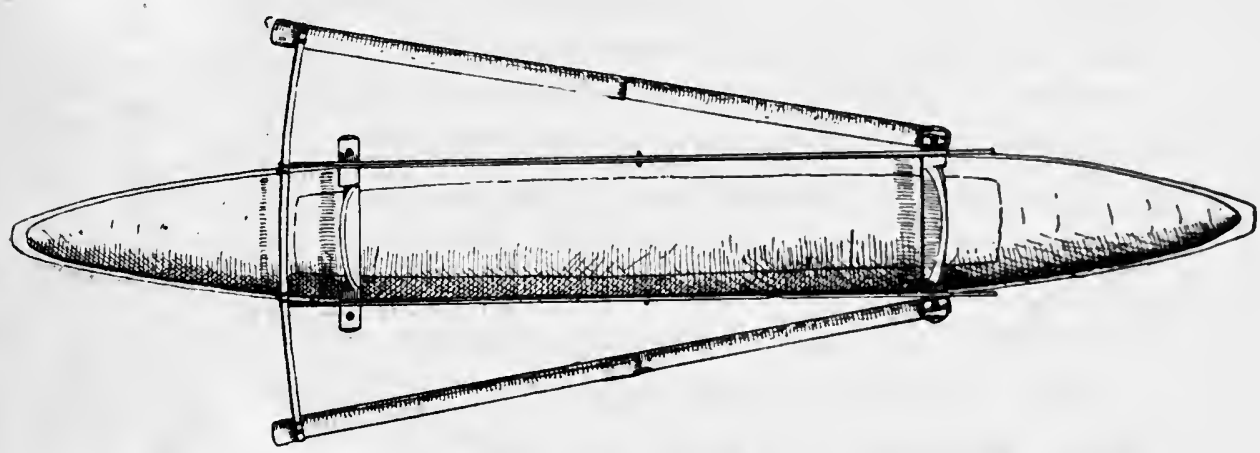

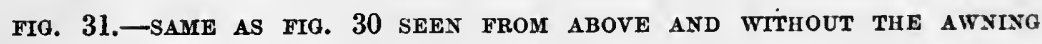
(SKETCH BY H. BALFOUR, OXFORD).

portions of both Sumatra and Java, seems to be due to secondary causes. Hose and McDougall give an illustration (copied from Ling Roth, I, p. 144) of a rough model made of pith of a small canoe with two outriggers, the booms of which pass through the solid hull and are inserted laterally into the floats. The model, which is in the Leiden Museum, came from South-east Borneo, a district far removed from the Malanau country. Apparently a similar imitation canoe, jong, is employed by the Malanau in the bayoh ceremony for the casting out of diseases (II, Fig. 84, p. 133). 
They state that the Malanau are Klemantans, a mixed group of Bornean peoples, of the coast regions of Sarawak, most of whom have recently become converted to Islam, while all of them have been much influenced by Malays (II, p. 129). A. E. Lawrence; of Sarawak, kindly gave me two sketches (Fig. 32), drawn from memory, of toy "schooners," jong, sailed by Malanau and Malay children along the Sarawak coast, both have a single outrigger, one with two straight booms, while the other has only a single boom ; in both cases the booms are inserted into holes in the side of the float, pelempong. I am also indebted to Ivor H. Evans, of Perak, for informing me that when travelling in the Tempassuk District of British North Borneo, some Bajaus temporarily fitted a small low dug-out, gobang, for him with a double outrigger of two straight booms which were lashed to bamboo floats. This was the only occasion

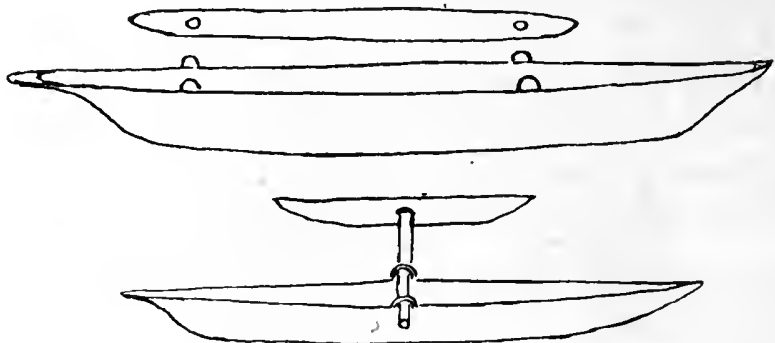

FIG. 32.-TOY CANOES, jong, OF MALANAU AND MALAY CHILDREN, SARAWAK (FROM SKETCHES BY' A. E. LAWRENCE).

on which he had seen an outrigger in Borneo, but he had not very much to do with the villages near the coast. He adds, "The Bajaus were great pirates in the old days and might have picked up the idea in any of the islands further east." The word gobang is the Sulu guban (infra), thus the canoe and its name may be an importation, or may be indigenous to the area as a whole. The outlayers described by Beeckman have been noted on p. 76. For a description of the usual type of craft in Borneo see Ling Roth (II, pp. 246-254), and for ceremonial boats (I, pp. 144, 283); he states, "It would seem at one time Sumatra was supplied with boats from Borneo" (II, f.n., p. 249) ; also Hose and McDougall (I, pp. 55, 56, 132, 166), Gomes (pp. 49-51) and Nieuenhuis.

\section{Notes on the Native Names for Canoes and Outriggers.}

The following terms for outrigger canoes are given by Friederici, the names for boats without outriggers are placed within ( ). Terms of outrigger canoes added by me are placed within [ ].

Andamans [châ-rigma]. Nicobars [due, daë and doai]. Mentawei [abak]. Engano [eloha]. Sumatra [jellore, ballelang]. Bali, dyukŭn, sămpăn in Malay. Confined to a restricted area of the Lesser Sunda Islands, we find in Sumba, tena, teneh; Middle and Eastern Flores: Sikka, tena, and Maumeri, tenah; Solor, tenna. 
Flores, korakora. The most customary names for an outrigger canoe in Banda, Amboina and the Uliassers are prâu (prahř) and hăkŭ; but also tala, talalo, talo, alal, sapu and sapou are to be found in the country speech of Ambon and the Uliassers (II, 237). Sumbawa, lopie or lopi. Banda, korakora, prau (kolekole, but called prau when outrigger added; orembai). Amboina, prau, prahŭ semăn, prahu belan, hakŭ, kolekole, korakora, lepa or prahŭ lepalepa, tala, talalo, alal, sapu (orembai). Batjan, nyŏn. Ternate, oti or oti. Halmahera: korakora; Weda Bay and Patani, yël; Buli, pělăn; Tobelo, ngoť̌r̆, ŏtıli or otil, (here the lepălepă is a dug-ont without outrigger); Galela, deru; Ake Selaka, oti. Celebes, lepălepü, korakora ; Salaier, lopi. Sulu, guban.

The following notes are taken mainly from Friederici (II, pp. 244-246), who gives full references. He also gives the variants of these terms that occur in Melanesia, but these do not concern us here.

The dyukŭn of Bali does not occur in any form eastwards of the Philippines. It is the Malay djokong; Javanese djukung, djungkung; [Nicobar, duēe]; Batjan, nyon ; in the Philippines: Tontemboan, rungku, Bisaya and Bicol, adyong; Iloko, daon; Tagal, dau'ong; [Borneo, jong]; Diadōku or diadǔku is the name for the outrigger-booms at Tobelo (Halmahera). Also cf. ionco (p. 106).

Kŏlěkŏle is clearly the same word as kŏrŭkŏrŭ, which term is current in Makassar, throughout the Moluccas, in Halmahera and Western New Guinea, and it also extends to Flores. It is more than doubtful, says Friederici (III, p. 159), whether the word korakora of the Moluccas really goes back to the Arabic qorqôr and thence to the Portuguese carraca. Valentijn, who treats the word as an indigenous one, is certainly wrong when he derives it from the Malay kura-kura. In the oldest Portuguese and Spanish accounts of the Moluccas we find caracora, coracora, carcoa, but never carraca; de Morga not only says expressly that it is an ancient and indigenous word among the Tagals of Mindoro, Marinduque, and Luzon, but that it is also a true MalayoPolynesian word: in the Malay Peninsula, kolek (a small fishing boat); Amboina, kolekole; Mota (Banks Islands) kora ; San Cristoval (South Solomons), ora. Friederici asserts that this equation is not merely accidental as there is other support for it, and he has shown that most of the boat-names of Eastern Indonesia recur in Melanesia. He adds (III, p. 159) that the Moluccan korakora corresponds to the Philippine baranguay. [The Achinese have a sailing boat called "kolay" (Folkard, p. 481)].

The Malay prahu, perahu, p.rahu, prau, etc., is a general term for canoe, boat, or ship and appears to be used indiscriminately in places for craft with or without an outrigger, and therefore has no special significance, thus in Amboina an outrigger canoe may be termed prahŭ semăn.

The hăkă of Amboina is the Malayo-Polynesian wangka, which is so widely spread in the South Seas as to be universal. In Saonek and Sorong, wā̃, and Manukwari (Doreh) wa or wai : all in New Guinea. [Ray points out that the term laka, 
used in Madagascar for the canoe with a double outrigger, " is no doubt the Melanesian waka, etc., also that Malagasy and Tagal are more closely related than either of them is to the language of the islands between" (Haddon, 1918, p. 53). Christian (p. 229) gives: Malay wangkang, a junk; Moluccas, waga, a vessel ; Philippine Islands, banka, a canoe ; Waigiu, waag, a pirate craft. Keane points out that the Mentawei $a b a k$ is the $v a^{\prime} a$ or vaka of Polynesia $(1899, f . n . ;$ p. $244 ; 1920$ f.n., p. 235).]

Another interesting word from the point of view of migrations to the Western Pacific is the lepălepra of the Bugi [originally a people of the Boni district of Celebes], it is also employed at Makassar ; variants are : Malay Peninsula, lopeh, lupek, lopek; at Bima and Sangar in Sumbawa, lopie or lopi; Salaier Islands, lopi; Amboina, lepa, prahu lepalepa; Tobelo (Halmahera), lepălepă, for a dug-out without an outrigger (Fr., II, p. 241) ; Philippines, lapis, lapes.

In Ambon and the Uliassers are alal, tala, talo, talal, talalo; it is possible that the word yĕl, which is apparently confined to Weda Bay (Halmahera), belongs here.

In Halmahera and the neighbouring islands we find: $\not t i$ or ōti, Ternate, Roni, Ake-Selaka ; oti, Tidor Isam, Tololiku, Waioli ; ngoǒtili, Madole, Tabaru ; nŏtili, Ibu ; ngŏtřrĭ, otili and otil Tobelo.

Apparently restricted to Galela and Loda is the word deru.

Obviously connected with pělăn of Buli in Halmahera are : bero, Solor ; belo, berok, prahu berok, Timor; bero, Wetta and Tenimber; prahŭ belăn or belang; Amboina ; beri-beri Namatote Island, north-west of Triton Bay, New Guinea ; in the Philippines: balanay, Tagal ; baranay, Iloko. Kern equates the velo-velo of Fiji [which belongs to this series] with Biduq, Malay and biluq Tagal (Fr., II, p: 245).

Friederici also groups together loju, Sulla Islands ; lotu, Gesir, south-east point of Ceram ; lete'ie, lettej, Aru Islands.

With the term guban of the Sulu Islands may be equated kowa, Sava (between Sumba and Timor); ofa, ofak, Rotti (south of Timor); gobun, Bongu. Later Friederici (III, p. 160, f.n., 280) adds that the guban of the Sulu Islands occurs as goba in Malay, and it appears to him that the Dayak top, a small ship, is also a related word; [among the Bajau of British North Borneo we find gobang, p. 116].

The beautiful, large plank-boats without outriggers of Ambon and Banda come from the Kei Islands, but their name of orěmbā̌̆ or ŏrĕmbai, also đrănbā̆ or ŏrŭnbaik, does not come thence but is probably of Malay origin, rěmbaja; other variants in the country-speech of Amboina are : arobail, arubai, arubaillo, arumbai, and as arumbae in Gesir (Fr., II, pp. 235, 236). An orembai with outriggers is called korakora, a word which is found as kolekole, kolek in Malayo-Polynesian languages (Fr., III, p. 159). Martin (p. 86) says that the name orembai is a contraction for orang baik "good friend " (or "servant") and comes from the era of the Hongi voyages!

The number of the terms for booms given by Friederici is insufficient to enable us to arrive at any conclusions. The Moluccan term seems to be the üramŏn or ŏramŭn of Banda, which becomes bairŭnŭn in Batjan and brăyŭnăn in Bali. Several terms 
are employed in Halmahera, one of which the nüdyu-nŭdyu of Ake Selaka extends as might be expected to Ternate and reaches Amboina, where nadyŭn also occurs. Concerning the terms ěri, ŭri of Buli and seš̆ of Galela (both in Halmahera) there is nothing to say, but as Friederici points out, the diadskǔ of Tobelo seems to be the origin of the word kiato, which is so widely distributed in Melanesia and Polynesia for an outrigger boom. [The Nicobar name is deia due.]

Friederici gives the following names for outrigger attachments: Bali, š́døk ; Banda, ǔngerŭ ; Amboina, păgupăgu ; Batjan, tudŭtudă ; Ternate, pagu; Halmahera : Buli, ť̌té, Tobelo, tă̌ntene, Ake Selaka, š̌ǩr. [The number of names available is so limited as to be inconclusive. The sedek of Bali may be connected with the seke of Ake Selaka, and Ternate and Amboina are again linked together. The Nicobar term is heneme.]

As Friederici points out (II, pp. 246, 235-243), the term sŭmün, or some variant of it for the float of an outrigger, is so widespread among the Malayo-Polynesian peoples that the investigator should note whenever it does not occur; it is its variants that need comparison. Thus we have : Banda and Ambon, semin ; Batjan, somin ; Ternate, sam̌̆; Halmahera: Weda Bay (and Patani) zomŭn, somrn; Tobelo,

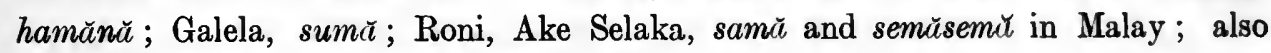
variants as in Sangir, sahemmang.

He thinks, contrary to Kern, that the general term for outrigger-float is derived from the old Javanese sama, "like," Bali, sama samasama; also Sumba, sama means " at the same time, together, with, at the same time like," etc. "For the float is in reality a miniature boat, a small counterpart of a boat, indeed it has been stated, from an ethnological point of view, that the outrigger boat has been derived from the double-boat. So also have we in Malay : sama, "resembling, similar"; samasama, " together," and in Tagal, sama, " companion, to accompany " and " companion like the servant"; samaco, "a fitted-up boat" and "to prepare or embellish, to construct la banca (the Philippine canoe)."

The only other terms Friederici notes for float are the bŭră of Buli, concerning which he has nothing to say, and the kăter or kătir of Bali, which is quite obviously : Tara (Bareë) katigi; Bisaya, katig; Lake Magindanao, Mindanao, katik; and Bikol, katig. This appears very significant when we recall the correspondence between certain craft of Bali and those of the area between the Philippines and North Celebes. [The Nicobar name is hentaha.]

\section{General Conclusions.}

It may be taken as a general principle in distributions, whether of animals or men, that the more primitive, that is to say less advanced, types are generally to be found on the margins of an area or in the less accessible or undesirable localities within the area. If the area be an archipelago like Indonesia we should therefore expect to find more primitive conditions on its outskirts or in the interior 
of the larger islands, and many travellers tell us that as a rule the latter is indeed the case.

As a knowledge of the ethnography of Indonesia is necessary for a study of that of Oceania, so the converse is equally true. Cultures have been so crowded into Indonesia at various times, and so many internal movements have taken place, that a disentangling of the chronological sequence of the cultures is a very difficult undertaking. A valuable attempt of this kind has been made by Perry (1918), which, however, has little bearing on the present problem. It is recognised that migrations of variable extent take place everywhere, each always associated with definite and characteristic cultural elements. We know that similar migrations from Indonesia have taken place at intervals to various regions of the Pacific which transported samples of the then stages of culture. It is from a consideration of such samples in these Oceanic areas and a co-ordination of the linked cultural elements they contain, that the relative age of ethnographical data in Indonesia will ultimately be elucidated. From different points of view Graebner, Friederici, and Rivers have done great service in this direction. Graebner $(1905,1909)$ was, I believe, the first to utilise the general type of canoe, as well as the presence or absence of outriggers and most obvious features of their attachments, as evidence for the differentiation of various cultures and culture-strata in Oceania, but the details he gives are very meagre. Friederici (II, 1908) has presented a mass of technological and linguistic evidence concerning canoes, which is of the greatest importance for the study of these problems, and later (III, 1913) has attempted to map out certain cultural streams from Indonesia into the Pacific. Finally, Rivers (1914) has utilised similar evidence in his dissection of the cultural strata in Melanesia.

All movements between different islands in Indonesia and those thence to Oceania must have been accomplished by boats of some description or other, and eventually we may hope to discover what kinds of boats they employed, the types of outriggers and varieties of attachments. My main object in this paper is to prepare the way for more extended historical studies on these lines. .

The problems of the distribution and history of canoes in Oceania are beyond the scope of this paper; for this purpose it will be necessary to make a more thorough analysis of the types of canoes and outriggers throughout the Pacific, there being many varieties which have to be accounted for, and, furthermore, a definite terminology will have to be generally adopted. But for my immediate purpose I find it necessary to make a few remarks upon certain distributions of canoes in Oceania.

A very brief summary of the probable racial history of the area will perhaps not be out of place. There seems sufficient evidence to assume that much later than the original occupation of a part or the whole of Indonesia by Negritos, Papuans, and the less early Pre-Dravidians, were the migrations from somewhere in Southern Asia of the dolichocephalic Indonesians. Possibly some of them were, at all events in their later migrations, already somewhat admixed with southern Mongoloids. 
Somewhat later perhaps came swarms of brachycephalic southern Mongoloids, who may conveniently be termed Proto-Malays, some of whom may have been crossed previously with other stocks. On the whole they have dominated the true Indonesian peoples; but the bulk of the population of the archipelago consists of various blends of these two stocks. The Malay Peninsula was first occupied in the twelfth century A.D. by the true Malays, Orang Malayu, who crossed over from Menangkabau in Sumatra ; thence at the close of the thirteenth century they spread over the East Indian archipelago. But long previously to this other peoples had secured a foothold in Java and elsewhere. From the first century of our era there were migrations from India. The Javanese Babads tell of an Indian prince who came to Java about A.D. 78 or 120 , where he found a nomadic people. We know of Indian colonies in Bali, Sumatra and Java in the third century (Fritsch, pp. 14, 21). I have already referred to a later colonisation (p. 100).

Chinese infiltration may not have begun after 220 B.c., when South China was conquered from the aboriginal population and a seaboard acquired, but commercial relations existed with Java and other islands in the fifth century A.D., and were continued for a long period, perhaps they have never ceased. The Chinese Buddhist missionary Fa-Hien, or Hsien, visited Java from India in the fifth century A.D.

Arabian traders voyaged to the East Indian archipelago long before the time of Muhammad, but Islam changed the Arab trader into a teacher of the new doctrine.

At the beginning of the sixteenth century the Portuguese made settlements, and were followed later by other European peoples (Haddon, 1911, p. 35).

Two hypotheses are current concerning the origin of the outrigger : (1) That it is derived from a double canoe, one of the canoes having degenerated into the float of the outrigger. In double canoes one of them often is smaller than the other and in some places the smaller canoe bears the same name as the float, as for example at Mailu, in British New Guinea, where the term larima is used for the smaller element of a double canoe, orō $\bar{u}$, and for the float of a single canoe, vaona. (2) That the canoe was evolved from the central log of a float or raft, the two outermost logs of which have persisted as the floats of a double outrigger, an evolution which took place solely in Indonesia. If the first hypothesis be correct, it would follow that the single outrigger was the primitive type, but the second hypothesis would make the double outrigger the original form. But if we assume a dug-out to be the initial boat, and it is or has been used in practically every part of the world (rafts, bark canoes, and skin boats are another story), there does not seem to be any reason why either form of outrigger should be the earlier, though in this case there is no structure from which an outrigger could be naturally developed.

The question of the priority of the single or double outrigger is of some importance. So far as historical data go, the earliest record we have is that of the Indo-Javanese double outrigger ships of twelve centuries ago. Apart from the East African area, to which I have already alluded (p. 78), double outriggers outside of 
Indonesia are found with a rare and scattered distribution in Oceania. They occur in the area which includes Torres Straits and the estuary of the Fly River, but single outriggers also now occur there, both being associated with an overcrossed stick attachment (p. 85). They are also to be found in North Queensland, (a) the Batavia River type with an attachment of two vertical sticks, from Batavia River in the Gulf of Carpentaria, round Cape York to about Cape Grenville (lat. $12^{\circ} \mathrm{S}$. ) ; (b) the Claremont type with a direct lashed attachment, apparently from Cape Direction (lat. $13^{\circ} \mathrm{S}$.) to Claremont Point (lat. $14^{\circ} \mathrm{S}$.) (Haddon, 1913). They have been reported in Oceania, formerly in the Pelew Islands, and doubtfully in the Seniavina Group of the Carolines ; they occur at Nissan with a direct lashed attachment, temporarily in the Solomons with three booms lashed to a float consisting of a bundle of bamboos, doubtfully at Samoa, and formerly at the Marquesas, and also formerly at Easter Island with a direct lashed attachment (Haddon, 1913, p. 621). A scattered marginal distribution of this kind suggests antiquity, and provisionally we may accept this supposition. Although the Torres Straits area is not geographically remote from Indonesia, I am strongly of opinion that it is culturally remote and that the double outrigger came there by the West Pacific route.

In Torres Straits and the estuary of the Fly we have definite evidence that the single outrigger is ousting the double, and it seems probable that this has occurred elsewhere, though there is very little precise information on the subject. Müller (1912, p. 245) alludes to a change of double outrigger into a single as having occurred in the Pelew Islands. In a letter to me dated July 14, 1913, Friederici says: "I have now no doubt that the kŏp [the Nissan double outrigger canoe with a direct tied attachment] has been brought by a Philippine or sub-Philippine wandering stream to New Ireland and neighbourhood, and that the double outrigger has in course of time been displaced by the Melanesian single outrigger and has stood its ground only in the island of Nissan." Apparently both forms occurred at Easter Island (p. 124).

The double outrigger is more stable but clumsier than the single, the latter has better sailing qualities, but great care has to be exercised in the management of the float in order to maintain the balance of the boat.

The single outrigger is a marginal phenomenon. Within Indonesia it occurs very rarely and sporadically (p..78). It is normal in the Andamans and Nicobars and reappears in Geelvink Bay, it is practically universal in New Guinea and Oceania.

Very frequently associated with a single outrigger is the presence of several booms as in the Andamans, Geelvink Bay, the Massim, West Papuo-Melanesian, and Gulf districts of British New Guinea, and most parts of Melanesia, but to a much less extent in Polynesia. On the other hand, we have seen (p. 80) that the Philippine area, including the Sulu Islands, Sangir Islands (occasionally), in Misol, Waigiu and other neighbouring islands, and Geelvink Bay numerous booms are associated with a 
double outrigger. Thus so far as Indonesia is concerned several booms to a single outrigger is a marginal characteristic, and so is, but to a less extent, the association of several booms with double outriggers, as this is practically confined to the eastern margin of Indonesia. We must not, however, overlook the occasional occurrence of three booms within the central area of Indonesia (p. 80). At present I leave it an open question whether these are relics of a more general distribution, as I suspect them to be, or as borrowings from the eastern margin.

Indonesia, excluding its eastern margin, is therefore characterised by canoes having double outriggers with two booms.

The diffusion of canoes with double outriggers and two booms trom Indonesia into Oceania must have taken place in very early times and possibly on two occasions, one with a direct tied attachment (p. 124) and the other with an inserted stick attachment. At present I am not in a position to suggest which is the older type; but if the float be derived from the smaller element of a double canoe an indirect attachment would not become necessary until the float had been reduced to a log or a piece of bamboo. On the hypothesis of the evolution of the outrigger canoe from a raft; the tied attachment would be the more primitive, as the need of an indirect attachment would not arise until the central plank of the raft had become converted into a canoe. On the other hand, a stick attachment appears to be characteristic of various types of primitive outrigger canoes.

I now pass to a consideration of the distribution of the main types of attachments.

\section{A.-Direct.}

1. Inserted.-With the exception of the somewhat aberrant Balinese attachment I have not come across an unequivocal case in Indonesia of an actual canoe where all the booms are so attached.

The direct inserted attachment has a less extended range than the lashed. The only Melanesian record is from Eromanga in the New Hebrides (Hedley, p. 287). Krämer found at Tutuila in the Samoan group that the straight booms have a downwardly slanting branch the end of which is inserted into the float (1903, II, p. 249 ; 1906, Fig. 42, p. $415 ; 1911$, p. 23a). I have been told it occurs at Rotuma ; Friederici also records it for Mangaia and Rimatara, while in the more northerly Cook Islands of Atiu and Mitiaro the end of the booms is curved downwardly to be inserted in the float (Fr., II, p. 314, Figs. 127-130). The direct inserted attachment also occurs in the Paumotus (Pallander, p. 194, figures a canoe with two booms, the fore with a crooked inserted boom, the aft with a stick attachment). It thus appears to be most prevalent in the Southern Polynesian area.

I feel some slight hesitation in accepting all these records, as the Tutuila attachment is very like that which occurs at Funafuti, which, though it looks as if it should belong to this class, is really a lashed attachment, and we know there have been close relations between the Samoans and Ellice Islanders. 
2. Lashed.-This type is very widely but sparsely distributed throughout Indonesia, so much so that little can be deduced therefrom, unless it signifies that it is really an ancient form. It is interesting to note that it crops up in various lakes and rivers, where its appearance may mean that it is an old type, or simply that in these calmer waters it suffices for the needs of the fisher folk. But it is also significant that this type is very prevalent in the Sulu Islands and in the southern and central Philippines, i.e., in the eastern margin of our area.

The direct lashed attachment (with a single outrigger) alone occurs in south India and Ceylon, whence it may have spread into Indonesia, or may equally well have traversed in the reverse direction.

It very rarely crops up in Western Oceania, where it is associated with a double outrigger ; e.g., the kŏp of Nissan in the North Solomons (Krause (Fig. 101) ; Friederici, cf. Haddon 1913, Fig. 14) and North-east Queensland from $13^{\circ}-14^{\circ} \mathrm{S}$. lat. (Claremont type, loc. cit., Fig. 7, after Roth). It occurs with a single outrigger at Nonuti in the Gilberts (Fig. 29) and universally in the Hawaiian Islands, and in the Marquesas (model, Salem Museum ; ? Pallander, Pl., p. 240); at Easter Island with a double outrigger (Choris, Pl. X, Fig. 1, cf. Haddon, 1913, p. 621); but in the "Atlas du Voyage de la Pérouse" (London, 1798, pl. 61), a single outrigger of two booms is shown, the float rests upon and is tied to the booms ; ? Napuka (Wytookee), Paumotus (Wilkes, I, p. 319, but the sketch is not convincing); Tahiti (Wilkes, II, p. 21 ; Edge-Partington, Ethnol. Album, I, Pl. 29) ; and Huaheine, the easternmost of the Leeward Group of the Society Islands (Ellis, II, 1831, p. 352). At Funafuti in the Ellice Islands (Fig. 33) there are three straight booms
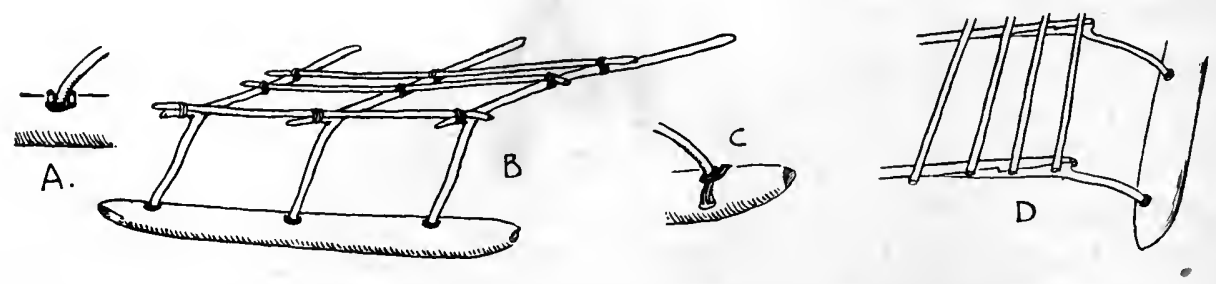

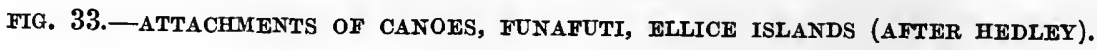

which have a long oblique branch near the end, the tip of this branch rests on the float to which it is lashed, sometimes it is lashed to short pegs on both sides of the boom (Hedley, p. 286, Pl. XV, Figs. 1, 6, 7; Alexander, p. 796, pl. 35); in a model in the Cambridge Museum there is only one peg; the pegs are inserted into the float. De Clercq and Schmeltz describe (p. 94) and figure (Pl. XXIV, Fig. 5) a canoe from Ansus, New Guinea, with a direct lashed attachment, but as all the accounts we have from Geelvink Bay speak solely of a "spike" attachment we may suspect that the model is inaccurate. In $1914 \mathrm{I}$ saw at Buniki, a short distance 
up the Dabara arumo, a small river on the east side of the Bebea River (the northerly mouth of the Bamu) in the Western Division of British New Guinea, a solitary example of a canoe with a single outrigger of two booms with a direct tied attachment-it may have been an individual occurrence of no special significance, as the canoe was a very small one-another canoe had the stick attachment characteristic of that district.

A mixed direct inserted and stick attachment.-In all the boats seen by Friederici at Tahiti and the North and South Tuamotus (Paumotus) the aft boom had a direct inserted attachment, but the fore boom had sticks (Fr., II, p. 314, Figs. 131, 132) ; Pallander (Pl., p. 194) figures a canoe at Anaa, Paumotus, in which the angular (? fore) boom is inserted into the float and the straight (? aft) boom is supported by two pairs of undercrossed sticks.

\section{B.-Indirect Attachment.}

(a) Attachment Inserted into the Float.

1. Stick.-The only places in Indonesia where this occurs are the Andamans and Nicobars, i.e., marginal within the area ; here the sticks vary in number and arrangement, they may be vertical, oblique or if in pairs overcrossed or undercrossed.

In a copy of an old engraving (Mager, p. 137) two double booms, one above the other (boom and boom spar), are attached to the float by two sticks on the same side of both booms in a canoe of the Mariana or Ladrone Islands; Anson gives a most excellent account and engraving (reproduced by Ling Roth, p. 123, Pl., p. 118, and sketched by Folkard, Fig. p. 463) of " a flying proa taken at the Ladrone Islands," it has three booms (the central one may or may not be a false boom) with the same attachment, there are two longitudinal spars and two oblique stay spars; and Safford (Pl. XI, p. 493) gives a figure of a Guam canoe with two booms each with one pair of undercrossed sticks and apparently a vertical lashing between them.

Kubary figures (Pls. LIII, Fig. 20 ; LIV, Figs. 3,5) a paopao canoe from Nukuor and a war canoe from Ponape in the Carolines with a similar attachment of two oblique sticks, the latter has two stay spars, to each of which, where it becomes free from the hull, is fastened a curved spar, apic, which apparently is inserted into the float between the normal attachment and its ends; a similar spar on each side of the two straight booms occurred on a model from Kusaie in the Salem Museum (but one of these apic has entirely disappeared, while the other is represented only by its distal end which is inserted into the float; how they were fastened to the bull is not shown in the photograph), but the booms have a $Y$-stick attachment (these are thus a mixed direct inserted and stick-, and direct inserted and $Y$-stick-attachments); another Kusaie model (Salem Museum) has two pairs of undercrossed sticks for each boom and a curved spar which is lashed to the boom and comes downwards and forwards beneath 
the crossings of the sticks; at Wolea are two vertical sticks on the outer side of each boom, or two sticks on each side, a " bracing spar" slants up from the sticks to the boom (Macmillan Brown, Pl. F, and photograph; Mayer, p. 129). The typical Marshall Islands canoe has two straight booms with one stick (model Salem Museum), two sticks, one on each side (Krämer 1906, p. 416, Fig. 6) or two on each side (model Amsterdam Museum); in the two former three curved booms which arise from the hull on either side of the booms and are lashed to the float (i.e., a mixed direct lashed and stick attachment) see pp. 81, 105, Kubary (Pl. LIV, Fig. 7) indicates a similar arrangement. Folkard (p. 499), as usual, copied Wilkes' drawing (V., p. 49) of a canoe from Drummond I. (Tapiteuea), Gilbert or Kingsmill Islands, with three converging booms and one oblique stick on each side of each boom ; a model in the Cambridge Museum from this group has three vertical sticks, and another model has one pair of undercrossed sticks to each of the three booms.

A simple stick attachment characterizes the tsine canoe of Nissan, an island between New Ireland and Bougainville (Fr., II, Figs. 95, 98 ; Haddon, 1913, Fig. 6) and the three northerly islands of the scattered chain to the east of the Solomons: Nuguria (Thilenius, 1902, p. 61, Pl. III, Fig. 2 ; Fr., II, Figs.106-108), Tauu (Fr., II, Fig. 103), and Nukumanu (Fr., II, p. 300). There is intercourse between these islands and the Gilberts and between the latter and the Polynesian Islands to the south, so it is not surprising that a similar form of attachment is common to them all. Thus we meet with it in Rotuma, Union or Tokelau group, Samoan group, Friendly Islands (Tongan group), and Nieue. The furthest east that I know of it is from Nikuhiva (Marquesas), where d'Urville (I, Pl. I.XI, Fig. 2) illustrates a double canoe with four curved booms and an attachment of four tall vertical sticks. In the Fiji group the sticks consist of two pairs of diverging overcrossed sticks; precisely this arrangement is typical of Torres Straits, where it is associated with a double outrigger, and a two-stick attachment occurs at Batavia River, North-west Queensland, which is remarkably like the Nissan tšne, except that there is a double outrigger.

There is considerable variation in the stick attachments of Northern and Southern Melanesia, which lack of space precludes me from describing. The most common type consists of undercrossed sticks. New Guinea is also characterized by various types of stick attachment; as I am preparing a memoir on this subject I need not further allude to it, except to say that the undercrossed type extends from the east of Geelvink Bay to the Massim District in the extreme south-east, whence probably came the Cape Bedford wangga, which extends along the north-east coast of Queensland from the Flinders Group in the south of Princess Charlotte Bay (lat. $14^{\circ} \mathrm{S}$.) to Cape Grafton (lat. $17^{\circ}$ S.) (Haddon, 1913, p. 617).

The stick attachment may certainly be regarded as an ancient type. Its presence in the Andamans, New Guinea, and Melanesia at first sight might suggest that it was primitively associated with the pygmy, or the taller Oceanic Negroids 
who are usually termed Papuans. Among the Negritos only the Andamanese possess it, and the arrangement of their stick attachment points to a borrowing of the outrigger from the Nicobars. In New Guinea and Melanesia the evidence is strongly against it being part of the old Papuan culture. Very few true Papuan peoples possess an outrigger of any kind, and the names for canoes, and especially for the float, in New Guinea are in the great majority of cases of Austronesian origin We know that during long periods of time many migrations have spread from Indonesia into New Guinea and the Western Pacific, the earlier of which gave rise to that mixed folk whom we term Melanesians, and several migrations of Melanesian peoples have passed into New Guinea carrying with them special types of canoes and outriggers and their distinctive names. The general prevalence of the stick attachment not only in New Guinea and Melanesia, but also in the South Polynesian area, supports the conclusion that its introduction into these regions is due to an early Indonesian influence. On the western border of Indonesia the stick attachment is associated with a single outrigger of several booms in the Andamans, as it is in Melanesia generally. Although the Andamanese are certainly among the most primitive of all existing peoples, there are indications that they have borrowed certain elements of a higher culture, of which the outrigger canoe is one. In the Nicobars the same type of stick attachment is associated with a single outrigger of two booms.

2. The rod attachment appears to be confined to Indonesia (p. 87).

3. The spike attachment is somewhat similar to the foregoing and is characteristic of and I believe peculiar to Geelvink Bay in New Guinea (p. 79); it consists of a thin stick or spike which is driven through the boom and into the float; usually a thin branch extends at right angles from the spike which is lashed on to the boom. Friederici (II, p. 251) says that this attachment is more easily taken to pieces than the Moluccan or Halmaheran, and that the natives hang up the hulls of the canoes in the corridor of the turtle-roofed houses. A spike attachment, combined with a bowed spar which passes along the top of the end of the boom to which it is lashed, the other end being lashed to the float, occurs at Nukutavaka, Paumotu Group (Alexander, pp. 766, 767).

4. The $Y$-shaped stick attachment, though not recorded for Indonesia, occurs widely in the West Pacific and is characteristic of Southern Micronesia, but it appears to be absent from the Mariana (Ladrone) and Marshall groups. In the Pelew Islands each boom may be supported in the fork of one or two of these sticks, it is prevalent in the Carolines and occurs in the Gilberts and at Nauru (Fig. 34). It is lashed to the side of a boom in Liueniua (Ontong Java) and Sikaiana on the eastern flank of the Solomons. In the Liueniua canoe recorded by Friederici the stem of the $Y$ is immersed in the float and there is a lashing in addition, so that superficially it somewhat resembles the $U$-Moluccan attachment. A double overcrossed $Y$-stick occurs in the Loyalty Islands and New Caledonia. Its distribution, therefore, is W.-E., roughly between $10^{\circ} \mathrm{N}$. lat. and the Equator, and roughly N.W.-S.E. from Liueniua 
and Sikaiana to New Caledonia and the Loyalty Islands, but is unrecorded elsewhere (cf. Haddon, 1918, No. 68).

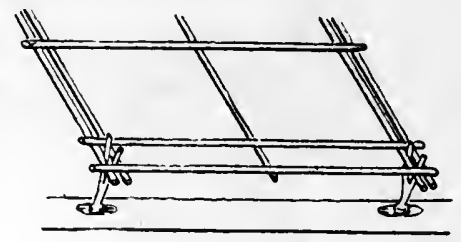

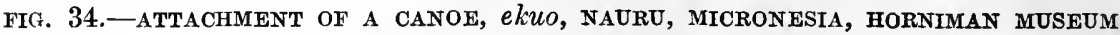
(cf. HAMBRUCH, 1915, fig. 252).

5. The board attachment is typical of Indonesia; in this the boom passes through a board which is inserted into the float (p. 87). A precisely similar arrangement is found on the coast of East Africa, but with a stick or block of wood instead of a board (Haddon, 1918, No. 29). Here it is associated with a double outrigger of two booms. The East African outrigger canoe is universally recognised as having been derived from Indonesia, perhaps, as Horrell suggests, before indirect attachments were lashed to the float in the latter region. The inserted stick attachment is thus confined to marginal areas. A somewhat similar arrangement occurs at Wukuhiva, Marquesas Islands, Alexander (p. 745) figures a canoe with a single outrigger, each of the two booms of which passes through a board, the lower end of which is fastened to the float. According to his description, the ends of the booms "are seized to the perpendicular pieces, or stanchions, the length of which is, as a rule, the distance from the gunwale to the waterline. These pieces are seized to the top side of the float [and not inserted into it as in a true board attachment] . . . The crosspieces [booms], float, and stanchions are braced with withes." A curved brace is present.

6. The Balinese attachment is confined to the Eastern Javan area, but an interesting analogy to it occurs in Funafuti ; Hedley says (p. 286) that the booms "are usually entire, but are sometimes made divisible, spliced in a lock-joint [scarfed] and served. The advantage of detaching the outrigger float from the hull occurs when the canoes are beached and rolled over, the separated hull being more manageable." The Balinese is really a direct inserted attachment, the Funafuti is a direct lashed one, but the occasional unshipping of the ends of the three booms which are permanently attached to the float is a new, and so far as I know, unique, feature. In the Santa Cruz Islands the whole outrigger apparatus may be detachable from the hull.

\section{(b) Attachment Tied to the Float.}

Lashed indirect attachments seem to have ousted the inserted stick attachments throughout the greater part of Indonesia, probably because lashing the attachment to, instead of simply inserting it into, the float was a more secure method of fastening, and at the same time supplied a certain amount of elasticity. 
1. The Halmaheran attachment is confined to Indonesia and the north-west of New Guinea. It varies considerably in form and is widely spread within the area, perhaps because it is adaptable to vessels of large as well as of small size.

2. The Moluccan attachment has a restricted distribution within the area (in my paper in Man, 1918, I erroneously stated on pp. 117, 119 that it occurred in the Sulu archipelago).

3. The double or crossed U-Moluccan attachment occurs among the Barriai, Kobe, and Kilenge on the north coast of the western end of New Britain, at Witu (French Islands) north of New Britain, and among the Nakanai of the north coast of New Britain close to the Gazelle Peninsula, at San Cristoval in the Solomons, and in the Tongan Islands (Haddon, 1918, No. 68). I was misinformed that this attachment is now obsolete in the Tongan Group, as A. G. Mayer gives a photograph of it at Vavau (1916, p. 25).

With the exception of the last, which looks as if it indicated a definite and probably late cultural drift, it is significant that no indirect attachment tied to the float has been reported from Oceania, the inference being that this method developed in Indonesia after all the great migrations had taken place. (The introduction of the mon into the Solomon Islands is, however, of relatively recent date.) If the IndoJavanese ships traded between Java and India we may assume that they also traded in Indonesia, and thus the knowledge of an effective tied attachment should have been known throughout the area. If these ships had a Halmaheran attachment we could assert that the great voyages from Indonesia to Oceania must have taken place long before A.D. 600 , for if this attachment was suitable for ocean-going ships it would surely have been taken into the Pacific and have persisted somewhere there. The entire absence of double canoes from Indonesia and their occurrence in Oceania suggests that these craft belong to an old culture stratum and one which was conten poraneous with the inserted stick attachment, at all events these are at present associated together in Oceania and New Guinea. The Hawaiian type, with its single outrigger and direct lashed attachment, may belong to a special migration.

The persistence of the double outrigger in Indonesia requires some explanation, and it seems to be due to the fact that when provided with an outrigger the dug-out canoe is a very handy, light and stable craft, which is sufficient for the general purposes of an essentially fishing community.

For more extensive trading voyages boats built up of planks were constructed, probably under foreign influence, of the Moluccan orembai type. There can be no doubt that these at first retained the double outrigger, as the korra-korra still do ; Friederici says this is a craft of the construction of a large orembai, but with outriggers (II, p. 237). In Indonesia it was found that the outrigger was unnecessary for large sailing craft and so it was discarded in the orembai. Perhaps the large waga of the Massim district of British New Guinea were derived from vessels of this type before the outrigger was discarded, but in the case of the uaga the outrigger is single. 
Friederici points out that the mŏn (mǒna, mŏr canoe of the Solomon Islands, which is without an outrigger, is constructed in a similar manner to the orembai, indeed, Tasman compared the plank-built mon of South New Ireland to the "corre-corre" of Ternate (Fr., II, p. 238). The mon of the Solomon Lslands have been developed on special lines, and it is open to discussion whether they were derived from an outriggerless plank boat or whether the outriggers were discarded in these islands. Friederici (III, p. 160) says that the mon is not a good sea-going craft (and he says the same is true of the orembai); it is true the Solomon Islanders make long voyages in them, but they are very careful to choose good weather. $\mathrm{He}$ is inclined to attribute its introduction to the second branch of his Alfuran migration and not to the Philippine migration (cf. Man, XVIII, 1918, p. 118). A criterion of the Philippine migration is the term guban (a Sulu archipelago name for a canoe with a double outrigger), but in the West Pacific the double outrigger is retained only in the kop (a variant of guban) of Nissan.

We have now to attempt to determine where the outrigger was invented.

As outrigger canoes are at the present time absent from the mainland of Asia, ${ }^{3}$ except in the Southern Indian area, it is highly improbable that the Southern Mongoloids (Proto-Malays) brought this craft with them, though it is equally probable that earlier immigrants invented the outrigger after they had established themselves in the islands. I have already pointed out (p. 126) that it is very improbable that this invention was due to Negritos or Papuans, and I may here add to these the unprogressive Pre-Dravidians. This leaves us with the Indonesians and that early admixture of Indonesians with the first swarm of Proto-Malays to which the term Alfur has been applied (p. 109), and we may therefore confidently attribute the invention to them. Probably later immigrants adopted the outrigger, but the Orang Malayu always seem to have preferred the outrigger-less craft to which they were accustomed. Indeed it may very well be that this device was due to the inventiveness of the Indonesian, rather than to the Mongoloid, element in the Alfurs.

The early Arab navigators and others who may have come from the Red Sea or Persian Gulf were ignorant of this contrivance, as were also the Chinese navigators. Thus of all the voyagers to the East Indian archipelago, the only possible introducers of an outrigger were Indians, and it is doubtful whether they originally employed it.

In certain large areas of Indonesia outrigger canoes are extremely rare or even absent altogether. The main reason for this absence seems to be a knowledge of the art of building sea-going plank boats, an art which without doubt was introduced

1 Mr. I. H. Evans, of Perak, informs me that his Malay assistant told him that a simple type of double outrigger is occasionally fitted temporarily to Malay boats, generally to the prahu sagor, a small dug-out, when heavily laden. This is the only record known to.me, and it does not invalidate the generalization here made, as the idea may have been borrowed from the islands. Mr. Evans has "seen large tree trunks, whose wood was of greater specific gravity than water, lashed to the sides of prahus, something like outriggers, in bringing them by sea." 
from without, and to which Arabs, Indians, and Chinese have contributed in varying degrees at different times; primitively this art appears to have come from Ancient Egypt. An analogous change has taken place in the Solomon Islands owing to a cultural drift from the Moluccas (Fr., II, p. 161).

An inspection of the map on p. 71 suggests that the present focus of outrigger canoes is in the Moluccas, and it is legitimate to suppose that from Indonesia, if not actually from the Moluccas, migrations took place at various times, each with its special type of canoe or with some partial modification. As a general rule one might expect to find that the earlier types of canoes or of outriggers were those that went furthest, and those that started last would have a more limited distribution; but we must also remember that the later swarms would be more civilised and have a better technical equipment, and thus some of them may have passed over earlier layers and have reached a far destination.

The general distribution of the main types is as follows:-

Marginal: Double outrigger with two booms and a stick or direct lashed attachment; but the double outrigger is also characteristic of the most central area.

Single outrigger with two booms and stick attachments: north coast of British New Guinea and South Polynesian area.

- Single outrigger with several booms and stick attachments : Nicobars, Andamans, parts of New Guinea, Melanesia.

Single outrigger with two booms and a direct lashed attachment : South Indian area and North Polynesian area.

Within the area: Widely distributed, double outrigger with two booms and a direct lashed attachment.

Less distributed, double outrigger with two booms and a Halmaheran attachment.

Most restricted, double outrigger with two booms and a Moluccan attachment.

If we apply the principles enunciated at the beginning of this section we are led to conclude that the above order roughly represents an historical sequence in which it seems evident that, of the indirect attachments, the stick is the oldest and the Moluccan the most recent. There also appears to be a probability that the double outrigger is more ancient than the single, despite its persistence in Indonesia, a fact which does not fit in with the foregoing argument.

\section{Bibliography.}

Adriani, N., and Kruyt, A. C.-De Barée-sprekende Toradjàs van Midden-Celebes. Platen en Kaarten. s' Gravenhage, 1912.

Alexander; A. B.- "Notes on the boats, etc. of the South Sea Islands." U.S. Com. of Fish and Fisheries. Part xxvii, Report of the Commissioner for 1901, Washington, 1902. 
Anson, G.-A Voyage Round the World. 1748.

Baessler.-Internat. Arch. f. Ethnogr., IV, 1891.

Beeckman, D.-A Voyage to and from the Island of Borneo. 1718.

Bickmore, A. S.-Travels in the East Indian Archipelago. 1868.

Brenner, J. F. von.-Besuch bei den Kannibalen Sumatras. Würzburg, 1894.

Brown, J. Macmillan.-Man., XIV, 1914, No. 4.3.

Bry, J. T. de.-India Orientalis, Pars V. (Quinta Pars, Indice Orientalis.) Francofurti, 1601. Burbidge, F. W. T.-The Gardens of the Sun. 1880.

Christian, F. W.-Eastern Pacific Lands : Tahiti and the Marquesas 1slands. 1910.

Clercq, F. S. A. de, and Schmeltz, J. D. E.-Ethnographische Beschrijving van de West-noordkust. van Nederlandsch Nieuw-Guinea. Leiden, 1893.

Dumont d'Urville, J. S. C.-Voyage pittoresque autour du Monde. Paris, 1834.

Edye, J.-Journ. Roy. Asiat. Soc., I. London, 1834.

Ellis, W.-Polynesian Researches. 2nd Edit., 1831.

Fischer, H. W.-Katalog Ethnogr. Reichsmuseums. X., Mittel-Sumatra (Sumaitra, III). Leiden, 1916.

Folkard, H. C.-The Sailing Boat. 5th Edit., 1901.

Forbes, H. O.-A Naturalist's Wanderings in the Eastern Archipelago. 1885.

Forrest, T.-A Voyage to New Guinea and the Moluccas, etc., during the years 1774, 1775 and 1776. London, 1779.

- Voyage aux Moluques et à la Nouvelle Guinée. Paris, 1780.

Friederici, G. (referred to as Fr.).-Wissenschaftliche Ergebnisse einer amtlichen Forschungsreise nach dem Bismarck-Archipel im Jahre 1908.

II.—“ Beiträge zur Völker- und Sprachenkunde von Deutsch-Neuguinea." Mitteil.aus den Deutsch. Schutzgeb., Ergänzungsheft Nr. 5, 1912.

III._-" Untersuchungen über eine melanesische Wanderstrasse." Ibid. $\quad$ Erg.-heft, Nr. 7 1913.

Fritsch, G.-Globus, XCI., 1907.

Giglioli, H. H.-Int. Arch. für Ethnogr., VI., 1893.

Gomes, E. H.-Seventeen Years among the Sea Dyaks of Borneo. 1911.

Graafland, N.-De Minahassa. Haarlem, 1898.

Graebner, F.-Zeitschr. f. Ethnologie, XXXVII, 1905.

- Anthropos, IV., 1909.

Grubauer, A.-Unter Kopfjägern in Central-Celebes. ' Leipzig, 1913.

Guillemard, F. H. H.-The Cruise of the Marchesa. 2nd Edit., 1889.

—_ "Australasia." II. Standford's Compendium of Geography. 1894.

- G.-Photographs in the possession of Dr. Guillemard taken when on the cruise of the "Marchesa," 1881-1884.

Haddon, A. C.-The Wanderings of Peoples. Cambridge, 1911 ; 2nd Edit., 1920.

— "The outrigger canoes of Torres Straits and North Queensland." Essays and Studies presented to William Ridgeway. Cambridge, 1913.

__ Man, XVIII, 1918, Nos. 29, 68.

Hambruch, P.-Ergebnisse d. Südsee Exped. 1908-1910, II, Ethnogr. B. Mikronesien Bd. 1 Nauru 2 Halbband. Hamburg, 1915.

Havell, E. B.-Indian Sculpture and Painting. 1908.

Hedley, C.-The Atoll of Funafuti. Memoir III. Australian Museum, Sydney, 1897.

Hickson, S. J.-A Naturalist in the Celebes. 1889.

— Proc. Camb. Antiqu. Soc., VII (N.S., I.), 1891 (1893).

Hornell, J.-Man, XIX, 1919, No. 55.

Hose, C., and MoDougall, W.-The Pagan Tribes of Borneo. 2 Vols. 1912.

Juynboll, H. H.-Katalog Ethnogr. Reichsmuseums. XI, Java (II.). Leiden, 1916.

Keane, A. H.-Man Prst and Present. Cambridge, 1899 ; Revised Edition, 1920. 
Kloss, C. B.-In the Andamans and Nicobars. 1903.

Krämer, A.-Die Samoa-inseln. II. Stuttgart, 1903.

- Hawaii, Ostmiloronesien und Samoa. 1908.

- Kor. Blatt d. Deutsch Ges. f. Anth. LXIII. 1911.

Krause, F.-Jahrbuch d. stïll. Mus. f. Vïlkerkunde zu Leipzig. I. 1908 (1907).

Krieger, M.-Neu-Guinea. Berlin, 1899.

Kubary, J. S. - Ethnographische Beitrïge zur Kentniss des Karolinen Archipelo. Leiden, 1896.

Ktikenthal, W.- "Forschungsreise in den Molukken und in Borneo." Abhandl. d. Sencken bergischen naturfors. Gesellschaft, XXII. Frankfurt-a-M., 1896.

L., G. M. A. W.-Premier Livre de l'Histoire de la Navigation aux Indes orientales, elc. C. Nicolas Amstelredam, 1598.

Landor, A. H. Savage.-The Gems of the East. 1904.

Lane-Fox (Pitt-Rivers), A. H.-Journ. Anthrop. Inst., IV, 1875, p. 399 ; reprinted in Evolution of Culture by Pitt-Rivers, A. L. F., Oxford, 1905. Journ. Anthrop. Inst., VII, 1878, p. 434.

Langen, H. G.-Key-oder Kii-Inseln des O.I. Archipel. Wien, 1902.

Leemans, C.-Bốró-Boedoer, Leiden, 1873 ; Bôró-Boudour (French translation). Leide, 1874.

Linschoten (Lintscotus), J. H. van.-in Bry, J. T. de, India Orientalis, Pars III (Tertia Pars. Indice Orientalis). Francofurti, 1601.

Mager, H.-Le Monde polynésien. Paris, 1902.

Man, E. H. Journ. Anthrop. Inst., XI, 1882, p. 268 ; XII, 1883, p. 117 ; XV, 1886, p. 428.

Martin, K.-Reisen in den Molukken. Leiden, 1894 ; Geologische Theil, 1903.

Mayer, A. G._-" The Islands of the Mid-Pacific." The Scientific Monthly. II. New York, 1916.

Meyer, A. B., and Richter, 0.- "Geisterfallen im Ostindisohen Archipele." Abhandl. u. Ber. des Königl. Zool. u. Anth.-Eth. Museums zu Dresden. Bd. X. No. 6. Ethnograph. Miszellen. II. Berlin, 1903.

Modigliani, E.-Un Viaggio a Nias. Milan, 1890.

- L'Isola della Donne. Milan, 1894.

Mouat, F. J.-Adventures and Researches among the Andaman Islanders. 1863.

Müller, W.-Baessler-Arch., II, 1912, p. 235.

—- Yap, Ergebnisse der Siidsee-Expedition, 1908-1910. Hamburg, 1917.

Munday, R.-Narrative of Events in Borneo and Celebes from the Journal of James Brooke. 1848.

Nicolas, C. [Printer].- Le Second Livre Journal ou Comptoir, contenant le vray Discours et Narration historique du Voiage faict par les hiuct Navires, etc. Amsterdam, 1601.

Nieuenhuis, A. W.-Quer durch Borneo. Leiden, 1904-07.

Pallander, E.-The Log of an Island Wanderer. 1901.

Partington, J. Edge, and Heape, C.-Ethnographical Album of the Pacific Islands. I. Manohester, 1890.

Perouse, Atlas du Voyage de la-London, 1798.

Perry, W. J.-The Megalithic Culture of Indonesia. Manchester and London, 1918.

Pflüger, A.-Smaragd-inseln der Sïdsee: Bonn., n.d.

Pritchett, R. T.-Pen and Pencil Sketches of Shipping and Craft round the World. 1899.

Radhakumud Nookerji.-Indian Shipping. London, 1912.

Riedel, G. F.-De sluik-en kroesharige rassen, etc. s' Gravenhage, 1886.

Rivers, W. H. R.-The History of Melanesian Society. Cambridge, 1914.

Rosenberg, H. von.-Der Malayische Archipel. Leipzig, 1878.

- Ini. Arch. für Ethnogr., I., 1888, p. 218.

Roth, W. E.- "North Queensland Ethnography." Bull. 14. Records of the Australian Museum, VIII. Sydney, 1910.

Roth, H. Ling.-Crozet's Voyage to Tasmania, New Zealand, etc. 1891.

Safford, W. E.-“"Guam and its People." Smithsonian Report, 1902 (1903).

Sarasin, P. and F.-Reisen in Celebes. Wiesbaden, 1905.

Smith, V. A.-The early History of India, 3rd Edit. Oxford, 1914. 
Svoboda, W.-Int. Arch. für Ethnogr., V, 1892 ; VI, 1893, 1.

Thilenius, G.-_" Ethnograph. Ergebnisse aus Melanesien 1. Theil, Die polynesischen Inseln an der Ostgrenze Melanesiens." Nova Acta. Abh. der Kaiserl. Leop.-Carol. Deutsch. Akad. der Naturforscher, Bd. LXXX, Nr. 1. Halle, 1902.

Valentijn, F.-Oud en Nieuw Oost-Indiën, IV. 1726.

Vojnich, O.-The Island World of the Pacific. Budapest, 1909.

Wallace, A. R.-The Malay Archipelago. 1869.

Weule, K.-Leitfaden der Vijlkerkunde. Leipzig, 1912.

Wilkes, C.-Narrative of the United States Exploring Expeditinn. London and Philadelphia, 1845.

\section{Adpenda.}

Friederici, G.-Malaio-Polynesische Wanderungen. Leipzig, 1914 ;

Verhandl.des XIX Deutschen Geographentages zu Strassburg i. Eils. 1914. Berlin, 1915.

These reached me after my paper was in print; the earlier of these two papers is the more valuable as there are copious references. The author believes that the MalayoPolynesian migrations left Indonesia before the Hindu influence there, and took place in the second and fourth centuries A.D., and that the Sumatrian migration to Madagascar took place in the tenth century A.D. He suggests that the Malayo-Polynesian migrations were originally made on rafts of three beams, and that canoes with double outriggers were developed from them ; the reduction of these to single outriggers" "is quite a natural process" ; the double canoe arose from the latter by the float being increased in size and hollowed out.

Hornell, J._"The Origins and Ethnological Significance of Indian Boat Designs." Mem. Asiatic Soc. of Bengal, VII, p. 139, Calcutta, 1920.

This is a very valuable monograph. Hornell discusses the Javanese ships of the Borobudur sculptures and gives new drawings of my Figs. 25 and 28 which clear up certain points ; both have biped masts, the latter having rungs between the limbs, and the three booms of this ship are distinctly curved and pass between the two elements of the float.

"Les Pirogues à balancier de Madagascar et de l'Afrique orientale." La Géographie, XXXIV. Paris, 1920, p. 1

"Madagascar and East Africa : Canoes." Man, 1920, No. 67.

These excellent papers have appeared too late for me to refer to them, the former is the longer and has more illustrations. Hornell shows that the following varieties occur on the west coast of Madagascar, all with two booms :-

1. Direct inserted in a model of a sailing boat with an ordinary float on one side, and on the other the boonis carry a reduced float which evidently serves as an outlayer.

2. Double outrigger with a small board ("peg stanchion") attachments to the two floats.

3. Single outrigger with similar attachments, the booms on the other side being tied to a light bamboo spar to form an outlayer.

4. - do.--do.-, but only the fore boom is prolonged on the other side, it serves to extend the starboard sheet.

In the sixteenth and seventeenth centuries all the canoes appear to have had double outriggers, by the middle of the nineteenth century both forms occurred, now none but single ones occur.

The attachment in Madagascar is always vertical, as it is at Lamu, but in the other East African canoes it is oblique and the flat board is similarly horizontal or canted. Hornell rightly observes that these facts justify his previous conclusion that the outrigger canoes of Madagascar and East Africa are derived directly from Javanese [or at all events Indonesian] types. He points out that "In their consistently double form, the African varieties have retained a primitive structure almost entirely lost in present-day Madagascar outriggers" and that "the Lamu variety having vertical stanchions approaches most closely to the Marlagascar form."

I may add that I have just come across a very badly drawn illustration of a canoe from Mohelia, with a double outrigger : each pair of the two divergent booms appear to be directly connected with its float. T. H. [Herbert] Esquier, A Relation of Some Yeares Travaile, Begunne Anno 626 ; London 1634.

[Reprinted from the Journal of the Royal Anthropological Institute, Vol. $L$, January-June, 1920.] 



\section{ROYAL ANTHROPOLGECAL INSTITUTE OF GREAT BRITAIN AND IRELAND.}

This Institute was established in 1871 by the amalgamation of the older Anthropological Society and Ethnological Society. It Las for its object the promotion of the Science of Mankind-Authropology-by the accumulation of observations bearing on man's past history and present statevin all-parts of the globe. It investigates, in a rigorously exact manner, everything that can throw light upon the laws of man's nature: his origin, history, and capabilities of progressive development and civilization. It studies him structurally and psychologically, under the several types in which he is found in various regions; and comparatively, in relation to the rest of the animal kingdom. The ultimate object of the Institute, therefore, is to build up a Science of Man on a basis of well-ascertained fact, and logically deduced inference. As means to this end, the Council of the Institute has adopted a plan of operations, the principal heads of which are as follow :-

1. Meetings for the reading of papers and for discuesion of anthropolngical questious.

2. The issue of \& Tournal containing Reports of the Proceedings at the Meetings, with other matters of anthropological interest.

3. The appointment of Local Correspondents in all parts of the frorld to collect information, and to aid the Institutio in its operations.

4. The maintenance of a libracy, which contains sets of all the principal Anthropological Journals published in the United Kingdom or elsewhere, besides a large and valuable collection of books of reference, travels and researches, an extensive collection of photograplis and lantern slides, and much unpublished material for the use of students of Anthropology. Fellows residing in the country, at well as in London; can borrow books from the library.

5. The appointment of Committees to conduct special investigations, as occasion offers, in the various branches of Anthropology.

6. Co-operation with the British Association for the Advancement of Science, and with foreign scientific societies in anthropological investigations ; co-operation with individuals and institutions in aid of explorations and in the establishment of local centres of anthropological study; and generally, the stimulation of individual and local efforts to further the objects of the Institute.

The annual subscription is Two Guiness, which is due on election (unless such election takes place in the month of November or December) and on the Ist of January in each succeeding year. A Member may at any time compound his future subscriptions by the payment of $£ 3110$ s.

Persons who wish to become Fellows of the Institute are requested to communicate with the Secretary, 50, Great Russell Street, W.C. 
Haddon, Alfrea Cort, $1855-1940$ The outriggers of

. 2

H34

Indonesian canoes. Royal

Anthropological

Institute of Great Britain and Ireland $([\mathrm{n} \cdot 3 \cdot])$

PLEASE DO NOT REMOVE CARDS OR SLIPS FROM THIS POCKET

UNIVERSITY OF TORONTO LIBRARY 
